UNIVERSIDADE DE SÃO PAULO

INSTITUTO DE QUÍMICA DE SÃO CARLOS

\title{
DETERMINAÇÃO DE CIANOTOXINAS EM AMOSTRAS DE FLORAÇÕES DE CIANOBACTÉRIAS COLETADAS EM PESQUE-PAGUES E PISCICULTURAS SITUADAS NA REGIÃO DO ALTO MOGI
}

\author{
Fabiana Martins de Andrade
}

Dissertação apresentada ao Instituto de Química de São Carlos, Universidade de São Paulo, como parte dos quesitos para a obtenção do título de Mestre em Ciências (Química Analítica)

Orientadora: Dra. Eny Maria Vieira

São Carlos

2009 
Aos meus pais e toda a minha família por todo incentivo, amor e carinho. 


\section{AGRADECIMENTOS}

À Deus por ter me enviado para uma família tão perfeita, ter me concedido saúde e paz para poder concluir esse trabalho;

À Profa. Dra Eny Maria Vieira pela orientação, dedicação e por todas as oportunidades;

Ao Instituto de Química de São Carlos pelo apoio institucional e infraestrutura necessária a realização deste trabalho;

A todos os integrantes do grupo, principalmente à Wilma Montagnolli, Ricardo Luvizotto e Renata de Oliveira Pereira por todo o auxílio, companheirismo, descontração e ajuda no trabalho realizado;

Às bibliotecárias do IQSC pelo auxilio nas referências bibliográficas;

À todos os funcionários da CAQUI, em especial ao Dr. Paulo Cordeiro e ao Dr. Mauro Fernandes, pelo apoio e solicitude nas análises cromatográficas e espectrofotométricas;

Às pesquisadoras Maria Angélica e Márcia Eller pela parceria, disposição de materiais e também pela amizade;

Às minhas amigas Daniela, Franciani, Janaína, Juliana e Marília pelo apoio e carinho em todos os momentos. 


\section{RESUMO}

O crescimento acelerado da aqüicultura no estado de São Paulo, ou seja, a implantação de pesque-pagues e pisciculturas pode estar causando uma série de problemas ambientais. A contribuição para o processo de eutrofização é uma das conseqüências desses empreendimentos, pois tanto os tanques utilizados na piscicultura como os afluentes em torno desses estabelecimentos, estão sendo eutrofizados pelo excesso de nutrientes. Uma das conseqüências da eutrofização é o aparecimento de florações de cianobactérias, e a principal preocupação está nas toxinas liberadas por estas cianobactérias, que se ingeridas pelos seres humanos e animais, podem causar efeitos de intoxicação, como fraqueza, cefaléia, vômito e dependendo da concentração ingerida pode levar à morte. Desta forma é necessário que haja um programa de controle da qualidade da água dos tanques e reservatórios e também dos peixes que ali são criados, pois florações de cianobactérias vêm sendo encontradas em diversos corpos d'água. Este estudo teve como foco a determinação da cianotoxina microcistina-LR, empregando técnicas como a extração em fase sólida e a cromatografia líquida para a detecção e quantificação da microcistina-LR em amostras de florações de cianobactérias. Os testes feitos com a extração em fase sólida demonstraram que esse procedimento não se faz necessário para todas as amostras, pois houve casos em que não se obteve diferença nos picos interferentes mais próximos ao tempo de retenção do analito de estudo. Como as matrizes desse tipo de amostras são muito complexas e variam muito conforme o meio em que se encontram, recomenda-se que sejam avaliados caso à caso a necessidade de se promover a extração em fase sólida, pois o mesmo é um processo que demanda um tempo maior de análise e conseqüente aumento nos custos. Foi determinado e validado um método cromatográfico considerado capaz de fornecer dados reproduzíveis e confiáveis, por meio de testes de seletividade, limite de detecção e de quantificação, linearidade, precisão, exatidão e recuperação, conforme critérios de aceitação da Resolução n 899 de 2003, da ANVISA. O limite de detecção do método ficou estipulado em 0,1 $\mu \mathrm{g} \mathrm{mL}^{-1}$, e o limite inferior de quantificação em $0,5 \mu \mathrm{g} \mathrm{mL}^{-1}$, determinados conforme a relação sinal-ruído proposta pelo Guia de Validação de Métodos Bioanalíticos da ANVISA. A quantificação da microcistina-LR foi feita utilizando o método de superposição de matriz, que minimiza e/ou compensa o efeito de matriz ou de possíveis interferentes presentes na amostra, e a curva analítica obtida y $=1,5888+$ 21,849 x, com um coeficiente de correlação de 0,997 mostra uma boa linearidade. Foram analisadas amostras de florações de cianobactérias, coletadas em pesquepagues e pisciculturas situadas na região do Alto Mogi (subdivisão da bacia do Mogi Guaçu), conforme o método de extração e análise estudado. 


\begin{abstract}
The rapid growth of aquaculture in the state of São Paulo may be causing a number of environmental problems. The contribution to the eutrophication process is among the consequences of these undertakings, given that the tanks used in fish farming as well as the changes around these establishments are becoming eutrophic systems due to excessive nutrients. A frequent consequence of eutrophication in waters is the massive development of cyanobacteria.

The occurrence of these blooms induces severe problems, as Microcystis aeruginosa, the most widespread distributed cyanobacteria, which can produce microcystin-LR. Toxic effects of MC have been described in liver, lungs, stomach, and intestine. Deaths in wildlife, livestock and human beings were also associated with microcystin exposition, which can occur directly by ingestion, inhalation, contact, intravenous inoculation of contaminated water (hemodialysis) or indirectly, by the consumption of animals, as fish and mollusks, the major ingestors of cyanobacteria and its toxins. Thus we need a program to control the quality of water tanks and reservoirs and also the fish breeded there, as cyanobacteria blooms have been found in various water bodies.

This study focused on the determination of the cyanotoxins microcystin-LR, using techniques such as solid phase extraction and liquid chromatography for the detection and quantification of microcystin-LR in samples of cyanobacteria blooms. Tests performed with solid phase extraction showed that this procedure is not necessary for all the samples because there were cases where no difference was obtained in interfering peaks near the retention time of the analyte studied. As the parent of such samples are very complex and vary greatly, because the extracts contained too much coextrated material that interfered in the LC-UV detection, and depending on the way in which it is recommended to be assessed, case by case, the solid phase extraction needs to be promoted, because it is a process that demands a longer period of analysis and consequently an increase in costs. A liquid chromatography method was established and validated, which is deemed capable of providing reproducible and reliable data, by testing for selectivity, limit of detection and quantification, linearity, precision, accuracy and recovery, in accordance with the acceptance criteria of Resolution No. 899 of 2003 of ANVISA. The detection limit of the method was set at $0.1 \mu \mathrm{g} \mathrm{mL}^{-1}$, and the lower limit of quantification at $0.5 \mu \mathrm{g} \mathrm{mL}^{-1}$ determined according to the signal to noise ratio proposed by the Validation Guide of Bioanalytical Methods, ANVISA. Quantification of microcystin-LR was performed using the matrix-matched method, which minimizes and/or offsets the effect of possible matrix interference or present in the sample. The analytical curve obtained $y$ $=1.5888+21.849 \mathrm{x}$, with a coefficient of correlation of 0.997 shows a good linearity. Real aquaculture samples were analyzed that were detected and quantified according to the method developed.
\end{abstract}

Key words: Microcystis aeruginosa, microcystin, cyanobacterial toxins, hepatotoxin 


\section{Lista de Figuras}

Figura 1: Estrutura cíclica geral das microcistinas onde $X$ e $Z$ representam os dois Laminoácidos variáveis e R1 e R2 são os locais de possíveis metilações.

Figura 2: Estrutura da microcistina-LR (Rivasseau et al., 1997)....................... 20

Figura 3: Lançamento de efluente contendo cianobactérias (água verde, em primeiro plano) num curso d'água originalmente sem cianobactéria (ao fundo, água de montante escura pelo húmus). As cianobactérias devem ser removidas antes deste descarte.

Figura 4: Cartucho típico empregado em extração em fase sólida (SPE).

Figura 5: Bacias hidrográficas do estado de São Paulo

Figura 6: Localização da bacia hidrográfica do Mogi Guaçu (adaptada do Relatório Zero CBH-MOGI, Comitê de Bacia Hidrográfica do Mogi Guaçu, 1999).

Figura 7: Fluxograma das etapas envolvidas na extração da microcistina-LR de amostras de florações

Figura 8: Etapas da extração em fase sólida.

Figura 9: Foto ilustrativa do equipamento utilizado na validação do método. Marca: Agilent, Série - 1200 .

Figura 10: Foto ilustrativa do sistema utilizado na parte inicial desse estudo. Marca: Shimadzu, Modelo CBM -10 A. Equipamento instalado na CAQUI (Central de Análises Químicas Instrumentais)

Figura 11: Espectro de UV do padrão da microcistina-LR. Espectrofotômetro Ultravioleta / Visível - Infravermelho Próximo (UV/Vis-NIR), Varian/Cary $5 \mathrm{G}$.

Figura 12: Cromatograma do padrão da microcistina-LR. Comprimento de onda $238 \mathrm{~nm}$, fase móvel 40:60 (Acetato de amônia 20 mM, pH 5 : Metanol), coluna C18, da marca Rexchrom S5-100-ODS, com tamanho das partículas de $5 \mu \mathrm{m}, 150 \mathrm{~mm}$ de comprimento e 4,6 mm de diâmetro interno, volume de injeção de $20 \mu \mathrm{L}$ e fluxo de $1 \mathrm{~mL}$ min-1. Cromatógrafo Líquido da Shimadzu CBM-10 A......

Figura 13: Cromatograma do padrão de microcistina-LR. Fase móvel metanol e ácido acético 0,1\% (55:45), coluna C18, da marca Rexchrom S5-100-ODS, com tamanho das partículas de $5 \mu \mathrm{m}, 150 \mathrm{~mm}$ de comprimento e $4,6 \mathrm{~mm}$ de diâmetro interno, volume de injeção de $20 \mu \mathrm{L}$ e fluxo de $1 \mathrm{~mL}$ min-1. Cromatógrafo Líquido da Shimadzu CBM-10 A

Figura 14: Cromatograma do padrão da microcistina-LR, obtido conforme o gradiente descrito anteriormente, com os solventes metanol e ácido acético $0,1 \%$ como fase B e A respectivamente. Coluna C18, da marca Rexchrom S5-100-ODS, com tamanho das partículas de $5 \mu \mathrm{m}, 150 \mathrm{~mm}$ de comprimento e 4,6 mm de diâmetro interno, comprimento de onda de $238 \mathrm{~nm}$, volume de injeção de $20 \mu \mathrm{L}$ e fluxo de $1 \mathrm{~mL}$ min1. Cromatógrafo Líquido da Shimadzu CBM-10 A..... 
Figura 15: Cromatograma do padrão da microcistina-LR, obtido conforme o gradiente descrito na Tabela, coluna Zorbax SB-C18, Agilent, com tamanho de partícula de 5um, $250 \mathrm{~mm}$ de comprimento e $4,6 \mathrm{~mm}$ de diâmetro interno, volume de injeção de $20 \mu \mathrm{L}$, comprimento de onda de $238 \mathrm{~nm}$ e fluxo de $1,5 \mathrm{~mL} \min -1$. Cromatógrafo Líquido da Agilent Technologies

Figura 16: Cromatograma do padrão da microcistina-LR, obtido conforme o gradiente descrito na Tabela , coluna Nucleosil C18, com tamanho de partícula de $5 \mathrm{um}, 250 \mathrm{~mm}$ de comprimento e 4,6mm de diâmetro interno, volume de injeção de $20 \mu \mathrm{L}$, comprimento de onda de $238 \mathrm{~nm}$ e fluxo de $1,5 \mathrm{~mL}$ min-1. Cromatógrafo Líquido da Agilent Technologies. Robustez - Troca de coluna.

Figura 17: Espectros de UV do padrão da microcistina-LR obtido por meio do software Chemstation. A sobreposição do espectro do padrão com o espectro de um pico da amostra que saiu com o mesmo tempo de retenção do padrão, pode ser considerada uma contraprova para a indicativa da presença da toxina microcistinaLR. Absorção máxima em $238 \mathrm{~nm}$

Figura 18: Cromatograma do extrato de floração de cianobactéria, filtrada em um filtro de poro de $0,45 \mu \mathrm{m}$. Coluna C18, da marca Rexchrom S5-100-ODS, com tamanho das partículas de $5 \mu \mathrm{m}, 150 \mathrm{~mm}$ de comprimento e $4,6 \mathrm{~mm}$ de diâmetro interno, comprimento de onda de $238 \mathrm{~nm}$, volume de injeção de $20 \mu \mathrm{L}$ e fluxo de $1 \mathrm{~mL} \min -1$. Cromatógrafo Líquido da Shimadzu CBM-10 A. Gradiente utilizando metanol: ácido acético $0,1 \%$ na proporção de $35: 65(\mathrm{v} / \mathrm{v})$, sendo que aumentou-se a proporção do metanol até 98:2 durante 35 minutos, permanecendo nessa condição por 5 minutos. O retorno à fase inicial $(35: 65)$ foi de 15 minutos, e por mais cinco minutos permaneceu nessa proporção para um total equilíbrio da fase móvel, tempo total de análise de $60 \mathrm{~min}$

Figura 19: Cromatograma do extrato de floração de cianobactéria, percolada por um cartucho adsorvente de C18 (SPE). Coluna C18, da marca Rexchrom S5-100-ODS, com tamanho das partículas de $5 \mu \mathrm{m}, 150 \mathrm{~mm}$ de comprimento e $4,6 \mathrm{~mm}$ de diâmetro interno, comprimento de onda de $238 \mathrm{~nm}$, volume de injeção de $20 \mu \mathrm{L}$ e fluxo de $1 \mathrm{~mL}$ min-1. Cromatógrafo Líquido da Shimadzu CBM-10 A. Gradiente utilizando metanol: ácido acético $0,1 \%$ na proporção de $35: 65(\mathrm{v} / \mathrm{v})$, sendo que aumentou-se a proporção do metanol até $98: 2$ durante 35 minutos, permanecendo nessa condição por 5 minutos. O retorno à fase inicial (35:65) foi de 15 minutos, e por mais cinco minutos permaneceu nessa proporção para um total equilíbrio da fase móvel, tempo total de análise de 60 $\min$

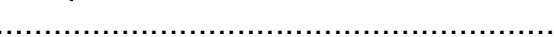

Figura 20: Cromatograma da injeção de 20 uL de diluente, metanol acidificado com TFA (pH 2). Obtido conforme o gradiente descrito na Tabela 5, coluna Nucleosil C18, com tamanho de partícula de $5 \mathrm{um}, 250 \mathrm{~mm}$ de comprimento e $4,6 \mathrm{~mm}$ de diâmetro interno, comprimento de onda de $238 \mathrm{~nm}$ e fluxo de $1,5 \mathrm{~mL} \min$ 
Figura 21: Cromatograma da injeção de 20 uL da matriz (amostra de floração de cianobactérias que não foi detectada a microcistina-LR). Obtido conforme o gradiente descrito na Tabela 5, coluna Nucleosil C18, com tamanho de partícula de 5 um, $250 \mathrm{~mm}$ de comprimento e $4,6 \mathrm{~mm}$ de diâmetro interno, comprimento de onda de 238 e fluxo de 1,5 mL/ $\min$

Figura 22: Cromatograma do padrão da microcistina-LR na concentração de $0,1 \mu \mathrm{g} \mathrm{mL}-1$, limite de detecção (LD), determinado pela razão sinal-ruído. Para o cálculo do ruído da linha de base, foi considerado o intervalo de 1 minuto, antes e após o tempo de retenção do padrão, de 17,6 minutos.

Figura 23: Cromatograma do padrão da microcistina-LR, $0,5 \mu \mathrm{g} \mathrm{mL}-1$, LIQ (Limite Inferior de Quantificação). Para o cálculo do ruído da linha de base, foi considerado o intervalo de 1 minuto, antes e após o tempo de retenção do padrão de 17,1 $\min$.

Figura 24: Cromatograma do padrão da microcistina-LR. $O$ tempo de retenção da microcistina-LR com o fluxo da fase móvel em $1,7 \mathrm{~mL}$ minuto-1 é de aproximadamente 16,9 minutos. Teste de Robustez - Fluxo acima.

Figura 25: Cromatograma do padrão da microcistina-LR. O tempo de retenção da microcistina-LR, com o fluxo da fase móvel em 1,2mL minuto-1 é de aproximadamente 18,6 minutos. Teste de Robustez- Fluxo abaixo

Figura 26: Cromatograma do padrão da microcistina-LR. O tempo de retenção da microcistina-LR quando a proporção de solvente orgânico é aumentada em $5 \%$ é de 12,5 minutos. Proporções do gradiente vide Tabela 10. Teste de Robustez Orgânico Acima.

Figura 27: Cromatograma do padrão da microcistina-LR. O tempo de retenção da microcistina-LR quando a proporção de solvente orgânico é diminuida em $5 \%$ é de 21,7 minutos. Proporções do gradiente vide Tabela 11. Teste de Robustez Orgânico Abaixo.

Figura 28 Curva analítica, respostas das áreas dos picos das soluções-padrão da microcistina-LR versus concentração (Método de Superposição de Matriz)

Figura 29: Curva analítica, respostas das alturas dos picos das soluções-padrão da microcistina-LR versus concentração (Método de Superposição de Matriz)

Figura 30: Fotografia do tanque do estabelecimento A com a presença de florações de cianobactérias. Fotografia tirada em setembro de 2007, por Eny Maria Vieira.

Figura31: Cromatograma do extrato de floração de cianobactéria do estabelecimento $A$, coletado em outubro de 2006. Obtido conforme o gradiente descrito na Tabela 2, coluna Nucleosil C18, com tamanho de partícula de $5 \mathrm{um}, 250 \mathrm{~mm}$ de comprimento e 4,6 mm de diâmetro interno, comprimento de onda de $238 \mathrm{~nm}$ e fluxo de $1,5 \mathrm{~mL}$ min-1. Um pico com o mesmo tempo de retenção da microcistinaLR foi encontrado. 
Figura 32: Cromatograma do extrato de floração de cianobactéria do estabelecimento $B$, coletado em outubro de 2006. Obtido conforme o gradiente descrito na Tabela 2, coluna Nucleosil C18, com tamanho de partícula de $5 \mathrm{um}, 250 \mathrm{~mm}$ de comprimento e 4,6 mm de diâmetro interno, comprimento de onda de $238 \mathrm{~nm}$ e fluxo de $1,5 \mathrm{~mL}$ min-1. Um pico com o mesmo tempo de retenção da microcistinaLR foi encontrado

Figura 33: Cromatograma do extrato de floração de cianobactéria do estabelecimento $D$, coletado em maio de 2007. Obtido conforme o gradiente descrito na Tabela 2, coluna Nucleosil C18, com tamanho de partícula de $5 \mathrm{um}, 250 \mathrm{~mm}$ de comprimento e 4,6 mm de diâmetro interno, comprimento de onda de $238 \mathrm{~nm}$ e fluxo de $1,5 \mathrm{~mL}$ min-1. Um pico com o mesmo tempo de retenção da microcistinaLR foi encontrado

Figura 34: Cromatograma do extrato de floração de cianobactéria do estabelecimento C, coletado em maio de 2007. Obtido conforme o gradiente descrito na Tabela 2, coluna Nucleosil C18, com tamanho de partícula de $5 \mathrm{um}, 250 \mathrm{~mm}$ de comprimento e 4,6 mm de diâmetro interno, comprimento de onda de $238 \mathrm{~nm}$ e fluxo de $1,5 \mathrm{~mL}$ min-1. Um pico com o mesmo tempo de retenção da microcistinaLR foi encontrado.

Figura 35: Cromatograma do extrato de floração de cianobactéria do estabelecimento $A$, coletado em setembro de 2007. Obtido conforme o gradiente descrito na Tabela 2, coluna Nucleosil C18, com tamanho de partícula de $5 \mathrm{um}, 250 \mathrm{~mm}$ de comprimento e 4,6 mm de diâmetro interno, comprimento de onda de $238 \mathrm{~nm}$ e fluxo de $1,5 \mathrm{~mL}$ min-1. Um pico com o mesmo tempo de retenção da microcistinaLR foi encontrado.

Figura 36: Cromatograma do extrato de floração de cianobactéria do estabelecimento C, coletado em setembro de 2007. Obtido conforme o gradiente descrito na Tabela 2, coluna Nucleosil C18, com tamanho de partícula de $5 \mathrm{um}, 250 \mathrm{~mm}$ de comprimento e 4,6 mm de diâmetro interno, comprimento de onda de $238 \mathrm{~nm}$ e fluxo de $1,5 \mathrm{~mL}$ min-1. Um pico com o mesmo tempo de retenção da microcistinaLR foi encontrado

Figura 37: Cromatograma do extrato de floração de cianobactéria do estabelecimento E, coletado em janeiro de 2008. Obtido conforme o gradiente descrito na Tabela 2, coluna Nucleosil C18, com tamanho de partícula de $5 \mathrm{um}, 250 \mathrm{~mm}$ de comprimento e 4,6 mm de diâmetro interno, comprimento de onda de $238 \mathrm{~nm}$ e fluxo de $1,5 \mathrm{~mL}$ min-1. Não foi encontrado nenhum pico com o mesmo tempo de retenção do padrão da microcistina-LR. 


\section{Lista de Tabelas}

Tabela 1 - Variáveis testadas....................................................... 55

Tabela 2 - Proporção das fases móveis conforme o tempo de corrida, gradiente testado

Tabela 3 - Proporção das fases conforme o tempo de corrida. Utilizada na validação do método

Tabela 4 - Condições cromatográficas utilizadas na validação do método

Tabela 5 - Solventes e proporções testadas para condicionamento, lavagem e eluição do cartucho de C18.............................. 71

Tabela 6 - Porcentagem de recuperação de microcistina-LR após a aplicação da extração em fase sólida. Descrição dos testes vide Tabela 2

Tabela 7 - Dados da determinação do limite inferior de quantificação

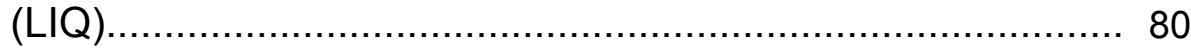

Tabela 8 - $\quad$ Exatidão/ Precisão Intercorridas...................................... 81

Tabela 9 - $\quad$ Dados da Exatidão/ Precisão Intercorridas.......................... 82

Tabela 10 - Representação do gradiente utilizado na Robustez Orgânico Acima........................................................... 84

Tabela 11 - Representação do gradiente utilizado na Robustez Orgânico Abaixo........................................................... 85

Tabela 12 - Resultados da avaliação da robustez do método validado.... 87

Tabela 13 - Estabilidade das soluções padrão, 24 e 48 horas em temperatura ambiente................................................ 88

Tabela 14 - Resultados dos testes de recuperação.............................. 89

Tabela 15 - Dados da curva analítica obtida com a resposta das áreas dos picos cromatográficos referentes ao padrão de microcistina-LR.......................................................... 91

Tabela 16 - Dados da curva analítica obtida com a resposta das alturas dos picos cromatográficos referentes ao padrão da microcistina-LR ......................................................... 93

Tabela 17 - Resultados das análises das amostras de florações de cianobactérias 


\section{SUMÁRIO}

RESUMO

ABSTRACT

Lista de Figuras

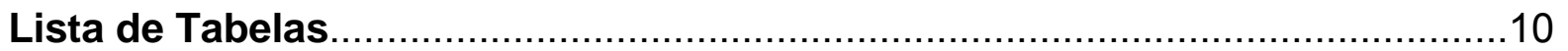

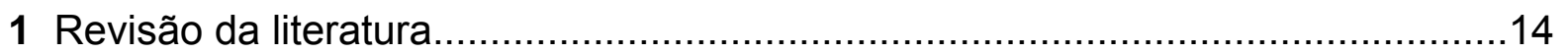

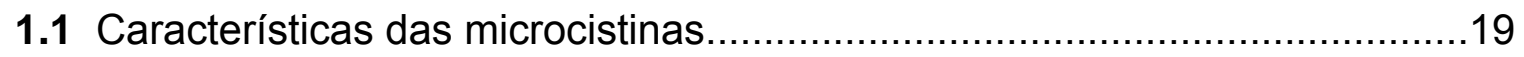

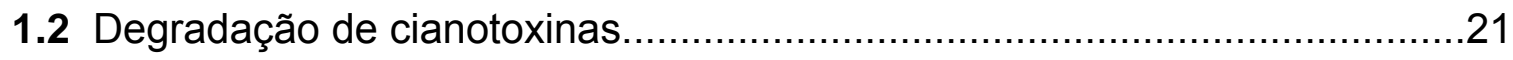

1.3 Contribuição da aqüicultura na proliferação de algas...................................23

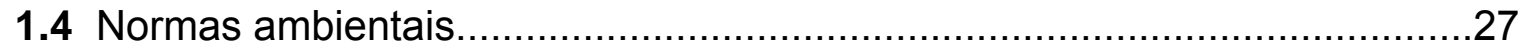

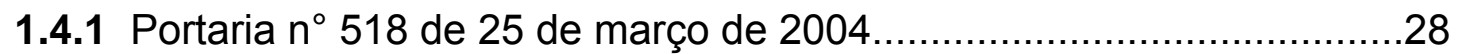

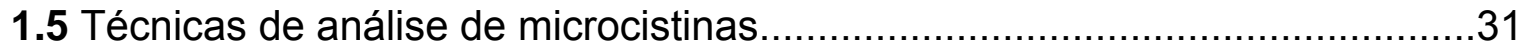

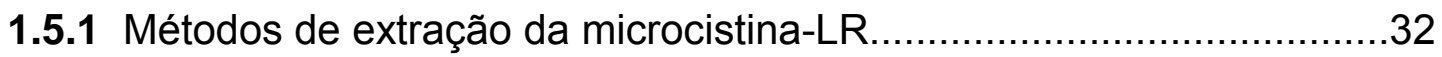

1.5.2 Pré-tratamento da amostra: "clean-up".............................................34

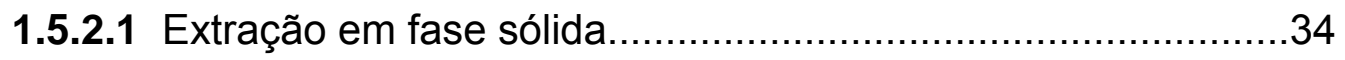

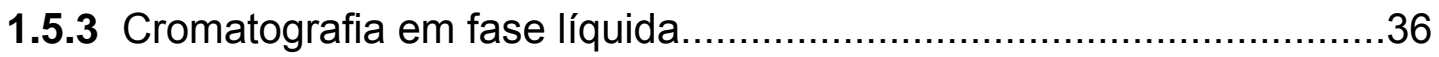

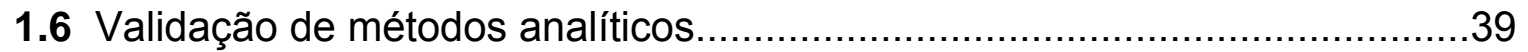

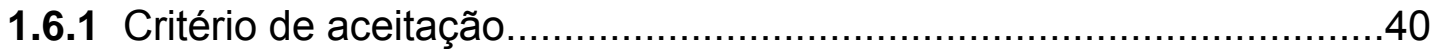

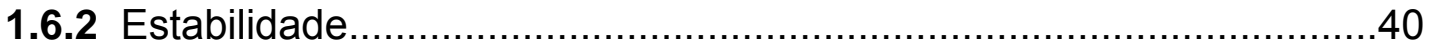

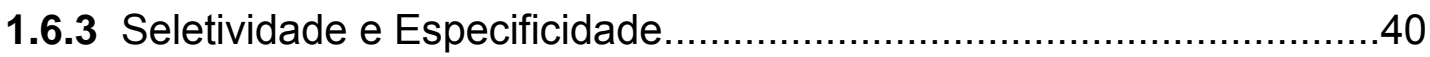

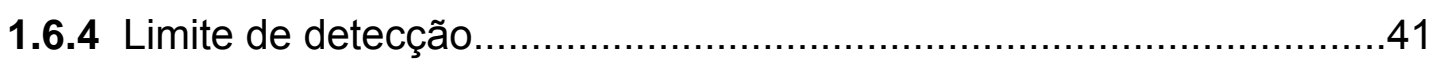

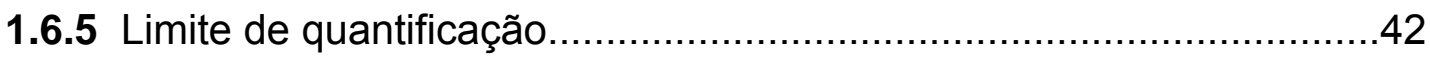

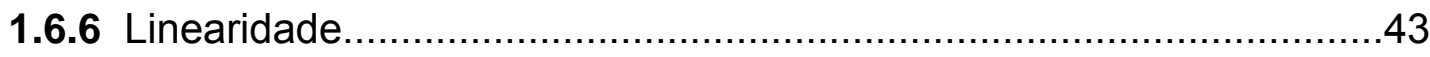

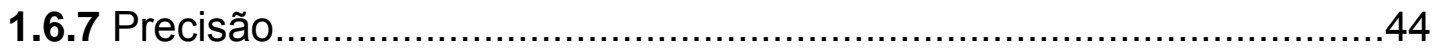

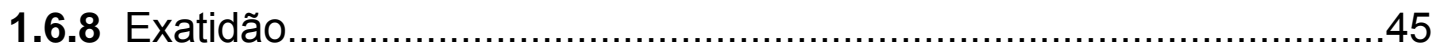

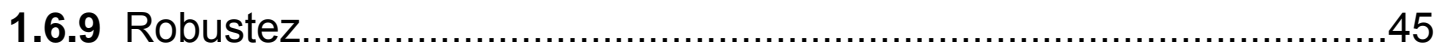

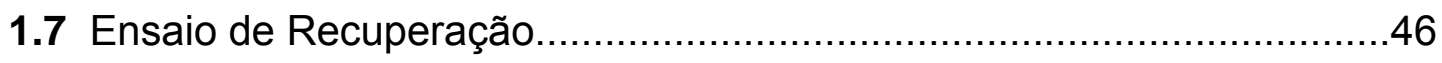

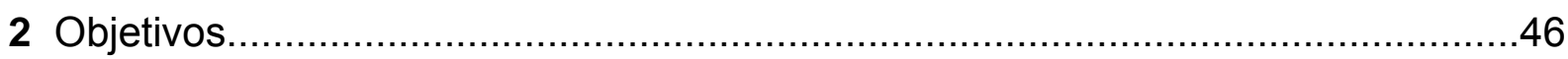

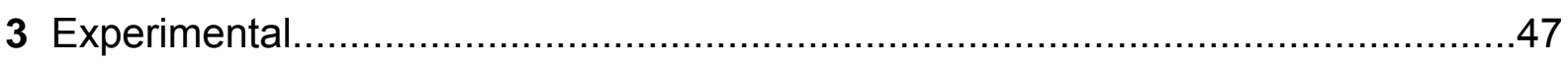

3.1 Critério para a escolha dos estabelecimentos amostrados ..........................47

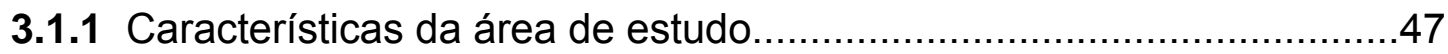

3.1.2 Coleta das amostras de florações de cianobactérias.......................... 50

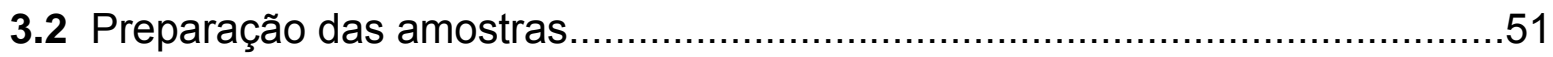

3.3 Procedimento da extração em fase sólida (SPE) ........................................52 
3.3.1 Materiais .52

3.3.1.1 Dados dos padrões de microcistina-LR .............................52

3.3.1.2 Dados do cartucho de SPE..........................................52

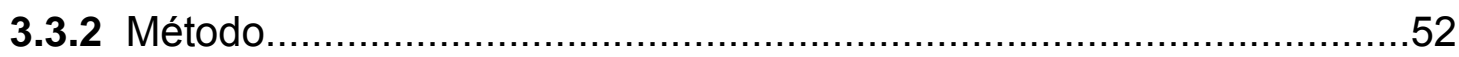

3.4 Determinação cromatográfica da microcistina-LR .................................53

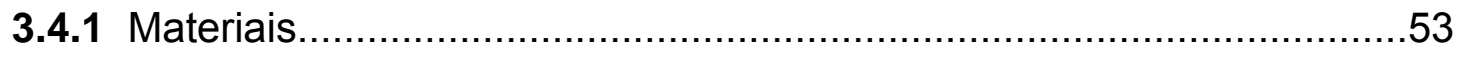

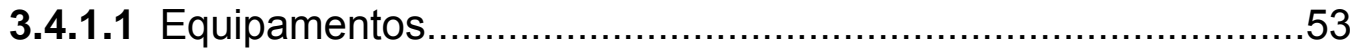

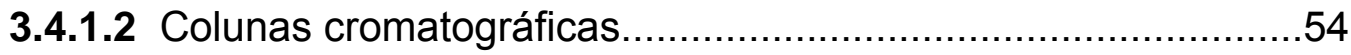

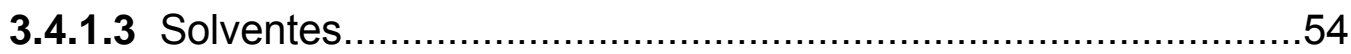

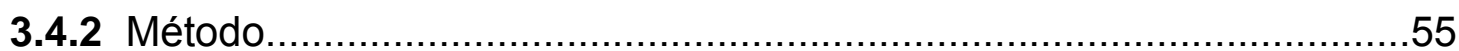

3.5 Parâmetros utilizados na validação do método para a determinação da microcistina-LR em amostras de florações de cianobactérias.......................55

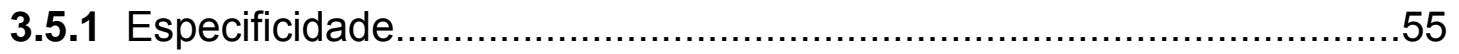

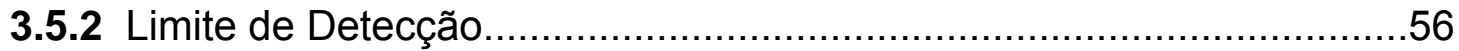

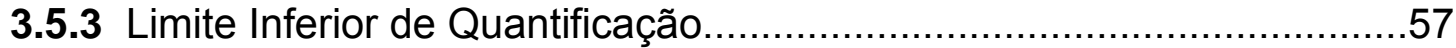

3.5.4 Precisão e Exatidão Intra e Intercorridas..........................................58

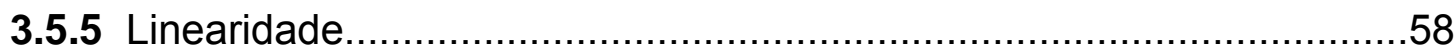

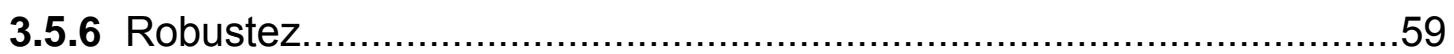

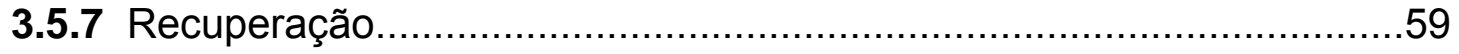

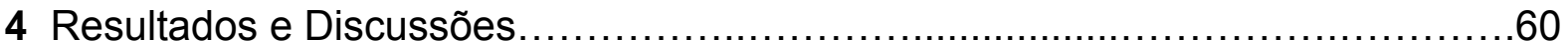

4.1 Espectro de UV do padrão da microcistina-LR ........................................60

4.2 Condições cromatográficas estudadas.....................................................61

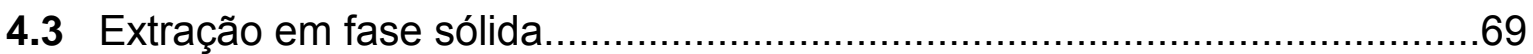

4.4 Validação do método analítico de determinação e quantificação da

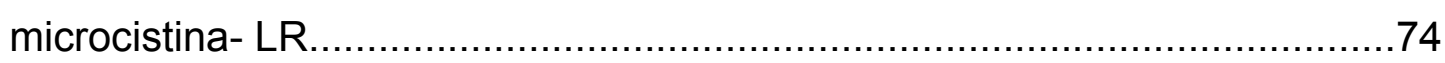

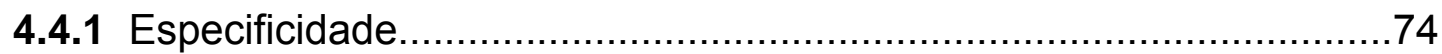

4.4.2 Limite de Detecção....................................................................76

4.4.3 Limite Inferior de Quantificação (LIQ) .........................................78

4.4.4 Exatidão e Precisão Intracorrida........................................................80

4.4.5 Exatidão e Precisão Intercorrida.................................................... 81

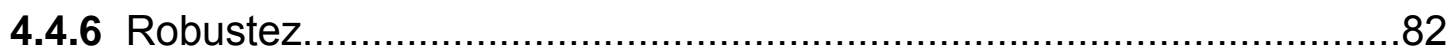

4.4.6.1 Fluxo da fase móvel..................................................... 83

4.4.6.2 Proporção da fase móvel..................................................84

4.4.6.3 Troca de coluna............................................................... 
4.4.6.4 Resultados da Robustez.

4.4.7 Estabilidade da solução padrão de microcistina- LR em metanol

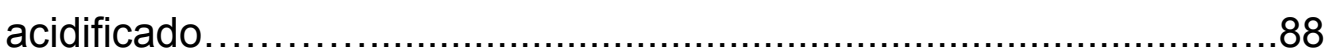

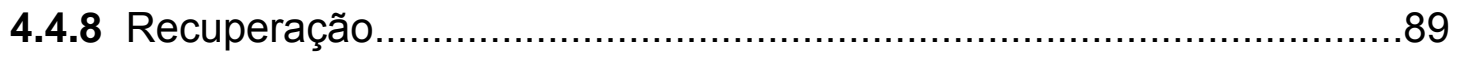

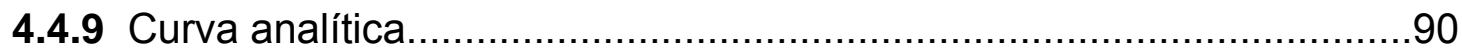

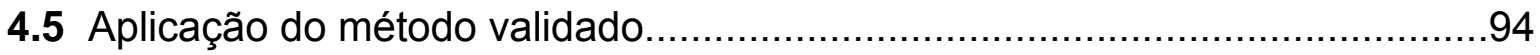

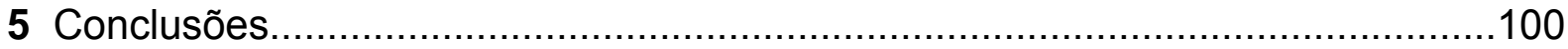

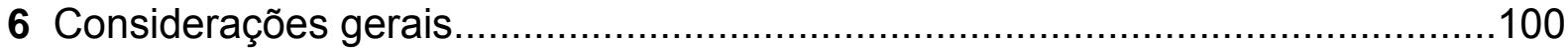

7 Referências Bibliográficas....................................................................... 101 


\section{1 - Revisão da literatura}

Prosseguir com o desenvolvimento industrial e tecnológico e ainda, preservar os diversos ecossistemas e recuperar o equilíbrio ecológico é talvez um dos maiores desafios do homem no século XXI. A contaminação ambiental tem ocorrido de forma desorientada, principalmente em fontes naturais, devido à crescente carga de efluentes lançados na água. O desenvolvimento agrícola ou zootécnico associado a manejos incorretos, por exemplo, tem modificado diversos ecossistemas e impactado, negativamente, em diferentes corpos d’água como lagos, rios, mares, açudes e até mesmo reservatórios urbanos (FIGUEIREDO et al., 2004).

Um dos eventos que ocorrem nos ecossistemas aquáticos mais comumente associados às cargas poluidoras, formadas principalmente por compostos polifosfatados e nitrogenados, são as florações de cianobactérias. Florações são crescimentos populacionais massivos e descontrolados destes microrganismos em ecossistemas aquáticos ocasionados por alterações ambientais, estas florações ou "blooms" se caracterizam por uma densa camada de células com vários centímetros de espessura na superfície da água (RUANGYUTTIKARN et al., 2004).

As florações de cianobactérias podem causar gosto e odor desagradáveis na água, além de alterar o equilíbrio ecológico do ecossistema aquático. O maior problema, entretanto, está no fato de que as cianobactérias podem produzir toxinas, que podem atingir um conjunto de organismos além daqueles presentes nas comunidades aquáticas (MOHAMED, 2006). Acredita-se que, a produção e a liberação dessas cianotoxinas estejam relacionadas com a competição entre os organismos fitoplanctônicos e que possam também atuar inibindo a predação por consumidores primários (larvas de peixes, moluscos, microcrustáceos, dentre 
outros) (BRASIL, 2003). As cianotoxinas podem ser acumuladas na cadeia trófica, ocasionando diferentes sintomas de intoxicação e efeitos crônicos, muitas vezes difíceis de serem diagnosticados (CARMICHAEL, 1992).

As primeiras cianobactérias foram encontradas em fósseis de rochas sedimentares do Noroeste da Austrália com mais de 3,5 bilhões de anos. Estes microrganismos foram os primeiros produtores primários de matéria orgânica a liberarem oxigênio elementar na atmosfera primitiva (CARMICHAEL, 1992). Com o tempo, desenvolveram características que os tornaram capazes de se adaptarem aos ambientes eutróficos e serem dominantes como pigmentos que permitem uma eficiente absorção de luz, armazenamento de nutrientes em seu citoplasma e mecanismos de assimilação de nitrogênio e fósforo do meio aquático. Ambientes de água doce são favoráveis para o crescimento das cianobactérias, pois a maioria das espécies se adapta melhor em águas neutro-alcalinas ( $\mathrm{pH} 6-9)$, temperatura em torno de $25^{\circ} \mathrm{C}$ e alta concentração de nutrientes, principalmente nitrogênio e fósforo (LORENZI, 2004).

As cianobactérias produzem diferentes metabólitos secundários, sendo que alguns deles apresentam ação tóxica sobre diversos organismos. As neurotoxinas e hepatotoxinas, entretanto, podem ser consideradas como os principais agentes tóxicos produzidos pelas cianobactérias, pois causam sérios danos à saúde humana e de outros animais, podendo até mesmo levar à morte (CARMICHAEL, 1992). As hepatotoxinas são as toxinas produzidas por cianobactérias mais comumente relacionadas com casos de envenenamento animal e humano. Hepatotoxinas são moléculas cíclicas com 5 ou 7 peptídeos, de baixa massa molecular, chamados nodularinas ou microcistinas. 
De acordo com Sant'Anna e Azevedo (2000) já foi registrada a ocorrência de pelo menos 20 espécies de cianobactérias potencialmente tóxicas, incluídas em 14 gêneros, em diferentes ambientes aquáticos brasileiros. De acordo com esses autores, a espécie Microcystis aeruginosa se apresenta em maior quantidade no Brasil e Anabaena é o gênero com o maior número de espécies potencialmente tóxicas (A. circinalis, A. flos-aquae, A. planctonica, A. solitaria e A. spiroides).

Se uma pessoa ingerir água ou peixe contaminado, pode apresentar cefaléia, febre, dor abdominal, náusea e vômitos. A morte geralmente é causada por lesão hepática ou do sistema nervoso, dependendo do tipo de toxina predominante na água ou no peixe. Em peixes, os efeitos agudos de microcistinas incluem danos hepáticos, além de distúrbios na regulação iônica, mudanças comportamentais e mortalidade, tendo como mecanismo toxicocinético a penetração nos tecidos através do trato gastrintestinal e, em menor escala, através das brânquias e pele. Além disso, a ação sinergística de diferentes toxinas e de outras substâncias presentes na célula da cianobactéria pode aumentar consideravelmente sua toxicidade (TENCALLA et al., 1994; BURY et al., 1996)

Animais com hepatotoxicose são levados à morte após alteração citoesquelética das células do fígado, causando hemorragia intra-hepática letal ou insuficiência hepática. A hepatotoxina mais comum é a microcistina com $\mathrm{DL}_{50}-24 \mathrm{~h}$ entre 43 e $250 \mathrm{mg} \mathrm{kg}^{-1}$ de peso corpóreo (CHORUS e BARTRAM, 1999). Em nível molecular, as microcistinas agem como inibidores das proteínas fosfatase 1 (PP1) e 2A (PP2A) (MACKINTOSH et al., 1990, LANKOFF et al. 2004). E a exposição a doses subletais pode contribuir, em longo prazo, para o desenvolvimento de tumores cancerígenos (FUJIKI, 1992; MACKINTOSH, 1994). Na China, estudos mostraram correlação entre a baixa concentração de microcistinas presentes na água 
consumida pela população e o aparecimento de câncer de fígado (CHEN et al., 1996).

Estudos in vitro demonstraram os efeitos citotóxicos da microcistina-LR em células humanas como eritrócitos, linfócitos, células endoteliais, epiteliais e fibroblastos (MCDERMOTT et al., 1998; LANKOFF et al., 2004; SICINSKA et al., 2006), bem como em ratos (MCDERMOTT et al., 1998) e em linfócitos de galinha e peixe, especificamente de carpas (LANKOFF et al., 2004; ZHANG et al., 2006). Estudos in vivo relataram também efeitos nefrotóxicos em ratos (MILUTINOVIC et al., 2003), em carpas (RABERGH et al., 1991; FISCHER et al., 2000) e em trutas (KOTAK et al., 1996) e ainda, efeitos citotóxicos gastrintestinais em camundongos (BOTHA et al., 2004, NOBRE et al., 2004).

Além da toxicidade aos seres humanos e animais, estudos mostraram que a microcistina presente na água utilizada para irrigação de cultura de feijão comprometeu a fotossíntese da planta. A microcistina pode interferir na fotossíntese, através de alguns sítios de ação entre estes e às enzimas que catalisam a desfosforilação de proteínas. Células de Microcystis aeruginosa também ficaram retidas em folhas de alface após essas serem irrigadas com água contendo cianobactérias, expondo os seres humanos às cianotoxinas por meio da ingestão desses alimentos contaminados (ALMEIDA, 2002).

Vários problemas de saúde humana foram reportados mundialmente, após o contato com águas contendo floração de cianobactérias, em atividades recreacionais ou pelo consumo de águas de reservatórios contaminados (ELDER et al., 1993; CODD et al., 1989). No Brasil, os estudos que vem sendo realizados no Laboratório de Ecofisiologia e Toxicologia de Cianobactérias da Universidade Federal do Rio de Janeiro (Lect -IBCCF- UFRJ), têm confirmado a ocorrência de cepas tóxicas de 
cianobactérias em corpos d'água (reservatórios de abastecimento público, lagos artificiais, lagoas salobras e rios) situados nos estados de São Paulo, Rio de Janeiro, Minas Gerais, Pará, Paraná, Bahia, Pernambuco e do Distrito Federal. Entretanto, é certo que a ocorrência de cepas tóxicas de cianobactérias não se dá exclusivamente nesses estados. Esses registros refletem que os estudos sobre esse tema estão mais concentrados na região centro-sul do Brasil. Aproximadamente $82 \%$ das cepas isoladas pelo Lect-UFRJ se mostram tóxicas quando testadas em bioensaios de toxicidade ou por análises químicas, sendo $9,7 \%$ neurotóxicas enquanto que as demais são hepatotóxicas.

Outras ocorrências de florações tóxicas também foram comprovadas por meio de bioensaios, em reservatórios de água do Rio de Janeiro por (AGUIAR et al, 1993; BOBEDA et al, 1993; AZEVEDO et al., 1994) e em São Paulo (ZAGATTO et al, 1992; ZAGATTO, 1995).

Em abril de 1996, foi encontrada a microcistina-LR na água do Açude Tabocas, em Caruaru, PE, o qual fornecia água ao reservatório do Instituto de Doenças Renais (IDR) desta cidade. Encontrou-se uma alta concentração de microcistina-LR no filtro de carvão ativado que purificava a água usada pelo IDR (AZEVEDO, 1996, YUAN, et al. 2004). Dos 131 pacientes internados na clínica, 116 apresentaram sintomas de intoxicação. Destes, 100 desenvolveram problemas hepáticos e 76 faleceram. Dos 76 pacientes que vieram à óbito, foram analisadas 52 amostras de fígado e os resultados deram todos positivos para a presença de microcistina-LR (JOCHIMSEN et al., 1998; CARMICHAEL et al., 2001). O filtro de carvão ativado utilizado na clínica foi analisado por cromatografia líquida e apresentou pico cromatográfico característico da microcistina-LR. O diagnóstico etiológico definitivo 
foi dado por Sandra Azevedo, Coordenadora do Núcleo de Pesquisas de Produtos Naturais - CCS - UFRJ.

Em 1998, na Bahia, houve uma epidemia de gastroenterite e após a realização de muitos testes microbiológicos e bioquímicos, a intoxicação também foi atribuída à toxina microcistina-LR (DEBERDT, 2002).

Testes de toxicidade em camundongos confirmaram também a presença de microcistina-LR em grandes quantidades na Lagoa dos Patos, Rio Grande do Sul, onde a água contaminada era utilizada na agricultura, pesca e abastecimento público (ALMEIDA, 2002).

\section{1 - Características das microcistinas}

As microcistinas são peptídeos cíclicos formados por sete aminoácidos, sendo que cinco estão sempre presentes na molécula, e outros dois são variáveis (MSAGAT et al., 2006). Estes dois L-aminoácidos que ocupam a posição X e Z (Figura 1), determinam a toxicidade das diferentes variantes de microcistina, e também de acordo com o trabalho de Carmichael (1992), as microcistinas são nomeadas segundo o tipo destes aminoácidos, e conforme às diferenças no grau de metilação em $\mathrm{R}^{1}$ e $\mathrm{R}^{2}$, apresentado na Figura 1. 


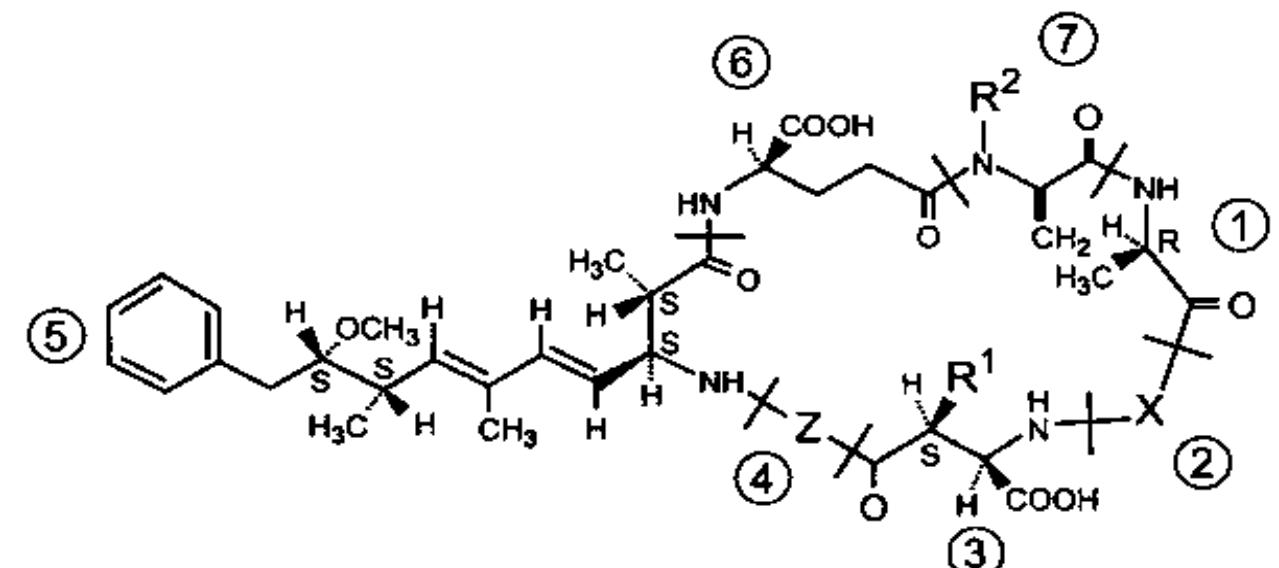

Figura 1: Estrutura cíclica geral das microcistinas onde $X$ e $Z$ representam os dois L-aminoácidos variáveis e $R^{1}$ e $R^{2}$ são os locais de possíveis metilações.

A microcistina-LR apresenta a leucina-arginina como aminoácidos na posição $X$ e $Z$, a microcistina-RR, a arginina-arginina, a microcistina- $Y A$, a tirosina-alanina. (FALCONER et al., 2005).

Já foram identificadas até o presente, cerca de 65 tipos ou variantes de microcistinas em todo mundo. A variante microcistina-LR, apresentada na Figura 2, é uma das formas mais tóxicas já isoladas.

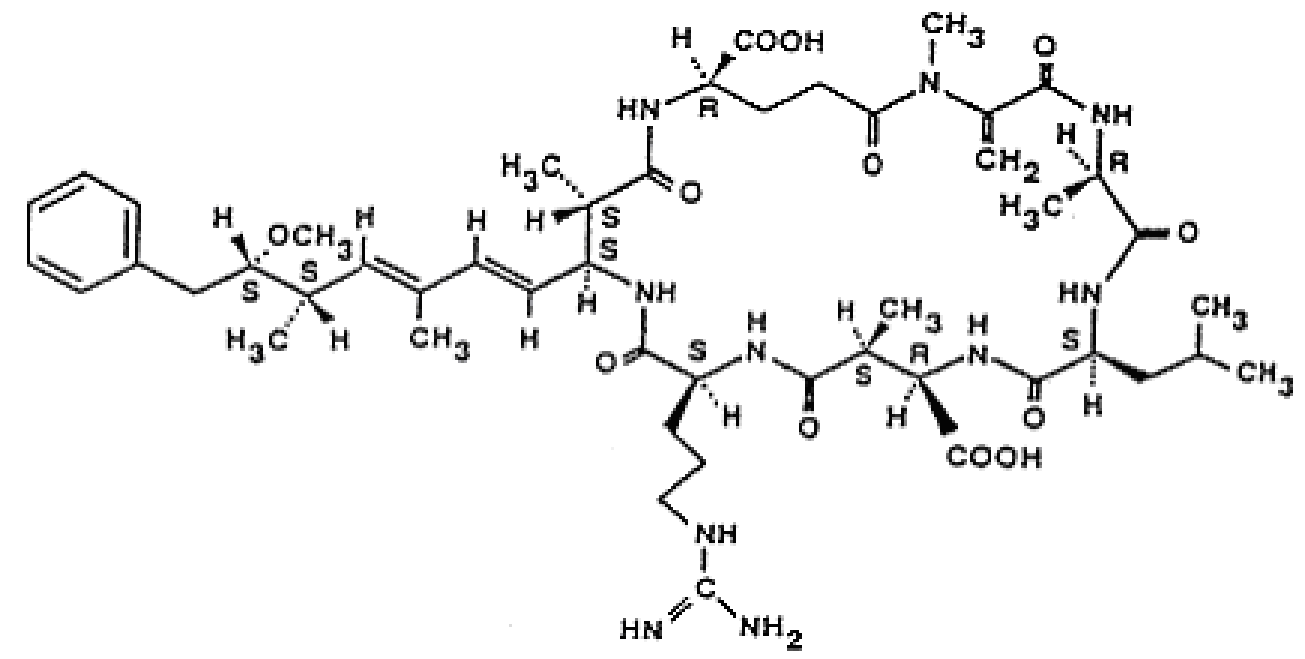

Figura 2: Estrutura da microcistina-LR (RIVASSEAU et al., 1997).

A massa molecular da microcistina é cerca de 1000 daltons e tem a estrutura geral cíclica (-D-Alanina ${ }^{1}-X^{2}-D-M e A s p^{3}-Z^{4}-A_{d d a}^{5}-D-g^{2}$ lutamato $\left.{ }^{6}-M_{d h a}{ }^{7}\right)$, onde D- 
MeAsp é o D-eritro- $\beta$-metil ácido aspártico e Mdha é a N-metildehidroalanina, responsável pela ligação covalente da toxina com a proteína fosfatase (ZHANG et al., 2003).

O aminoácido Adda (3amino-9-metoxi-2,6,8-trimetil-10-fenil-4,6-ácido decadienóico), é a estrutura comum a todos os peptídeos cíclicos de cianobactérias. Modificações na cadeia do Adda, resultam em uma notável diminuição da toxicidade da microcistina-LR, por exemplo, e o Adda livre não apresenta toxicidade (ZHANG et al., 2003).

\section{2 - Degradação de cianotoxinas}

A quantidade de toxina em uma determinada floração varia em função de vários fatores ambientais, como luz, temperatura, quantidade de nitrogênio e fósforo e em função da fisiologia e composição das algas responsáveis pelas florações.

As cianotoxinas que estão contidas no interior das células das cianofíceas podem ser liberadas para o meio líquido após o estresse celular, ou com o uso de algicidas, fornecendo gosto e odor desagradáveis à água. Essas toxinas liberadas para o meio líquido podem persistir nesse ambiente por semanas a meses, dependendo da temperatura, iluminação, $\mathrm{pH}$ e atividade dos microrganismos presentes no meio.

As microcistinas, devido à estrutura peptídica cíclica, são estáveis à hidrólise química e oxidação. Elas são muito resistentes às altas temperaturas e mantêm a toxicidade mesmo após a fervura da água (FERREIRA, 2004).

Em temperaturas elevadas, aproximadamente $40^{\circ} \mathrm{C}$, observa-se a hidrólise lenta das microcistinas. Dez semanas é o tempo em que ocorre a degradação de $90 \%$ das cianotoxinas em $\mathrm{pH} 1$, e em $\mathrm{pH} 9$, esse tempo é de 12 semanas. $\mathrm{Na}$ 
ausência de luz, sob condições naturais, podem persistir na natureza por meses ou anos. Sob luminosidade, apresenta lenta degradação fotoquímica, mas que pode ser acelerada por pigmentos fotossintéticos hidrossolúveis (BRASIL, 2001).

Em Armidale, Austrália, o reservatório de água para abastecimento público foi monitorado devido à ocorrência de florações tóxicas de Microcystis por vários anos. Quando uma densa floração ocorreu, a água foi tratada com sulfato de cobre durante três semanas, para matar a floração, porém um estudo epidemiológico na população local indicou que ocorreram danos no fígado dos mesmos, após o extermínio da floração (DEBERDT, 2002). A remoção das células de cianofíceas intactas resulta em uma significante redução de gosto, odor e metabólitos tóxicos na água. Uma alternativa seria utilizar o algicida hidróxido de cálcio, que não destrói as células, deixando-as intactas, coagulando e precipitando o fitoplâncton. O hidróxido de cálcio não apresenta elevada toxicidade, tem baixo custo e também reduz a eutrofização pela precipitação do fósforo (ALMEIDA, 2002).

Uma vez que a remoção das microcistinas pode não ser eficiente com os tratamentos convencionais das estações de tratamento de água, há estudos como o de Lawton et al. (1998), que compara a eficiência de filtros domésticos de água para a remoção de microscistinas e células de cianobactérias em água de abastecimento. Após a seqüência de três filtrações, a remoção da microcistina-LR foi de $77 \%$ e a remoção das microcistinas-LY, -LW e -LF ficou por volta de $87 \%$. Os autores concluíram que a remoção da microcistina-LR foi menor por ser a mais polar das microcistinas, ou seja, a mais hidrofílica. A maior afinidade da microcistina-LR com a água torna mais difícil sua remoção.

Os resultados obtidos por Hart et al. (1998) confirmam a efetividade do carvão ativado granular na remoção da microcistina-LR e também da anatoxina-a. A partir 
dos dados experimentais e da utilização de modelos matemáticos, os autores sugerem que o carvão ativado granular biologicamente ativo é capaz de remover completamente as toxinas em menores tempos de contato. Se o mecanismo de remoção da microcistina por carvão ativado for unicamente à adsorção, tempos de contato superiores a 30 minutos serão necessários para a remoção dessas toxinas nas concentrações associadas às florações de cianobactérias.

\section{3 - Contribuição da aqüicultura na proliferação de algas}

São vários os exemplos da expansão e da integração da aqüicultura com outras atividades agropecuárias, turísticas e industriais, como por exemplo, a piscicultura comercial intensiva em grande escala, as pisciculturas integradas às pequenas propriedades rurais, a criação de peixes em tanques-rede nos grandes reservatórios das hidroelétricas das bacias hidrográficas, e os sistemas de pesquepagues. Atualmente existem muitos pesque-pagues espalhados pelo Estado de São Paulo, e na região do Alto Mogi, local deste estudo, a quantidade desses estabelecimentos é ainda maior.

Embora atualmente seja reconhecido o mérito que a aqüicultura possui em relação à produção de alimentos, manutenção de estoques pesqueiros com proteção e conservação de espécies, integração com a agricultura, entre outros, também têm sido reconhecidos os impactos aos sistemas naturais que recebem seus efluentes (Rosenthal, 1994). A eutrofização dos recursos hídricos é indicada como um dos mais significativos impactos causados pela aqüicultura.

O aumento da concentração de substâncias orgânicas no sistema aquático, resulta em alterações físicas e químicas da água, como a redução elevada da concentração de oxigênio dissolvido e uma conseqüente mortandade de peixes. 
Além disso, o aumento de nutrientes presentes na água de pisciculturas, quando em conjunto com outros fatores como temperaturas elevadas e luminosidade, favorecem a ocorrência e o crescimento de florações de algas, assim como de cianobactérias tóxicas (BELL \& CODD, 1994).

Tanto as lagoas de estabilização usadas no tratamento de esgotos e efluentes industriais como os viveiros de aqüicultura em água doce e salobra podem conter densidades elevadas de cianobactérias. Quando a água que passou por estas lagoas e viveiros é descartada no meio ambiente, o efluente do empreendimento pode transportar uma quantidade suficiente de cianobactérias para fazer o corpo receptor ultrapassar os limites da legislação. A Figura 3 apresenta um exemplo de como pode ocorrer essa contaminação.

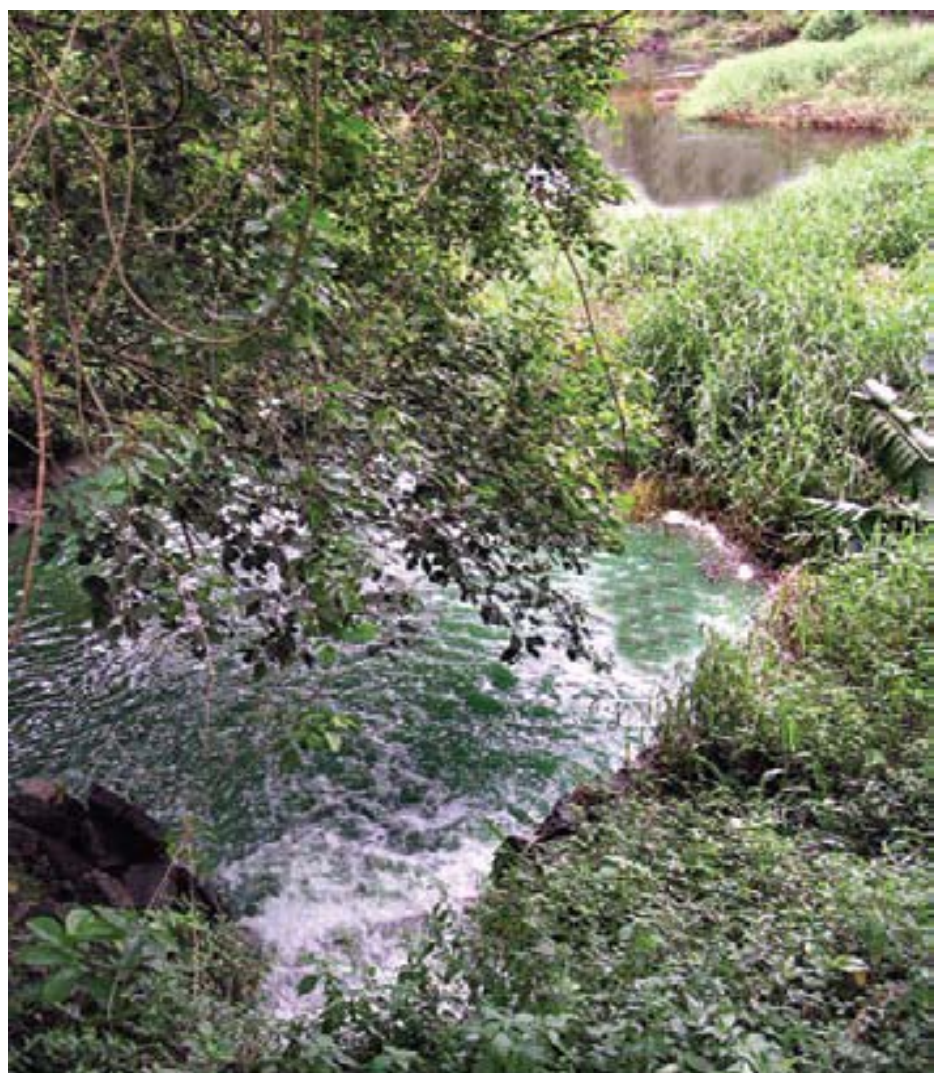

Figura 3: Lançamento de efluente contendo cianobactérias (água verde, em primeiro plano) num curso d'água originalmente sem cianobactéria (ao fundo, água de montante escura pelo húmus). As cianobactérias devem ser removidas antes deste descarte. 
Em estudos de monitoramento em um pesque-pague situado na região de Descalvado-SP, foi observada a presença de florações tóxicas de cianobactérias, que provocaram a mortandade de um grande número de peixes. Foram feitas análises da água e dos peixes expostos às florações, sendo constatada a presença de microcistinas, das espécies Microcystis aeruginosa e Anabaena spiroides (ELER, 2000).

Pesquisas têm demonstrado o perigo da bioacumulação de microcistina em invertebrados e vertebrados aquáticos, incluindo os peixes, que participam da cadeia alimentar humana (MAGALHÃES et al., 2001; MAGALHÃES et al., 2003; FIGUEIREDO et al., 2004; PINHO et al., 2005; et al., 2007). Mohamed et al. (2003) relataram o acúmulo de microcistina no intestino, no fígado e no rim de tilápias (O. niloticus). Em ensaio experimental, Soares et al. (2004) também relataram sobre a bioacumulação da microcistina-LR no músculo e em maior concentração no fígado de peixes (T. rendalli). Li et al. (2004) observaram acúmulo de microcistina-LR no fígado (aproximadamente 108,3 $\mathrm{ng} \mathrm{g}^{-1}$ de peixe) e no músculo (aproximadamente $12,3 \mathrm{ng} \mathrm{g}^{-1}$ de peixe) de carpas (Cyprinus carpio). Segundo estes autores, a microcistina pode ser parcialmente excretada pelas fezes do animal após a biotransformação, sendo o restante da toxina acumulado no fígado, músculo e outros tecidos. Malbrouck et al. (2003) inocularam microcistina-LR (125 $\mathrm{gg} \mathrm{kg}^{-1} \mathrm{de}$ peso corporal) intraperitonealmente em "goldfish" (Carassius auratus) jovens. Estes autores também observaram acúmulo de toxina no fígado. Contudo, após 21 dias do experimento, os autores relataram ter havido diminuição da concentração da toxina no fígado dos animais estudados.

Os moluscos filtradores bivalves, como os mexilhões e mariscos, também podem apresentar considerável acúmulo de cianotoxinas, pois, além de se 
alimentarem exclusivamente de fitoplâncton, são muito resistentes às toxinas. Existe uma vasta literatura sobre a bioacumulação de cianotoxinas (microcistina, nodularina e cilindrospermopsina) pelos mexilhões de água doce e marinhos, bem como os aspectos de depuração e tecidos afetados, tópicos discutidos por Meriluoto et al., (2007).

Os efeitos causados por microcistinas não se limitam apenas aos organismos que foram expostos a esses compostos, uma vez que alguns estudos indicam que essas toxinas podem acumular na cadeia trófica, funcionando muitas vezes, como um vetor de transferência para outros organismos e para os seres humanos (MAGALHÃES et al., 2000).

Um estudo desenvolvido em 39 pesque-pagues que lançam seus efluentes na bacia do rio Mogi Guaçu, demonstrou que o impacto dessa atividade deve ser estimado por meio do monitoramento das variáveis físicas e químicas da qualidade da água ao longo da extensão da bacia, assim como da qualidade da água dos efluentes lançados no rio pelas propriedades pesqueiras. Ainda dentro deste contexto, cerca de $80 \%$ das propriedades estudadas apresentavam florações de algas, inclusive de cianobactérias produtoras de toxinas. Os autores constataram a presença de espécies como Microcystis aeruginosa e Anabaena spiroides (ELER, 2000).

Magalhães et al., (2000), encontraram microcistinas em uma concentração próxima e também acima do limite recomendável pela Organização Mundial da Saúde $\left(0,04 \mu \mathrm{gg}^{-1}\right.$ de peso corpóreo/dia) após 25 dias do início de uma floração de cianobactérias, o que confirma o acúmulo e a permanência de hepatotoxinas nos músculos dos peixes, e conseqüentemente o risco potencial do consumo deste pescado (TENCALLA et al., 1994; BURY et al., 1996). 
Ressalta-se dessa forma, a necessidade urgente de monitorar os sistemas de produção de peixes e de pesca esportiva, que podem funcionar como uma nova rota de intoxicação dos seres humanos e outros animais por toxinas de ação direta e acumulativa, como são as microcistinas (RIBEIRO et al., 2000).

\section{4 - Normas ambientais}

Muitos casos de intoxicação por cianobactérias já foram registrados no mundo todo, e em países desenvolvidos esse controle já existe há alguns anos. Os países, Austrália e Canadá, por exemplo, já estabeleceram um nível máximo para microcistina em água de abastecimento público. Na Austrália, uma proposta para uma concentração limite de microcistinas que não apresente efeito adverso à saúde pública foi publicada por Falconer et al., (1994). A proposta que resultou desse trabalho, incluindo a incorporação de um fator de segurança contra a promoção de tumores é de 1,0 $\mu \mathrm{g}$ de microcistina ou nodularina por litro de água. Um número

similar foi apresentado em 1994 no Canadá, $0,5 \mu \mathrm{g} \mathrm{L}^{-1}$ para a microcistina-LR (KUIPER-GOODMAN et al., 1994).

Para se estabelecer os padrões de segurança da água são necessárias demonstrações dos efeitos de toxicidade, dose-dependente, e determinação dos níveis máximos que não causam efeitos adversos ou nível máximo aceitável.

A Organização Mundial de Saúde (O.M.S), em 1997, após várias opiniões com pesquisadores de diferentes países, decidiu editar um "Guideline" específico para toxinas de cianobactérias em águas de abastecimento público, em que foi estabelecido o limite de $1,0 \mu \mathrm{g} \mathrm{L}^{-1}$, como concentração máxima aceitável para consumo oral humano diário (GUPTA, 1998: WHO, 1998). 
A morte de pacientes de uma clínica de hemodiálise, em Caruaru PE, alertou os órgãos de saúde do país para o perigo representado pela presença de cianobactérias na água. Este incidente levou a Fundação Nacional de Saúde, em colaboração com a Organização Panamericana da Saúde, à revisão da portaria 36/MS/90, que definia as normas e os padrões de potabilidade da água para o consumo humano no Brasil. Por meio da homologação da Portaria $n^{\circ}$ 1469/00/MS de 29/12/2000, a Agência Nacional de Vigilância Sanitária passou a exigir dos órgãos competentes e responsáveis pelo tratamento e fornecimento de água, o monitoramento da ocorrência de cianobactérias e algumas cianotoxinas, tanto na água bruta do manancial utilizado para a captação de água, como na água tratada para consumo humano (BRASIL, 2001).

\subsection{1 - Portaria n 518 de 25 de março de 2004}

A Portaria $\mathrm{n}^{\circ} 518$ de 25 de março de 2004, apresenta uma norma que dispõe sobre procedimentos e responsabilidades inerentes ao controle e à vigilância da qualidade da água para consumo humano, estabelece seu padrão de potabilidade e dá outras providências, faz diversas referências e recomendações ao que se refere as microcistinas, produzidas por cianobactérias, objeto de estudo desta pesquisa. As citações que correspondem às microcistinas podem ser conferidas nos seguintes artigos: $2^{\circ}, 14^{\circ}\left(\S 1^{\circ}\right), 17^{\circ}\left(\S 1^{\circ}\right), 18^{\circ}\left(\S 5^{\circ}\right)$ e $19^{\circ}\left(\S 1^{\circ}\right.$ e $\left.\S 2^{\circ}\right)$.

O segundo artigo estabeleceu o prazo máximo de 12 meses, contados a partir da publicação da portaria anteriormente citada, para que as instituições ou órgãos aos quais esta norma se aplica, promovessem as adequações necessárias a seu cumprimento, no que se refere ao tratamento por filtração de água para consumo 
humano, suprida por manancial superficial e distribuída por meio de canalização e da obrigação do monitoramento de cianobactérias e cianotoxinas.

No décimo quarto artigo, está incluída uma Tabela (Padrão de potabilidade para substâncias químicas que representam risco à saúde), na qual estão relacionadas substâncias químicas que representam risco para a saúde e os seus respectivos VMP (Valor Máximo Permitido), o valor máximo permitido relacionado à microcistina é de 1,0 $\mu \mathrm{g} \mathrm{L}^{-1}$, Também no décimo quarto artigo, recomenda-se que as análises para cianotoxinas incluam a determinação de cilindrospermopsina e saxitoxinas (STX), observando, respectivamente, os valores limites de $15,0 \mu \mathrm{g} \mathrm{L}^{-1} \mathrm{e}$ $3,0 \mu \mathrm{g} \mathrm{L}^{-1}$ de equivalentes STX/L.

O décimo sétimo artigo faz referência às metodologias analíticas para a determinação dos parâmetros físicos, químicos, microbiológicos e de radioatividade, que devem atender às especificações das normas nacionais que disciplinem a matéria, da edição mais recente da publicação Standard Methods for the Examination of Water and Wastewater, de autoria das instituições American Public Health Association (APHA), American Water Works Association (AWWA) e Water Environment Federation (WEF), ou das normas publicadas pela ISO (International Standartization Organization). O primeiro parágrafo, ainda do décimo sétimo artigo, especifica que, para análise de cianobactérias e cianotoxinas e comprovação de toxicidade por bioensaios em camundongos, até o estabelecimento de especificações em normas nacionais ou internacionais que disciplinem a matéria, devem ser adotadas as metodologias propostas pela Organização Mundial da Saúde (OMS) em sua publicação "Toxic cyanobacteria in water: a guide to their public health consequences, monitoring and management". 
No quinto capítulo da Portaria, que regulamenta os planos de amostragens, o décimo oitavo artigo estabelece que os responsáveis pelo controle da qualidade da água de sistema ou solução alternativa de abastecimento de água devem elaborar e aprovar, junto às autoridades de saúde pública, o plano de amostragem de cada sistema, respeitando os planos mínimos de amostragem expressos nas Tabelas de 6 - 9, (que estão descritas na Portaria). Na Tabela 7 (da Portaria), que estabelece a freqüência mínima de amostragem para o controle da qualidade da água de sistema de abastecimento, para fins de análises físicas, químicas e de radioatividade, em função do ponto de amostragem, da população abastecida e do tipo do manancial, está estabelecido em relação à microcistina, que sejam feitas amostragens semanalmente (conforme quinto parágrafo do décimo oitavo artigo) nos mananciais superficiais. O quinto parágrafo estabelece que sempre que o número de cianobactérias presentes na água do manancial, no ponto de captação, exceder 20.000 células $\mathrm{ml}^{-1}$, durante $\mathrm{o}$ monitoramento que trata o primeiro parágrafo do décimo nono artigo, será exigida a análise semanal de cianotoxinas em amostras de água na saída do tratamento e nas entradas (hidrômetros) das clínicas de hemodiálise e indústrias que fabricam produtos injetáveis, sendo que esta análise pode ser dispensada quando não houver comprovação da presença das toxinas na água bruta por meio da realização semanal de bioensaios em camundongos.

O segundo parágrafo do décimo nono artigo, faz menção à microcistina (cianotoxina), no que diz respeito à proibição do uso de algicidas para o controle do crescimento de cianobactérias ou qualquer intervenção no manancial que provoque a lise das células desses microrganismos, quando a densidade das cianobactérias exceder 20.000 células $\mathrm{mL}^{-1}$, sob pena de comprometimento da avaliação de riscos à saúde associado às cianotoxinas (BRASIL, 2004). 
Se forem seguidas todas as instruções dessa Portaria, que foi confeccionada focada nas florações de cianobactérias, poderemos minimizar as conseqüências causadas pelas mesmas nas águas para abastecimento público, para recreação e para a aquicultura.

\section{5 - Técnicas de análise de microcistinas}

Muitos métodos de análise e de extração de cianotoxinas vêm sendo desenvolvidos, cada um com a sua peculiaridade e conseqüente dificuldade analítica. Por isso a busca por novas técnicas tem sido contínua, principalmente por se tratar de um assunto de suma importância para a saúde pública.

Os métodos instrumentais para a determinação de microcistinas iniciaram-se com a CLAE (cromatografia líquida de alta eficiência) e detecção em UV (238 nm) com "photodiode array"- PDA (HARADA et al., 1988; SANO et al., 1992; EDWARDS et al., 1996). Os avanços introduziram a nanotecnologia, com as confirmações adicionais e identificação de microcistinas, baseadas em espectrometria de massas LC/MS/MS (KONDO et al., 1996; HARADA et al., 1996). Destaca-se também o "Matrix Assisted Laser Desorption Ionization Time of Flight" (MALDI-TOF), que embora não seja quantitativo, permite uma avaliação rápida e qualitativa de perfil peptídico produzido, indicando inclusive, a presença das variações de microcistinas (IMANISHI; HARADA, 2004).

Para An \& Carmichael (1994) o ensaio da inibição das fosfatases proteicas na determinação de nodularinas e microcistinas poderá ser complementado com o ensaio imunológico ELISA (Enzyme Linked Immunosorbent Assay) utilizando anticorpos que foram desenvolvidos contra a microcistina-LR (CHU et al., 1989). A 
primeira técnica imunológica ELISA para microcistinas e nodularinas foi desenvolvida por Chu et al. (1989).

Atualmente existem kits comerciais que são muito utilizados em laboratórios de monitoramento de microcistinas e nodularinas na água (EnviroGard® Microcystins Plate Kit e Envirologix). O ensaio ELISA aproveita a especificidade dos anticorpos de coelho contra microcistina-LR, para detectar de forma seletiva moléculas de microcistina-LR, -RR, -YR e nodularinas. A especificidade do anticorpo para estas cianotoxinas deve-se essencialmente aos dois aminoácidos nelas presentes: Adda e arginina (AN \& CARMICHAEL, 1994). Empregando-se padrão de microcistina com concentração conhecida e de uma reação colorimétrica anticorpo/ antígeno, traça-se uma reta padrão para determinar a concentração de microcistinas na amostra.

\subsection{1 - Métodos de extração da microcistina-LR}

$\mathrm{Na}$ literatura encontram-se métodos de extração que variam muito, por exemplo, para promover a extração da microcistina-LR em florações de cianobactérias, pode-se desde deixar a amostra em repouso em um solvente adequado por um determinado tempo, à deixa-la sob agitação contínua, ou sob agitação e subseqüente sonicação, seguida de centrifugação, etc. Tempos de extração também podem variar de poucos minutos à horas, 15 horas, por exemplo, no estudo de Namikoshi et al. (1992). Os autores Coyle e Lawton (1996), fizeram uma comparação entre os tempos de extração de 5, 30 e 60 minutos, e obtiveram uma maior recuperação em 60 minutos, porém 85- 97\% das microcistinas já haviam sido extraídas em 30 minutos. 
A escolha do solvente de extração é muito importante, por isso muitos solventes já foram testados com o intuito de melhorar a extração da microcistina-LR de florações de cianobactérias, solventes como butanol:metanol:água (5:20:75, v/v) (AZEVEDO et al., 1994; NAMIKOSHI et al., 1998), solução aquosa com 5\% de ácido acético, pH 2,7, (HARADA et al., 1988). Em trabalhos como no de Lawton et al. (1995), foi demonstrado que butanol:metanol:água, água, metanol e metanol $70 \%$ são mais eficientes que a solução de ácido acético, porque a hidrofobicidade da microcistina aumenta conforme o pH diminui (MAAGD et al., 1999). Alguns autores também estudaram a extração seqüencial, onde amostras foram inicialmente extraídas em um determinado solvente e re-extraído em um outro, por exemplo, ácido acético $0,05 \mathrm{M}$ : etanol, seguido de ácido acético $5 \%$ ou ácido acético $5 \%$ seguido de metanol, ou ainda água e metanol (HARADA et al., 1991; LAWTON et al., 1995).

Embora a massa de floração liofilizada utilizada na extração possa influenciar na eficiência, não há estudos sobre a avaliação de uma razão ótima. Uma das razões comumente relatada é na faixa de $10 \mathrm{~g}$ de material liofilizado para $200 \mathrm{~mL}$ de solvente, sendo um dos mais baixos $10 \mathrm{~g}$ para $100 \mathrm{~mL}$ (BOTES, et al.,1982) e um dos altos, $10 \mathrm{~g}$ para $1000 \mathrm{~mL}$ (MARTIN et al., 1990).

Visto que o método de extração pode influenciar muito no rendimento da análise, dentre todas as literaturas revisadas, o trabalho mais completo foi o de Barco et al., (2005), que descreve a comparação de vários métodos de extração, equipamentos, solventes, temperatura e quantidade material utilizado na análise. Foram seguidas as condições que apresentaram uma maior recuperação. 


\subsection{2 - Pré-tratamento da amostra: "clean-up”}

Pouca atenção tem sido dada aos processos de preparação e tratamento de amostras nos últimos anos, porém, este passo é muito importante, pois a preparação da amostra decide, na maioria dos casos, o sucesso na determinação do analito de interesse.

Um procedimento de clean-up pode não ser necessário se a amostra estiver livre de impurezas (interferentes), porém, tal procedimento tem sido recomendado para análise de água, por se tratar de uma matriz complexa e poder apresentar muitas substâncias dissolvidas.

Pesquisas em laboratórios americanos demonstraram que aproximadamente $60 \%$ do tempo de uma análise é utilizado para a preparação da amostra, que consiste em isolar o analito de interesse a partir de uma amostra ambiental ou biológica. A porcentagem de erros de uma análise deve-se ao maior tempo de manipulação, sendo que, a preparação gera $30 \%$ do total de erros ocorridos em um processo completo de determinação (MAJORS, 1991).

\subsubsection{1 - Extração em fase sólida}

A extração em fase sólida, SPE (Solid Phase Extraction) é um dos métodos de extração mais utilizados. Neste método, os analitos contidos em uma matriz aquosa são extraídos, juntamente com os compostos interferentes, após ser percolado através de um cartucho contendo o adsorvente. Um solvente orgânico seletivo é geralmente utilizado para remover os interferentes e então outro solvente é usado para eluir os analitos de interesse. Apesar da SPE apresentar vantagens com relação aos métodos clássicos, tais como praticidade e maior sensibilidade, 
este método tem algumas limitações. Uma delas refere-se à etapa de dessorção do analito retido no cartucho de SPE que requer geralmente, o uso de solventes específicos (LANÇAS, 2002).

A porcentagem de extração quando emprega-se a SPE depende dos solventes utilizados antes e após a passagem da amostra pelo cartucho, portanto, isto justifica a preocupação na escolha do solvente.

O mecanismo de separação baseia-se nas interações intermoleculares entre analito e grupos funcionais do adsorvente.

A escolha do adsorvente a ser usado na SPE é de extrema importância, quando o intuito é o de se obter altas recuperações do analito de interesse, esta escolha depende do analito e suas propriedades. É necessário que os grupos funcionais existentes no adsorvente tenham afinidade pelos analitos e vice-versa.

Analitos polares e moderadamente polares são extraídos de soluções por adsorventes polares, (adsorventes de fase normal, onde a fase estacionária é mais polar que a fase móvel), são modificados com grupamentos ciano, diol ou amino grupos. Analitos não polares e moderadamente polares são extraídos de soluções polares por adsorventes não polares. Adsorventes de fase reversa (fase estacionária menos polar que a fase móvel) são modificados com octadecil-, octil-, ciclohexil-, ou grupos fenóis (TEKEL E HATRÍK, 1996).

O tipo mais comum de extração em fase sólida é a de fase sólida reversa. Neste caso a meta é isolar analitos orgânicos não polares de amostras aquosas predominantemente polares. Isto requer $\mathrm{o}$ uso de partículas adsorventes relativamente hidrofóbicas como a sílica com ligação de grupo octadecilsilano $\left(\mathrm{C}_{18}\right)$, partículas orgânicas porosas com ligação poliestireno, ou vários tipos de carbono 
ativado ou ainda materiais de carbono grafitado (FRITZE MACKA, 2000). A Figura 4 apresenta um cartucho típico empregado em extração em fase sólida.

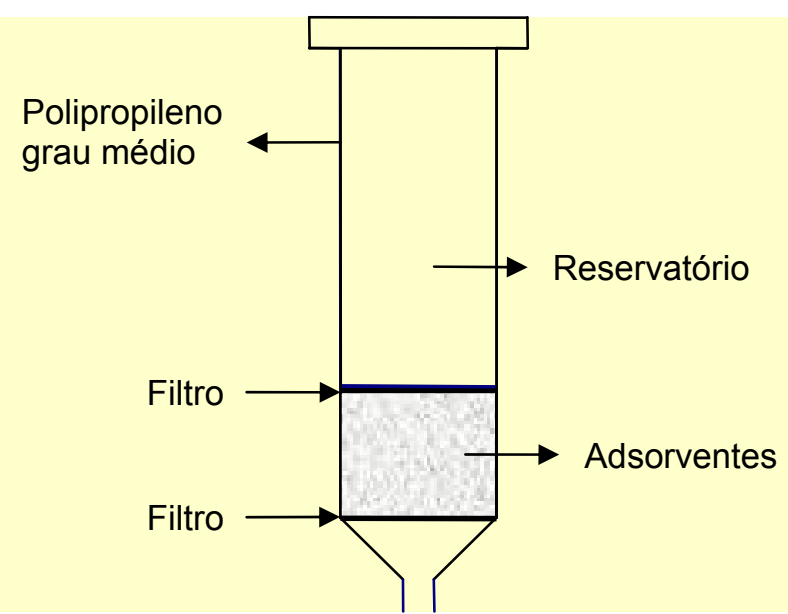

Figura 4: Cartucho típico empregado em extração em fase sólida (SPE).

Estudos como o de Laurence et al. (2001), mostram também que a cromatografia por imunoafinidade (IAC) também pode ser utilizada com o mesmo intuito da extração em fase sólida, para fazer um pré-tratamento da amostra, capaz de purificar e separar componentes da mesma.

\subsection{3 - Cromatografia em fase líquida}

O botânico russo Michail Semenovich Tswett foi o descobridor da cromatografia no início do século XX. Usou uma coluna de carbonato de cálcio para separar pigmentos de folhas arrastando-os com um solvente e separando-os numa série de bandas coloridas. Denominou-se assim o termo cromatografia (do grego kroma+graphia, o registro da cor). Depois de Tswett, muitos cientistas fizeram substanciais contribuições para o avanço da teoria e da prática da cromatografia e estima-se que atualmente cerca de $60 \%$ das análises feitas no mundo envolvem a cromatografia (DEGANI et al., 1997). 
A cromatografia é um método físico de separação dos componentes de uma mistura, realizada através da distribuição destes componentes entre duas fases, que estão em contato íntimo. Uma das fases permanece estacionária enquanto que a outra move-se através dela. Durante a passagem da fase móvel sobre a estacionária, os componentes da mistura são distribuídos entre as duas fases, de tal forma que cada um dos componentes é seletivamente retido pela fase estacionária, resultando em migrações diferenciais destes componentes (COLLINS et al., 1997).

$\mathrm{Na}$ cromatografia líquida, se a fase estacionária for um adsorvente sólido através do qual e por recurso a uma alta pressão se faz passar a fase estacionária e a amostra, temos a cromatografia líquida de alta pressão (CLAE), se a fase estacionária for um sólido iônico temos a cromatografia de troca iônica (IEC), se a fase estacionária for um sólido poroso fazendo-se a separação em função do tamanho molecular (sem interações entálpicas) tem-se a cromatografia de exclusão molecular (SEC). Caso particular deste tipo de cromatografia é a usada, por exemplo, no estudo de polímeros em que a fase estacionária é um gel, chamando-se por isso cromatografia de permeação de gel ou GPC.

As fases móveis utilizadas em CLAE devem possuir alto grau de pureza e estar livres de oxigênio ou outros gases dissolvidos, sendo filtradas e desgaseificadas antes do uso. A bomba deve proporcionar ao sistema vazão contínua sem pulsos com alta reprodutibilidade, possibilitando a eluição da fase móvel a um fluxo adequado.

As válvulas de injeção usadas possuem uma alça de amostragem para a introdução da amostra com uma seringa e duas posições, uma para o preenchimento da alça e outra para sua liberação para a coluna. Existem alças de 
diversos volumes, sendo utilizadas geralmente alças na faixa de 5- $50 \mathrm{~mL}$ para injeções analíticas.

O detector mais utilizado para separações por CLAE é o detector de ultravioleta, sendo também empregados detectores de fluorescência, de índice de refração, eletroquímicos, entre outros. Detectores de polarimetria para CLAE, recentemente desenvolvidos, diferenciam compostos quirais, através da rotação de seus estereoisômeros frente à luz plano-polarizada.

A versatilidade da técnica de cromatografia em fase líquida reside no grande número de fases estacionárias existentes, as quais possibilitam análises e separação de uma ampla gama de compostos com alta eficiência. A cromatografia tem sido utilizada em várias áreas da ciência, no acompanhamento de sínteses, em análises de pesticidas, feromônios, no isolamento de produtos naturais e sintéticos e na produção e controle de qualidade de medicamentos, dentre tantas outras aplicações.

As separações em CLAE podem se dar por adsorção, partição ou ambos. O suporte mais comumente utilizado é a sílica. O uso de fases estacionárias líquidas adsorvidas a um suporte não tem grande aplicação devido à perda de fase estacionária, mas o uso de suportes modificados, possibilita a produção de uma imensa variedade de colunas com diferentes propriedades e tipos de seletividade. As fases assim obtidas são chamadas de quimicamente ligadas. Essas fases, dependendo da modificação feita no suporte, podem atuar no modo normal, reverso ou ambos. Na cromatografia em fase normal, a fase estacionária é mais polar que a fase móvel, e em fase reversa, a fase móvel é mais polar (SCOTT, 1993).

As separações analíticas são predominantemente realizadas em fase reversa, sendo a fase C18 (octadecilsílica) a mais usada, ao passo que são preferidas fases 
que atuem no modo normal para fins preparativos, em vista de que separações no modo reverso utilizam fases móveis aquosas. Entre as fases quimicamente ligadas, merecido destaque deve ser dado às fases estacionárias quirais, as quais possibilitam a separação direta de enantiômeros. Para tanto, é necessária a presença de um seletor quiral como parte integrante da fase estacionária (SCOTT, 1993).

As colunas utilizadas em CLAE são geralmente de aço inoxidável, com diâmetro interno de cerca de $0,45 \mathrm{~cm}$ para separações analíticas e na faixa de 2,2 cm para preparativas. O comprimento é variável, sendo comuns colunas analíticas de 10- $25 \mathrm{~cm}$ e preparativas em torno de 25- $30 \mathrm{~cm}$. Essas colunas são reaproveitáveis, sendo empacotadas com suportes de alta resolução, não sendo necessária sua regeneração após cada separação (COLLINS et al, 1997).

Entre as técnicas modernas de análise, a cromatografia ocupa um lugar de destaque devido à sua facilidade em efetuar a separação, identificação e quantificação das espécies químicas, por todas estas qualidades, esta foi a técnica empregada nas análises do presente trabalho. Para garantir que os resultados das análises fossem reprodutíveis e confiáveis, o método estudado foi validado conforme os seguintes parâmetros: especificidade, limite de detecção, limite de quantificação, linearidade, precisão, exatidão, recuperação e robustez.

\section{6 - Validação de métodos analíticos}

A validação de um método é o processo de conseguir uma evidência documentada de que o mesmo é capaz de medir o que ele tem como finalidade medir. Pode-se ter confiança em resultados de uma medição, somente se utilizarmos um método cujas limitações são bem conhecidas, por isso a importância 
de se escolher bem os parâmetros que irão ser usados na validação de um método analítico.

\subsection{1 - Critério de aceitação}

Primeiro passo em uma validação consiste em estabelecer critérios de aceitação para cada um dos parâmetros determinados, esses critérios podem ser internamente ao laboratório, por norma ou por imposição do Órgão Fiscalizador ou Credenciador. No presente estudo, os critérios de aceitação utilizados foram os descritos no Guia de Validação de Métodos Bioanalíticos (ANVISA, 2003), por considerar que florações de cianobactérias são matrizes complexas.

\subsection{2 - Estabilidade}

As soluções têm que ser suficientemente estáveis durante o tempo de medição. É importante conhecer a estabilidade de amostras e padrões considerando diferentes temperaturas e quantidade de tempo. A quantificação é determinada e comparada com soluções novas, recém-preparadas. Se há algum problema de estabilidade, devem ser pesquisadas outras condições de estocagem ou aditivos. As amostras serão consideradas estáveis quando não se observar desvio superior à $15 \%$ do valor obtido das amostras recém-preparadas (ANVISA,2003).

\subsection{3 - Seletividade e Especificidade}

Um método específico é um método que produz uma resposta para um único analito, e um método seletivo é um método que produz uma resposta para um analito particular sem interferências de outros componentes na matriz. 
Para obter a seletividade, pode-se, por exemplo, analisar a matriz sem o analito, verificando que nenhum interferente acabe eluindo no tempo de retenção do analito de interesse, ou, se não houver possibilidade conseguir a matriz sem o analito, dopar a matriz com possíveis interferentes, ou utilizar a estatística: podem ser aplicados os testes $\mathrm{F}$ (Snedecor) de homogeneidades de variâncias e o teste $\mathrm{t}$ (Student) de comparação de médias. Ou ainda pode-se comparar as inclinações das curvas de adição de padrão, um grupo de amostras contendo a matriz e o outro grupo não incluindo a matriz. Se as curvas forem paralelas, o método é seletivo. A resposta de picos interferentes no tempo de retenção do analito de vê ser inferior a $20 \%$ da resposta da concentração do limite inferior de quantificação (LIQ) (ANVISA, 2003).

\subsection{4 - Limite de detecção}

A menor concentração de analito que produza uma resposta detectável acima do ruído do sistema é considerada como limite de detecção. É importante conhecer qual é a concentração mais baixa que pode ser detectada de maneira confiável pelo método.

O limite de detecção pode ser calculado de três maneiras diferentes: método visual, método relação sinal-ruído, método baseado em parâmetros da curva analítica. O método visual é utilizado para determinar o limite de detecção utilizando a matriz com adição de concentrações conhecidas da substância de interesse, de tal modo que se possa distinguir entre ruído e sinal analítico pela visualização da menor concentração visível (detectável). O método da relação sinal-ruído pode ser aplicado somente em procedimentos analíticos que mostram o ruído da linha de base. Para determinar a relação sinal-ruído, é feita a comparação entre a medição dos sinais de 
amostras em baixas concentrações conhecidas do composto de interesse na matriz e um branco (matriz isenta do composto de interesse) destas amostras. Assim, é estabelecida uma concentração mínima na qual a substância pode ser facilmente detectada. A relação sinal-ruído pode ser de 3:1 ou 2:1, proporções geralmente aceitas como estimativas do limite de detecção.

No método baseado em parâmetros da curva analítica, O limite de detecção (LD) pode ser expresso conforme a equação a seguir.

$$
L D=\frac{D P}{I C}
$$

onde DP é a estimativa do desvio padrão da resposta, que pode ser a estimativa do desvio padrão do branco, da equação da linha de regressão ou do coeficiente linear da equação e IC é a inclinação ("slope") ou coeficiente angular da curva analítica. Para calcular estes dados, uma curva analítica deverá ser feita utilizando a matriz contendo o composto de interesse na faixa de concentração próxima ao limite de detecção (RIBANI, 2004; ANVISA ,2003).

\subsection{5 - Limite de quantificação}

A menor concentração de analito que possa ser medida com exatidão e precisão aceitáveis, é considerada como limite inferior de quantificação.

Os mesmos critérios da determinação do limite de detecção podem ser adotados para a determinação do limite de quantificação, utilizando a relação 10:1 para métodos analíticos, por exemplo, (ANVISA, 2003), ou seja, o limite de quantificação pode ser calculado utilizando o método visual, a relação sinal-ruído ou a relação entre a estimativa do desvio padrão da resposta (DPR) (que pode ser a estimativa do desvio padrão do branco, da equação da linha de regressão ou do 
coeficiente linear da equação) e a inclinação da curva analítica (IC), em níveis de concentração próximos ao limite de quantificação, a partir da equação:

$$
L Q=10 \times \frac{D P}{I C}
$$

Para técnicas analíticas de separação, como as cromatográficas e eletroforéticas, os limites de detecção e de quantificação podem ser dados pela medição do ruído, mas não é trivial e às vezes subjetiva (já que a curva analítica é construída com a área e não somente o sinal do detector), e pode ser afetada pelas condições cromatográficas, como por exemplo, pelo tempo de uso da coluna cromatográfica. O método baseado nos parâmetros da curva analítica é considerado estatisticamente mais confiável nesses casos (RIBANI, 2004).

A relação sinal-ruído de 5 , para métodos bioanalíticos é considerada como aceitável para limites de quantificação, desde que o mesmo seja preciso e exato (ANVISA, 2003).

\subsection{6 - Linearidade}

A metodologia tem que provar que a resposta do analito é linearmente proporcional à concentração do mesmo na amostra, dentro de um intervalo especificado. São consideradas no mínimo, 5 níveis de concentração para permitir detectar alguma faixa não linear, por exemplo, de 80 a $120 \%$ da concentração-alvo, ou de 0,05 a 2,5\% em caso de concentrações baixas, em replicata (no mínimo, duplicata ou triplicata). Para métodos bioanalíticos, o Guia da ANVISA sugere no mínimo 6 concentrações diferentes de padrões para confeccionar a curva, soluçõespadrão que devem ser preparadas em uma matriz similar à da amostra, isenta da substância. Esse método de quantificação é determinado como superposição de 
matriz, e é utilizado para compensar o efeito da matriz, ou de possíveis interferentes e é de suma importância em determinações quando a matriz pode interferir na préconcentração, extração, separação ou detecção da substância de interesse (RIBANI et al., 2004).

Os resultados devem ser analisados por método estatistíco apropriado, como, por exemplo, a regressão linear pelo método dos mínimos quadrados. Deve-se apresentar a curva obtida, o coeficiente de correlação, intersecção com o eixo Y e o desvio padrão relativo. O critério mínimo aceitável do coeficiente de correlação (r) deve ser $=0,99$, para métodos analíticos e 0,98 para métodos bioanalíticos, (ANVISA, 2003).

\subsection{7 - Precisão}

A precisão pode ser contemplada a dois níveis, repetitividade e reprodutibilidade. A precisão expressa o grau de dispersão entre medições independentes a partir de uma mesma amostra, amostras semelhantes ou padrões sob condições definidas. As condições de repetitividade incluem, mesmo procedimento de medição, o mesmo observador, mesmo instrumento de medição, utilizado nas mesmas condições, mesmo local e repetições em curto período de tempo. A repetibilidade do método é verificada por, no mínimo, 9 (nove) determinações, contemplando o intervalo linear do método, ou seja, 3 (três) concentrações, baixa, média e alta, com 3 (três) réplicas cada. A precisão pode ser expressa como desvio padrão relativo (DPR) ou coeficiente de variação (CV\%), segundo a fórmula: 
DPR $\%=\quad$ Desvio Padrão $\quad \times 100$

Concentração média determinada

O valor máximo aceitável pode ser definido de acordo com a metodologia empregada, a concentração do analito na amostra, o tipo de matriz e a finalidade do método, não se admitindo valores superiores a 15\% (ANVISA, 2003).

\subsection{8. - Exatidão}

A exatidão pode ser determinada de três maneiras, uma analisando uma amostra de concentração conhecida (padrão) e comparando o resultado ao valor verdadeiro, outra comparando os resultados da análise pelo novo método ao resultado por um método de exatidão conhecida e dopando uma matriz branco com analito e calculando a taxa de recuperação das quantidades conhecidas de dopante. As amostras são feitas em triplicata, mínimo de três níveis de concentração (de 50 a $150 \%$ ou de 80 a 120\%) da concentração-alvo; ou, para impurezas, de 0,1 a 2,5\% de impureza. Quando a exatidão é feita no mesmo dia, é chamada (exatidão "intradia", ou "intracorrida") e em dias diferentes (exatidão "inter-dias" ou "intercorridas", no caso de cromatografia líquida, corrida analítica, por exemplo), (ANVISA, 2003).

$$
\text { Exatidão \% }=\frac{\text { Concentração média determinada }}{\text { Concentração teórica }} \times 100
$$

\subsection{9 - Robustez}

A robustez é a capacidade de um método permanecer inalterado frente a pequenas alterações nos parâmetros, como por exemplo, temperatura, tempo de 
extração, pH, concentração de tampão, volume de injeção, diferentes colunas, velocidade do fluxo, composição da matriz, proporção das fases móveis, etc. É uma indicação da confiabilidade do método durante seu uso normal.

\section{7 - Ensaio de Recuperação}

A recuperação está relacionada com a exatidão, pois reflete a quantidade de determinado analito, recuperado no processo, em relação à quantidade real presente na amostra. A exatidão é expressa como erro sistemático percentual, inerente ao processo. O erro sistemático ocorre pela perda da substância devido à baixa recuperação da extração, medidas volumétricas imprecisas ou substâncias interferentes na amostra. O estudo da recuperação consiste na "fortificação" da amostra, ou seja, na adição de soluções com diferentes concentrações do analito de interesse seguida pela determinação da concentração do analito adicionado.

\section{2 - Objetivos}

1 - Otimização das condições cromatográficas para a identificação e quantificação da cianotoxina, microcistina-LR, em amostras de floração de cianobactérias coletadas em pisciculturas situadas na região do Alto Mogi.

2 - Validação do método estudado para a determinação da microcistina-LR. 


\section{3 - Experimental}

\section{1 - Critério para a escolha dos estabelecimentos amostrados}

Os estabelecimentos que tiveram amostras coletadas foram aqueles que apresentaram evidências de florações de cianobactérias.

\subsection{1 - Características da área de estudo}

A bacia hidrográfica do Mogi Guaçu (Figura 6) está compreendida entre os paralelos $21^{\circ} 45^{\prime}$ e $22^{\circ} 45^{\prime}$, no Estado de São Paulo, com a região de nascentes localizada no Estado de Minas Gerais, no município de Bom Repouso e deságua no Rio Pardo, município de Pontal, São Paulo. Possui uma extensão de $473 \mathrm{Km}$, sendo $79,81 \%$ de sua extensão em São Paulo. Essa bacia abrange diretamente 50 cidades, sendo 12 municípios no Estado de Minas, com uma população de, aproximadamente, 149.255 habitantes, e 38 municípios no Estado de São Paulo, com uma população de, aproximadamente, 1.317.594 habitantes, segundo o IBGE. Os principais afluentes do rio Mogi Guaçu pela margem direita são os rios Oricanga, Itupeva, Cloro e Jaguari Mirim, e pela esquerda, Eleutério, do Peixe, do Roque, Quilombo e Mogi Mirim.

A bacia hidrográfica do Mogi Guaçu apresenta expressiva atividade agrícola desde a sua nascente até a sua foz, sendo responsável por grande parcela da produção agropecuária do estado de São Paulo. Nesse âmbito se destacam as culturas da cana-de-açúcar, laranja, braquiária, eucalipto, algodão, soja, amendoim, morango, batata e tomate. Além de todas as atividades antrópicas citadas, talvez a mais recente e em franco crescimento seja a indústria da piscicultura, que surge 
nesse quadro como atividade potencialmente impactante, que pode contribuir para a deterioração da qualidade das águas.

Para facilitar o planejamento e o controle dos afluentes da bacia hidrográfica do Mogi Guaçu em território paulista, a mesma teve a sua área de drenagem subdividida em macrorregiões ou macrozonas, pela Lei 7.641 de 19 de dezembro de 1991. Essa lei dispõe sobre as medidas de proteção ambiental e estabelece critérios para o uso e ocupação do solo da região compreendida pelas bacias dos rios Mogi Guaçu, Pardo e Grande, em uma tentativa de estabelecer diretrizes mais consistentes de localização para as atividades econômicas da área.

Nessa divisão, a bacia hidrográfica do Mogi Guaçu enquadrou-se como Unidade de Gerenciamento dos Recursos Hídricos 09 (UGRHI-09) e foi subdividida em compartimentos ambientais e econômico-ecológicos, com características e dimensões que possibilitassem seu planejamento e gestão, e a necessária relação entre os elementos do meio físico e os aspectos sócio-econômicos. A compartimentação definida foi composta pelas seguintes unidades: Alto Mogi $\left(4.054,9 \mathrm{Km}^{2}\right)$, Peixe $\left(1.143,1 \mathrm{Km}^{2}\right)$, Jaguari-Mirim $\left(1.516,5 \mathrm{Km}^{2}\right)$, Médio Mogi superior $\left(3.305,7 \mathrm{Km}^{2}\right)$ e Médio Mogi Inferior $\left(2.182,8 \mathrm{Km}^{2}\right)$.

As amostras de florações foram coletadas em pesque-pagues e pisciculturas da região do Alto Mogi, que compreende as cidades de Araras, Conchal, Engenheiro Coelho, Espírito Santo do Pinhal, Estiva-Gerbi, Leme, Mogi Guaçu, Mogi Mirim, Pirassununga e Santa Cruz da Conceição. E os estabelecimentos citados neste estudo serão denominados por letras como A, B, C, D e E, pois não foi autorizada a divulgação dos resultados das análises. 
A Figura 5 apresenta as bacias hidrográficas do estado de São Paulo, e a legenda das siglas utilizadas no mapa.

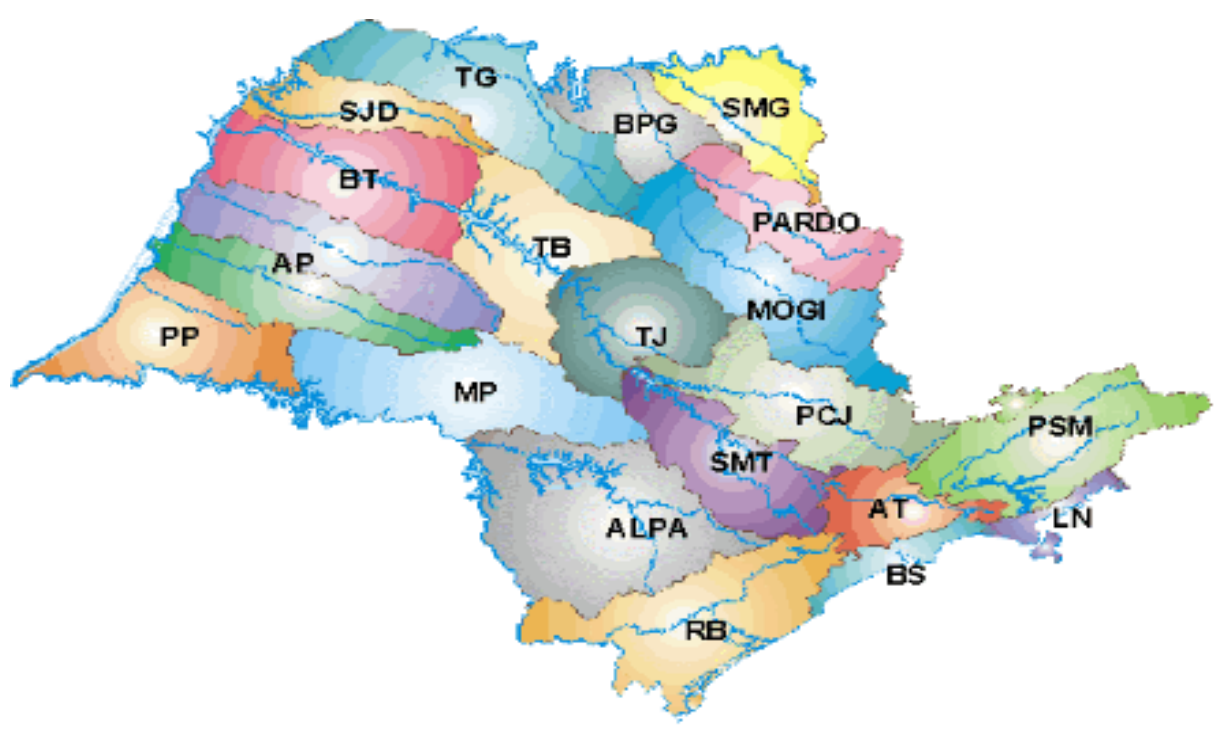

Figura 5: Bacias hidrográficas do estado de São Paulo.

Legenda figura 5:

\begin{tabular}{|l|l|}
\hline AT & BH do Alto Tietê \\
\hline LPA & BH do Alto Paranapanema \\
\hline AP & BH dos Rios Aguapeí e Peixe \\
\hline BPG & BH do Baixo Pardo / Grande \\
\hline BS & BH da Baixada Santista \\
\hline BT & BH do Baixo Tietê \\
\hline LN & BH do Litoral Norte \\
\hline MOGI & BH do Rio Mogi Guaçu \\
\hline MP & BH do Médio Paranapanema \\
\hline PARDO & BH do Pardo \\
\hline PCJ & $\begin{array}{l}\text { BHs dos Rios Piracicaba, Capivari e } \\
\text { Jundiaí }\end{array}$ \\
\hline PP & BH do Pontal do Paranapanema \\
\hline PSM & $\begin{array}{l}\text { BH do Rio Paraiba do Sul e Serra da } \\
\text { Mantiqueira }\end{array}$ \\
\hline RB & BH do Ribeira de Iguape e Litoral Sul \\
\hline SJD & BH do São José dos Dourados \\
\hline SMG & BHa do Sapucaí-Mirim / Grande \\
\hline SMT & BH dos Rios Sorocaba e Médio Tietê \\
\hline TB & BH do Tietê - Batalha \\
\hline TG & BH Turvo / Grande \\
\hline TJ & BH do Tietê-Jacaré \\
\hline & \\
\hline
\end{tabular}




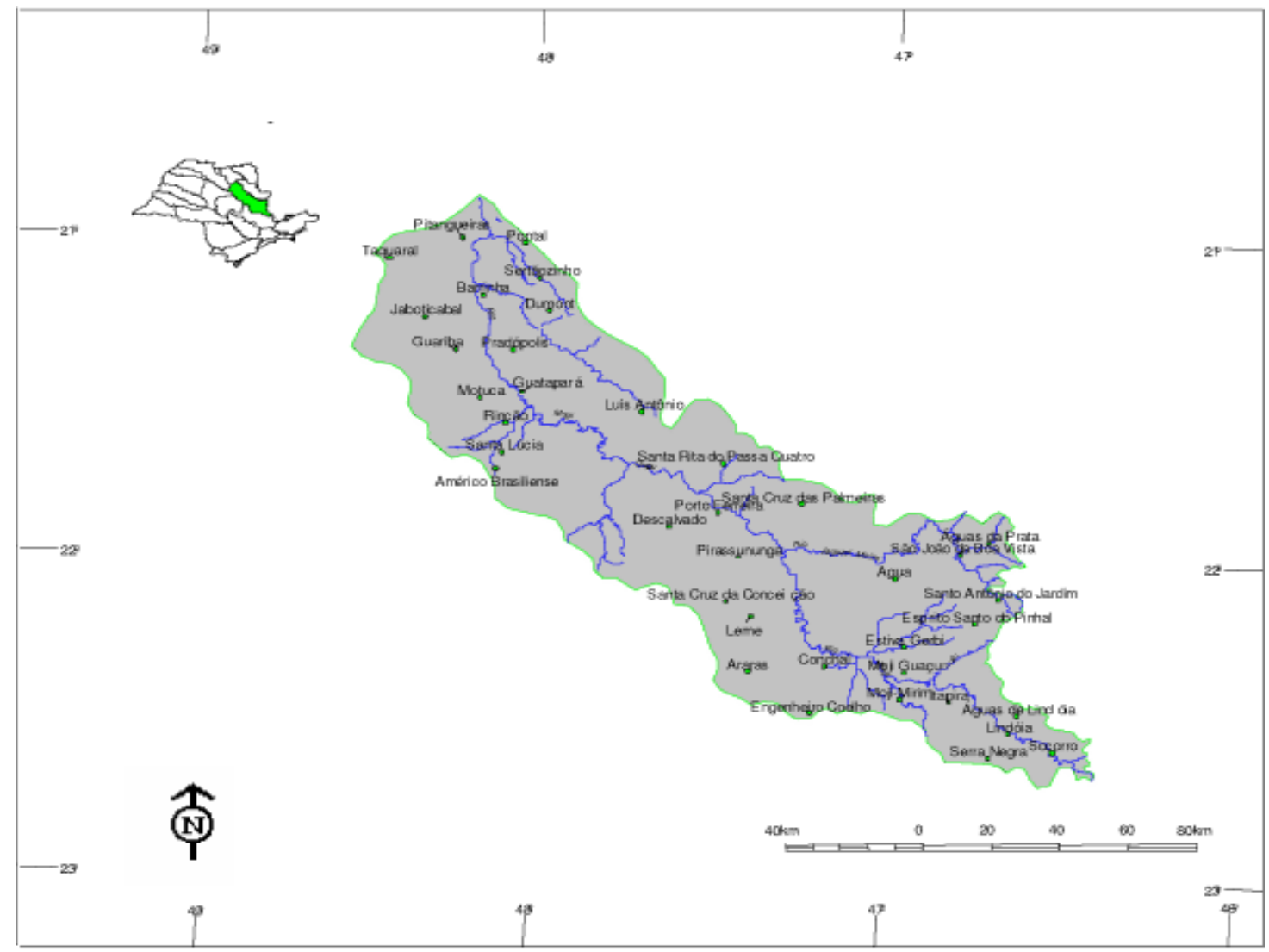

Figura 6: Localização da bacia hidrográfica do Mogi Guaçu (adaptada do Relatório Zero - CBHMOGI, Comitê de Bacia Hidrográfica do Mogi Guaçu, 1999).

\subsection{2 - Coleta das amostras de florações de cianobactérias}

As amostras das florações das cianobactérias foram coletadas cuidadosamente na superfície da água, com o auxílio de garrafa de Van Dorn, e foram mantidas à temperatura de $-4^{\circ} \mathrm{C}$. Logo após as coletas elas foram enviadas ao laboratório onde permaneceram congeladas enquanto não foram liofilizadas. Após a liofilização as amostras foram submetidas à extração e analisadas, conforme a data de chegada. $O$ liofilizador usado foi o da marca Edwards, modelo Modulyo. 


\section{2 - Preparação das amostras}

O fluxograma apresentado na Figura 7 relaciona todos os passos necessários à preparação das amostras.

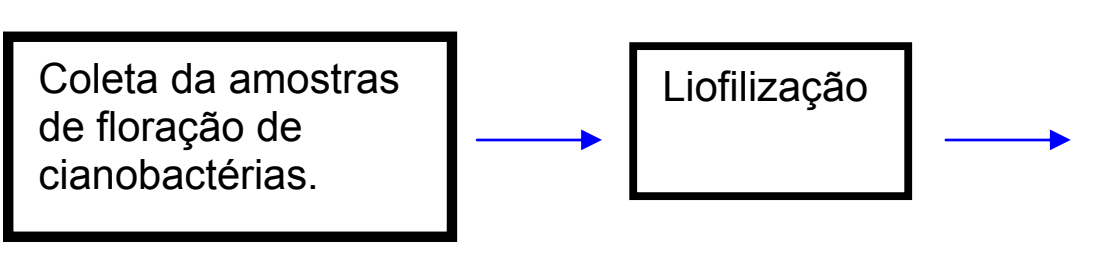

Adição de $1 \mathrm{~mL}$ de metanol acidificado ( $\mathrm{pH}$ 2) em 25mg de material liofilizado e sonicação durante 15 minutos.

O sobrenadante foi coletado e reservado. $\mathrm{E}$ ao resíduo sólido foi adicionado mais $1 \mathrm{~mL}$ de metanol acidificado ( $\mathrm{pH} 2$ ).
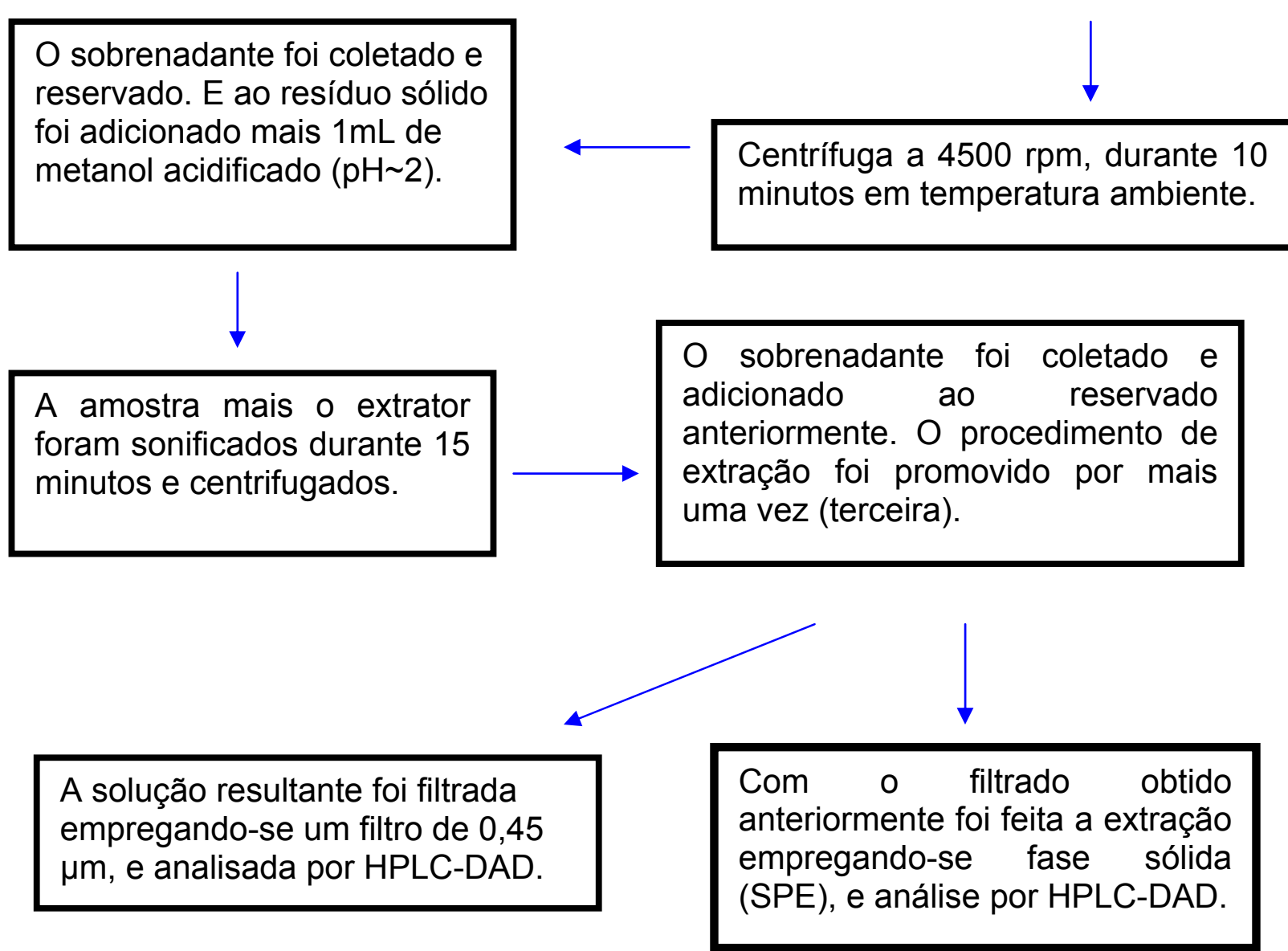

Figura 7: Fluxograma das etapas envolvidas na extração da microcistina-LR de amostras de florações. 


\section{3 - Procedimento da extração em fase sólida (SPE)}

\subsection{1 - Materiais}

\subsubsection{1 - Dados dos padrões de microcistina- LR}

- Microcistina-LR, da Microcystis aeruginosa, pureza aproximada de 95\%, marca: Sigma, código M2912, lote: C17K1021, frasco contendo 0,5 mg;

- Microcistina-LR, solução de $10 \mathrm{ug} \mathrm{mL}^{-1}$ em metanol, Sigma - Aldrich, lote: 6247X.

\subsubsection{2 - Dados do cartucho de SPE}

- Cartucho da marca J. T. Baker Bakerbond, cujo material adsorvente é o $\mathrm{C}_{18,} 500$ mg.

\subsection{2 - Método}

As proporções de metanol e água que foram utilizadas no condicionamento, lavagem e eluição do cartucho de C18, foram avaliadas conforme testes descritos em Resultados e aplicadas conforme as seguintes etapas, descritas na Figura 8.

- Composto de interesse

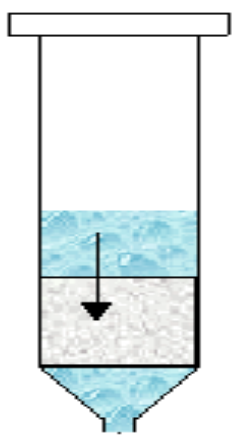

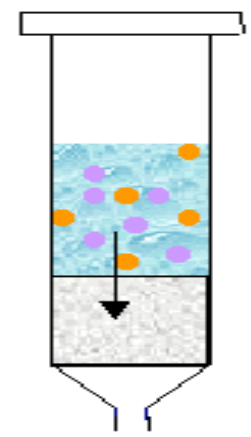

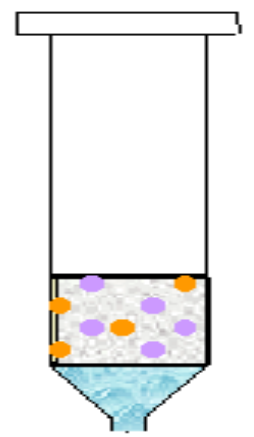

Contaminante
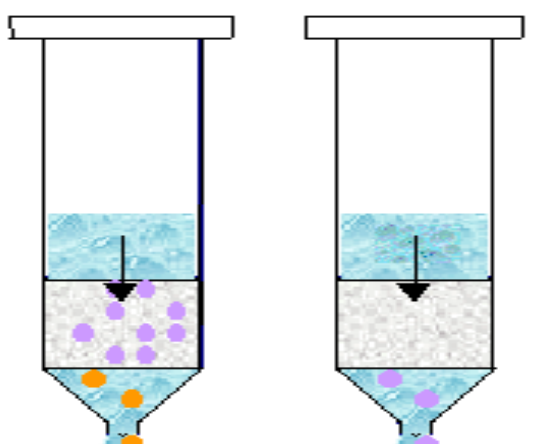

Figura 8: Etapas da extração em fase sólida. 
O cartucho foi condicionado com $10 \mathrm{~mL}$ de metanol acidificado com TFA ( $\mathrm{pH} 2$ ), seguido de $10 \mathrm{~mL}$ de água destilada, e após uma leve pressão a amostra passou através do filtro num fluxo de aproximadamente $4 \mathrm{~mL} \mathrm{~min}^{-1}$. O cartucho foi lavado com $10 \mathrm{~mL}$ de água destilada, e eluído com $10 \mathrm{~mL}$ de metanol acidificado com TFA ( $\mathrm{pH} \sim 2)$

\section{4 - Determinação cromatográfica da microcistina-LR}

\subsection{1 - Materiais}

\subsubsection{1 - Equipamentos}

Foram utilizados dois cromatógrafos em fase líquida, na primeira etapa do trabalho foi utilizado o da marca Shimadzu, instalado na Central de Análises Químicas Instrumentais, enquanto o equipamento da marca Agilent fosse adquirido e instalado no laboratório do grupo de Química Analítica Aplicada a Medicamentos e Ecossistemas Aquáticos e Terrestres, no Instituto de Química de São Carlos. Dados dos equipamentos:

- Cromatógrafo em fase líquida, marca: Agilent Technologies, série - 1200, composto por: injetor automático, bomba quaternária, degaseificador, forno e detector de arranjo de diodos (PDA). Software: ChemStation. (Figura 9).

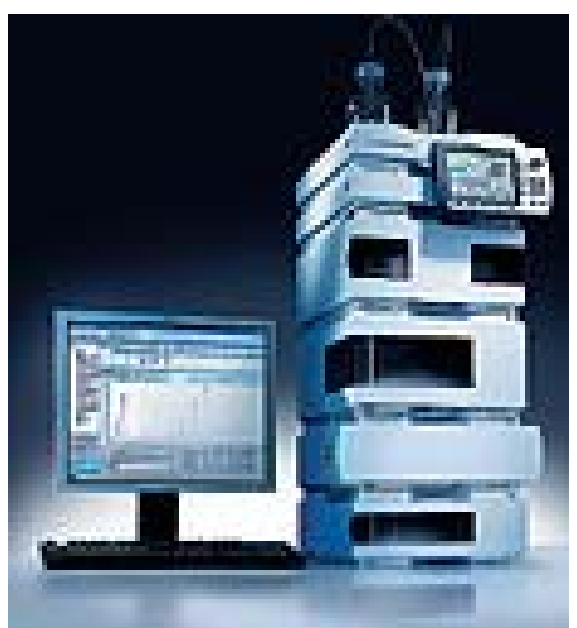

Figura 9: Foto ilustrativa do equipamento utilizado na validação do método. Marca: Agilent, Série 1200. 
- Cromatógrafo em fase líquida, marca: Shimadzu CBM-10A, sistema composto por duas bombas, injetor manual, detectores de Índice de Refração e UV-Vis (arranjo de diodos) e degaseificação da fase feita pelo gás hélio. Software: Class LC. A Figura 10 representa o sistema descrito.

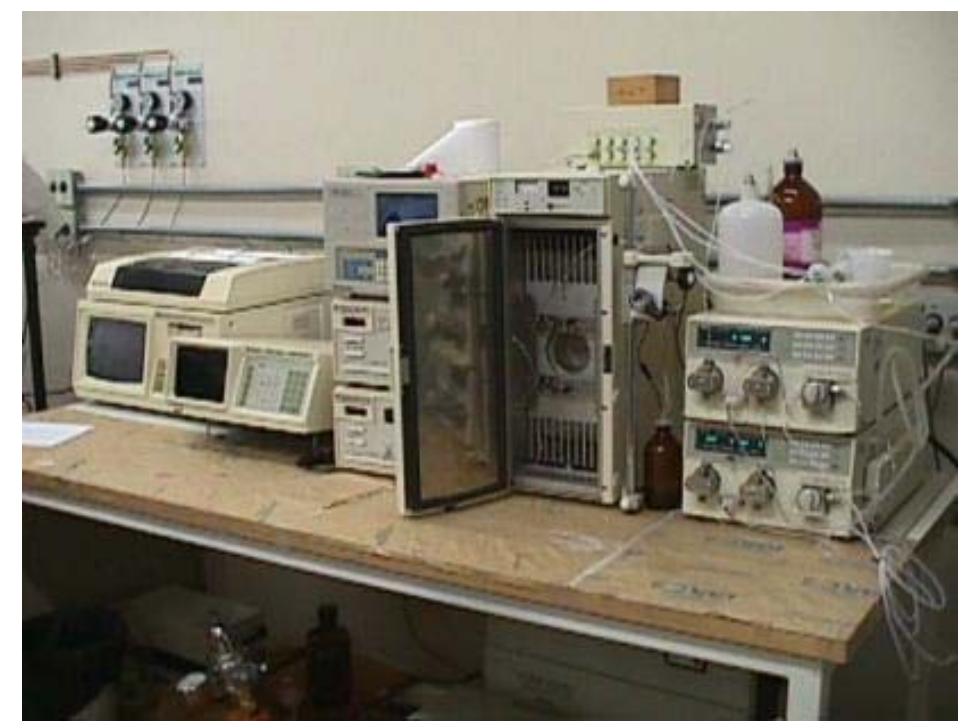

Figura 10: Foto ilustrativa do sistema utilizado na parte inicial desse estudo. Marca: Shimadzu, Modelo CBM -10 A. Equipamento instalado na CAQUI (Central de Análises Químicas Instrumentais).

\subsubsection{2 - Colunas cromatográficas}

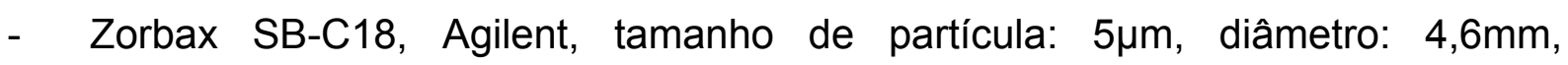
comprimento: 250mm, Part Number: 880975-902 e Serial Number: USCLO25047;

- Nucleosil C18, Mackaney-Nagel, tamanho de partícula: $5 \mu \mathrm{m}$, diâmetro: 4,6mm, comprimento: 200mm. Part number: 21306021/1352;

- Rexchrom C18 S5-100-ODS, Regis Pirkle, tamanho de partícula: 5um, diâmetro: 4,6mm, comprimento: $250 \mathrm{~mm}$. Part Number 728218.

\subsubsection{3 - Solventes}

- Acetonitrila, marca: J T Baker; 
- Metanol, marca: JT Baker;

- Ácido Trifluoracético (TFA), marca: Mallincrodt;

- Água ultrapura: Milli-Q (Millipore Corporation).

\subsection{2 - Método}

Todas as variáveis cromatográficas foram testadas, a fim de se encontrar as melhores condições para a análise da microcistina-LR em amostras de florações de cianobactérias coletadas em pesque-pagues e pisciculturas compreendidos na bacia hidrográfica do Mogi Guaçu. A Tabela 1 apresenta as variáveis testadas.

Tabela 1 - Variáveis testadas.

Variáveis
Coluna cromatográfica (diferentes composições de fases estacionárias)
Composições e proporções de solventes da fase móvel
Volume de injeção da amostra
Fluxo da fase móvel (mL minuto-1 $)$
Comprimento de onda (máximo de absorbância específica do analito)

\section{5 - Parâmetros utilizados na validação do método para a determinação da microcistina-LR em amostras de florações de cianobactérias}

Os fatores utilizados foram: especificidade, limite de detecção, limite inferior de quantificação, precisão, exatidão, linearidade, robustez e recuperação.

\subsection{1 - Especificidade}

A validação do método de análise desenvolvido para detectar e quantificar a microcistina-LR em amostras de florações de cianobactérias foi baseada na 
Resolução - RE n 899, de 29 de maio de 2003, da ANVISA, que possui como anexo - Guia para validação de métodos analíticos e bioanalíticos. No Guia, a especificação sobre a especificidade e sobre o limite de detecção propõe que sejam analisadas seis amostras de branco, nas condições pré-determinadas, e que se houver algum tipo de interferente que eluir próximo ou no mesmo tempo de retenção do analito, deve-se analisar mais seis brancos, e se em algum desses apresentar alguma interferência, que seja promovida alguma alteração no método para que esses interferentes possam ser eliminados ou separados com uma boa resolução. Foram analisadas seis amostras branco, de florações de cianobactérias, que não apresentaram nenhuma evidência da presença da microcistina-LR, estas foram utilizadas como base para a promoção de ajustes nas condições cromatográficas, de modo que o analito, microcistina- $L R$, eluísse em uma faixa de tempo que houvesse menos interferentes possíveis, lembrando que cada amostra de floração de cianobactéria, pode apresentar diferentes compostos, por se tratar de uma matriz muito complexa.

\subsection{2 - Limite de Detecção}

Freqüentemente parâmetros de Limites de Detecção (LD) são determinados em termos do desvio-padrão de medidas do branco. Entretanto, sendo o branco constituído de todos os reagentes, com exceção da amostra e do analito, não reproduz as mesmas condições a que o analito estará sujeito durante a análise. $\mathrm{O}$ LD determinado dessa forma pode avaliar mudanças ocorridas durante o desenvolvimento do método, ou para comparação de instrumentos. Entretanto, em relação à análise prática, esses valores são extremamente baixos e não representam a realidade. Por isso nesse estudo foi utilizada uma amostra real como 
matriz. O Limite de Detecção (LD) foi determinado utilizando a relação sinal-ruído proposta pela ANVISA, para métodos bioanalíticos, recomendando que o LD seja de 2 a 3 vezes superior ao ruído da linha de base. Essa razão foi calculada utilizando ferramentas do software ChemStation. Foi utilizado também, a critério de comparação, o método que é baseado nos parâmetros obtidos da curva analítica, conforme a equação:

$$
L D=\frac{D P}{I C} \times 3
$$

onde DP é a estimativa do desvio padrão da resposta, que pode ser a estimativa do desvio padrão do coeficiente linear da equação e IC é a inclinação ("slope") ou coeficiente angular da curva analítica.

\subsection{3 - Limite Inferior de Quantificação}

O critério utilizado para a determinação do LIQ (Limite Inferior de Quantificação), foi o também o proposto pela ANVISA, (2003), para métodos bioanalíticos, que é baseado na razão de 5:1 entre o sinal e o ruído da linha de base. E a critério de comparação, a relação entre a estimativa do desvio padrão (DP) da resposta dos coeficientes lineares das equações e as inclinações das curvas analíticas (IC), em níveis de concentração próximos ao limite de quantificação, conforme a equação:

$$
L I Q=10 \times \frac{D P}{I C}
$$

Após determinado o LIQ, foram preparadas cinco soluções-padrão na concentração de $0,5 \mu \mathrm{g} \mathrm{mL} \mathrm{m}^{-1}$, em uma matriz similar à da amostra, isenta de microcistina-LR, e essas soluções sonicadas e centrifugadas conforme o procedimento descrito em "Preparação das amostras" (Figura 7), para que houvesse 
uma maior correspondência com a composição da amostra. Essas soluções padrão foram analisadas quanto à precisão e exatidão.

\subsection{4 - Precisão e Exatidão Intra e Intercorridas}

Foram verificadas três concentrações da solução-padrão (baixa, média e alta) 1,5; 5,0; e 8,5 $\mu \mathrm{g} \mathrm{mL}^{-1}$, faixa que contempla a variação do procedimento, e para cada concentração foram feitas cinco determinações. Estas soluções também foram preparadas em uma matriz similar a da amostra, mas isenta de microcistina-LR, e expostas às etapas de extração da amostra. A exatidão e a precisão intercorrida foram analisadas dois dias após a intracorrida ter sido analisada. E um outro analista, membro do Grupo, preparou as amostras, conforme já descrito.

\subsection{5 - Linearidade}

A partir da solução padrão estoque de $10 \mu \mathrm{g} \mathrm{mL}^{-1}$, fez-se as diluições para as

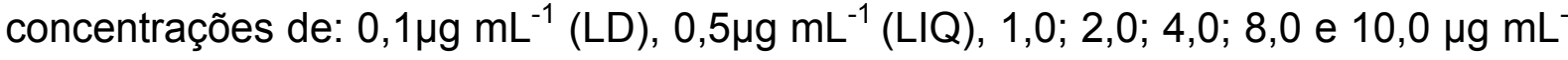
1. O diluente utilizado nessas soluções foi o extraído de uma matriz, branco, determinado no teste de especificidade. Estas soluções já prontas e de concentrações conhecidas passaram pelo mesmo processo de extração que as amostras reais, que consiste em etapas de sonicação e centrifugação, na mesma intensidade e quantidade das amostras, inclusive com transferência de eppendorf ${ }^{\circledR}$ (três vezes). Esse procedimento, baseado no Guia de Validação de Métodos Bioanalíticos, da ANVISA, (2003), foi adotado com o intuito de simular o método de extração para que os padrões possam estar nas mesmas condições da amostra, ou o mais próximo possível, minimizando erros na quantificação do analito, cujas áreas, 
se detectada a microcistina-LR, vão ser plotadas na curva analítica confeccionada com esses padrões. Esse método é classificado como Superposição de Matriz, e sua principal vantagem sobre o método de padronização externa é que fornece uma melhor correspondência com a composição da amostra, além de minimizar efeitos de matriz.

A faixa de concentração utilizada foi baseada em estudos de diferentes locais, mais em especial no trabalho de Watzin et al. (2008), que fez um estudo em longo prazo sobre o monitoramento da concentração da microcistina-LR em florações de cianobactérias na baia de Missisquoi, Quebec, Canadá, durante os anos de 2001 à 2005, onde encontraram valores equivalentes a $0,1 \mu \mathrm{g} \mathrm{mL}^{-1}$ à $6,5 \mu \mathrm{g} \mathrm{mL}^{-1}$.

\subsection{6 - Robustez}

O método foi avaliado quanto à pequenas alterações nos parâmetros cromatográficos, como alteração nas proporções da fase móvel, em $5 \%$ de solvente orgânico, acima e abaixo da proporção dita ideal, alteração no fluxo da fase móvel em 0,3 $\mathrm{mL} \mathrm{min}^{-1}$ a menos e 0,2 $\mathrm{mL} \mathrm{min}^{-1}$ a mais que o estipulado, de 1,5 $\mathrm{mL} \mathrm{min} \mathrm{m}^{-1}$, e foram avaliadas duas colunas diferentes.

\subsection{7 - Recuperação}

O procedimento adotado para a análise da recuperação foi o proposto pela ANVISA, (2003), para métodos bioanalíticos, onde há a comparação de padrões preparados sem passar pelo procedimento da extração, que representam $100 \%$ de recuperação, com os resultados analíticos de amostras extraídas a partir de três concentrações (baixa, média e alta), contemplando a faixa de linearidade do método. 
Para a determinação da porcentagem de recuperação, foram preparadas três soluções-padrão de microcistina-LR de cada concentração, 1,5; 5,0 e 8,5 $\mu \mathrm{g} \mathrm{mL}^{-1}$ utilizando o solvente, metanol acidificado com TFA, $\mathrm{pH} 2$, e as amostras reais foram preparadas dopando uma matriz, que foi analisada previamente e comprovada a ausência da microcistina-LR. Para quantificar as amostras foi utilizada a média das áreas dos padrões, conforme o cálculo:

$$
\% \operatorname{Rec}=\frac{A a \times[P d]}{A p \times[A]} \times 100
$$

Onde: $\mathrm{Aa}=$ área da amostra;

$A p=$ área do padrão (média três injeções);

$[\mathrm{Pd}]=$ concentração teórica do padrão;

$[\mathrm{A}]=$ concentração teórica da amostra.

\section{4 - Resultados e Discussões}

Os dados obtidos desde os primeiros testes à conclusão final, estão descritos nos tópicos à seguir.

\section{1 - Espectro de UV do padrão da microcistina-LR}

O equipamento utilizado foi o Espectrofotômetro Ultravioleta Visível Infravermelho Próximo (UVNis-NIR), Varian/Cary 5G, instalado na CAQUI (Central de Análises Químicas Instrumentais), no Instituto de Química de São Carlos. O espectro de UV da microcistina-LR foi obtido utilizando uma solução padrão de 10 $\mu \mathrm{g} \mathrm{mL} \mathrm{L}^{-1}$ em metanol acidificado com ácido trifluoracético, $\mathrm{pH} 2$ (solvente utilizado 
como branco), com o intuito de verificar a região de absorção máxima da mesma e o formato do espectro característico, assim como o apresentado na Figura 11.

O espectro de UV da microcistina-LR também pode ser obtido utilizando os softwares acoplados ao HPLC, por exemplo, o Class LC, software do equipamento da marca Shimadzu ou o Chemstation do equipamento da marca Agilent, é possível comparar os espectros de UV dos picos presentes no cromatograma da amostra de floração de cianobactérias, com o do padrão da microcistina-LR. A sobreposição dos espectros juntamente com a igualdade no tempo de retenção, indica a presença da toxina na amostra analisada.

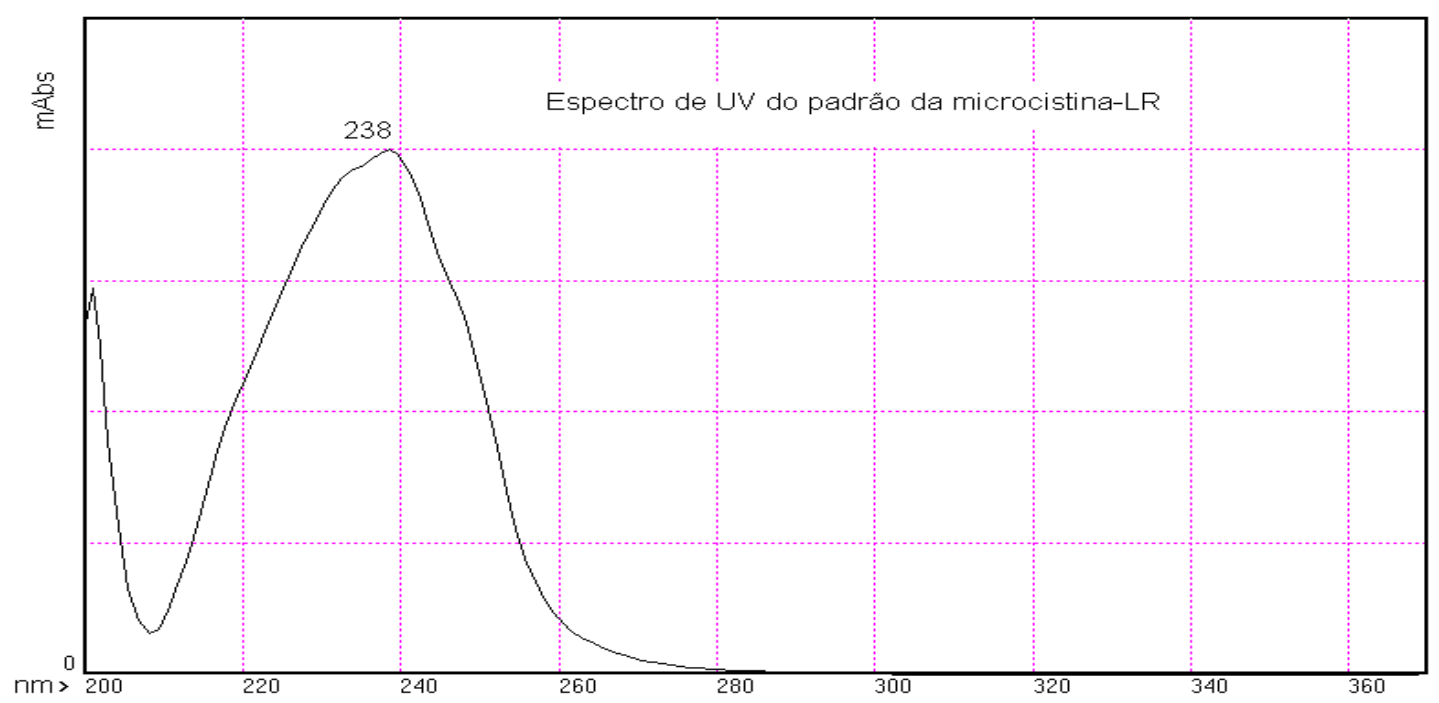

Figura 11: Espectro de UV do padrão da microcistina-LR. Espectrofotômetro Ultravioleta/ Visível Infravermelho Próximo (UV/Vis-NIR), Varian/Cary 5G.

\section{2 - Condições cromatográficas estudadas}

Com o intuito de diminuir ou extinguir possíveis fontes de erros na determinação e quantificação da microcistina-LR, facilitando assim a interpretação dos cromatogramas, durante o estudo foi necessário fazer testes de gradientes, colunas, fluxos, etc. Esse procedimento fez-se necessário, pois ao analisar as 
amostras de florações de cianobactérias no modo isocrático, foi observada a presença de alguns picos muito próximos ao tempo de retenção do padrão da microcistina-LR, podendo mascarar assim a determinação da mesma.

A composição e proporção da fase móvel foram as variáveis mais exploradas. A primeira fase testada foi a que é composta por tampão acetato de amônia $20 \mathrm{mM}$, pH 5, como fase aquosa e metanol como fase orgânica, uma proporção de 40:60 (fase A: fase B), no modo isocrático, foi considerada a melhor dentre outras proporções estudadas, tais como 28:72, 30:70, 35:65, 40:60 e 45:55. A proporção 40:60 foi considerada a melhor opção, pois, aplicando-a na análise de algumas amostras de florações, foi a que apresentou uma boa resolução dos picos e consequentemente uma maior seletividade. O tempo de retenção aproximado do pico referente à microcistina-LR nestas condições é de 6,6 minutos. A Figura 12 apresenta o cromatograma obtido nesta condição isocrática.

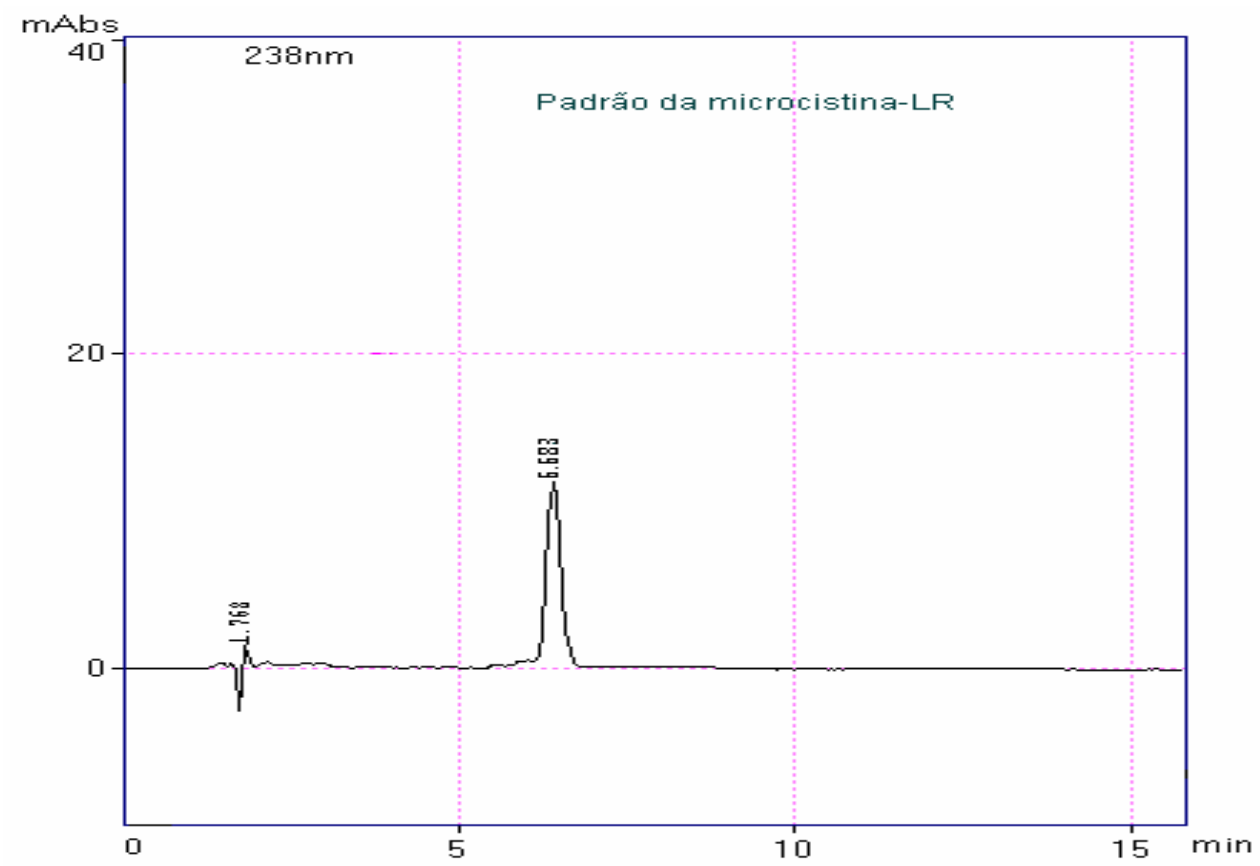

Figura 12: Cromatograma do padrão da microcistina-LR. Comprimento de onda $238 \mathrm{~nm}$, fase móvel 40:60 (Acetato de amônia 20 mM, pH 5 : Metanol), coluna $C_{18}$, da marca Rexchrom S5-100-ODS, com tamanho das partículas de $5 \mu \mathrm{m}, 150 \mathrm{~mm}$ de comprimento e 4,6 mm de diâmetro interno, volume de injeção de $20 \mu \mathrm{L}$ e fluxo de $1 \mathrm{~mL} \mathrm{~min}^{-1}$. Cromatógrafo Líquido da Shimadzu CBM-10 A. 
Outra proporção testada no modo isocrático foi a 55:45 usando metanol como fase orgânica e solução de ácido acético $0,1 \%$, como fase aquosa. Nestas condições de análise, o tempo de retenção aproximado do padrão da microcistinaLR é de 7,3 minutos.

A Figura 13 apresenta o cromatograma obtido com a proporção de 55:45 (metanol: ácido acético 0,1\%).

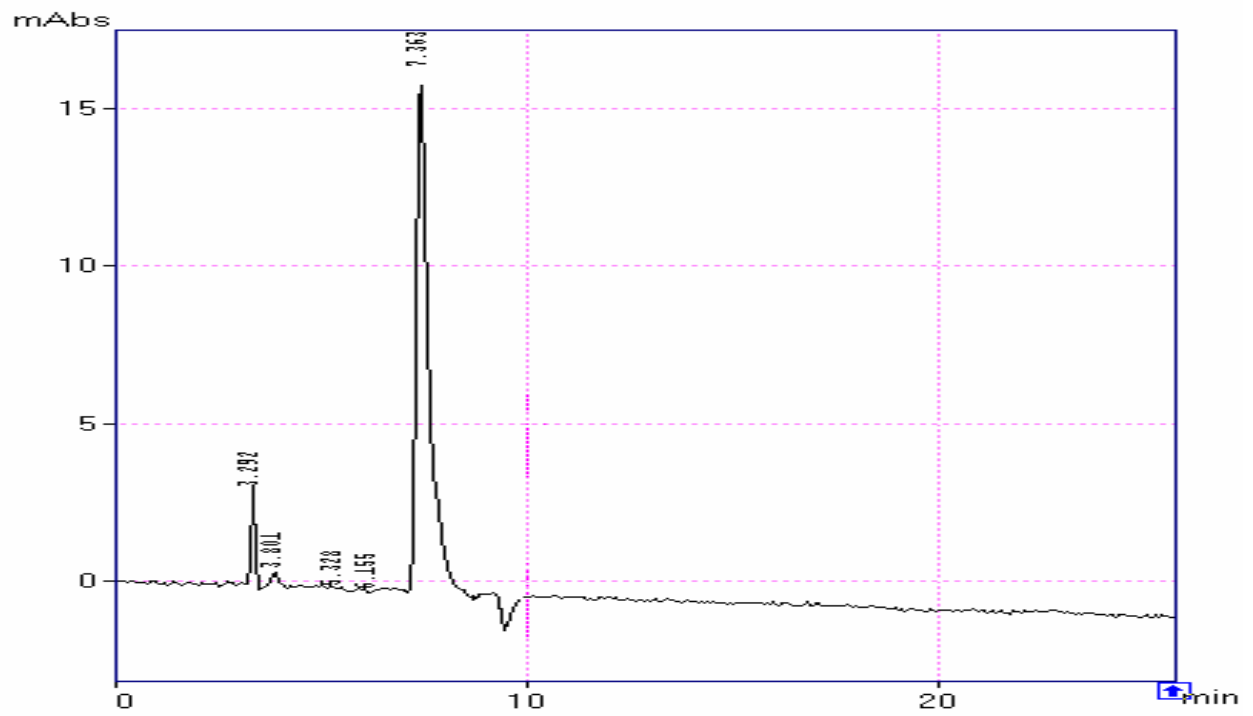

Figura 13: Cromatograma do padrão de microcistina-LR. Fase móvel metanol e ácido acético $0,1 \%$ (55:45), coluna C18, da marca Rexchrom S5-100-ODS, com tamanho das partículas de $5 \mu \mathrm{m}, 150$ $\mathrm{mm}$ de comprimento e 4,6 mm de diâmetro interno, volume de injeção de $20 \mu \mathrm{L}$ e fluxo de $1 \mathrm{~mL} \mathrm{~min}^{-1}$. Cromatógrafo Líquido da Shimadzu CBM-10 A.

Também foram estudados gradientes, com diferentes fases móveis, e diferentes proporções, visto que as características das amostras de florações podem variar significantemente.

Foram testados os solventes metanol: ácido acético $0,1 \%$ como fases móveis, na proporção de 35:65 (v/v), sendo que aumentou-se a proporção do metanol até 98:2 durante 35 minutos, permanecendo nessa condição por 5 minutos. $O$ retorno à fase inicial (35:65) foi de 15 minutos, e por mais cinco minutos permaneceu nessa proporção para um total equilíbrio da fase móvel, tempo total de análise, 60 minutos, conforme Tabela 2 . 
Tabela 2 - Proporção das fases móveis conforme o tempo de corrida, gradiente testado.

\begin{tabular}{c|cc}
\hline Tempo (minutos) & Fase $\boldsymbol{A}(\%)$ & Fase $\boldsymbol{B}(\%)$ \\
\hline 0 & 65 & 35 \\
35 & 02 & 98 \\
40 & 02 & 98 \\
55 & 65 & 35 \\
60 & 65 & 35 \\
\hline
\end{tabular}

A Figura 14 apresenta o cromatograma do padrão da microcistina-LR nas condições descritas anteriormente.

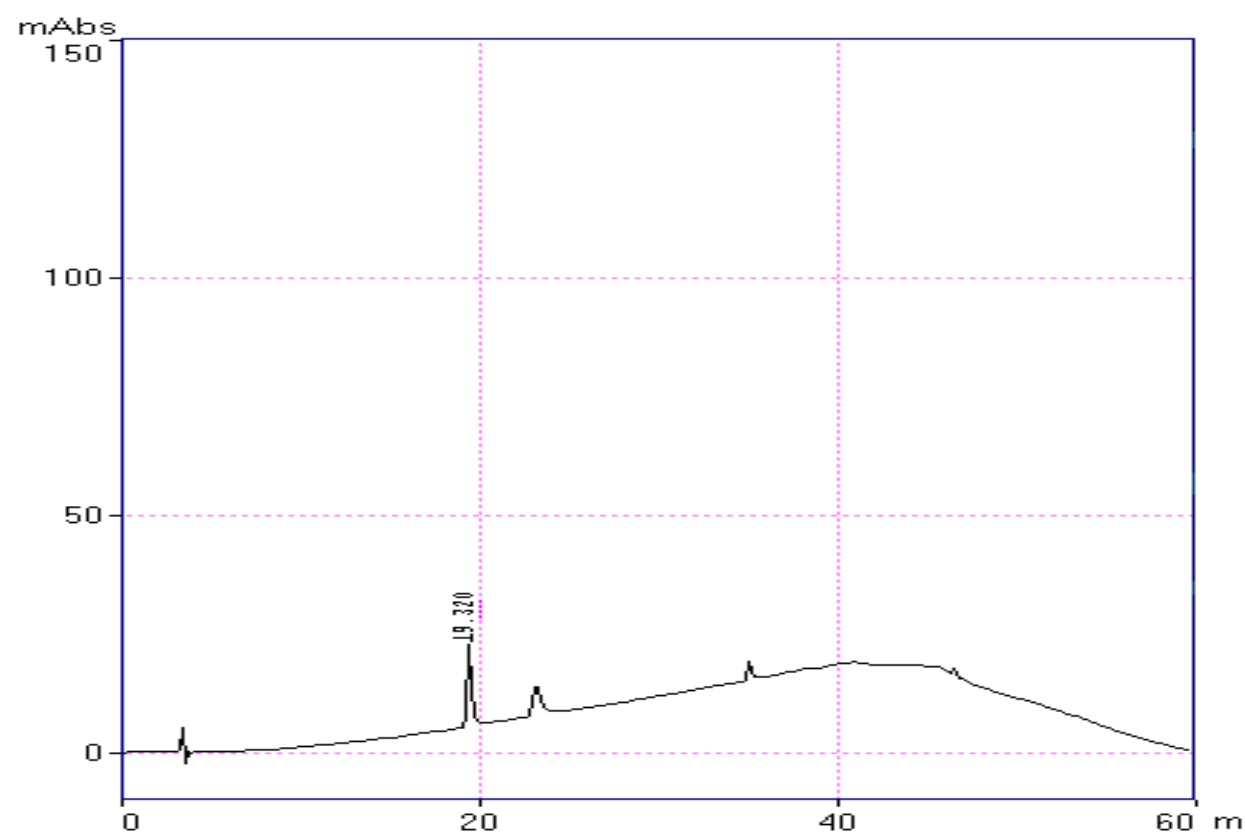

Figura 14: Cromatograma do padrão da microcistina-LR, obtido conforme o gradiente descrito anteriormente, com os solventes metanol e ácido acético $0,1 \%$ como fase B e A respectivamente. Coluna C18, da marca Rexchrom S5-100-ODS, com tamanho das partículas de $5 \mu \mathrm{m}, 150 \mathrm{~mm}$ de comprimento e 4,6 mm de diâmetro interno, comprimento de onda de $238 \mathrm{~nm}$, volume de injeção de $20 \mu \mathrm{L}$ e fluxo de $1 \mathrm{~mL} \mathrm{~min}^{-1}$. Cromatógrafo Líquido da Shimadzu CBM-10 A.

Como pode ser observado, nestas condições de análise, o tempo de retenção característico do padrão da microcistina-LR é de aproximadamente 19,3 minutos. Nos cromatogramas das amostras de extratos de florações de cianobactérias, foi observado que ainda persiste a presença de picos de interferentes no tempo próximo ao de retenção do analito. 
Com o intuito de otimizar as condições cromatográficas para a análise de florações de cianobactérias, um outro gradiente foi estudado, e foi baseado em análises de amostras de extratos de florações de cianobactérias. Foram analisadas oito amostras diferentes e as condições foram sendo alteradas de modo que a maioria dos picos dos interferentes que eluem num tempo próximo ao da microcistina-LR ficassem mais distantes, ou seja, com uma melhor resolução. Foi utilizado o solvente acetonitrila, como Fase B, orgânica, e água ultrapura como Fase A, aquosa, ambas com $0,05 \%$ de TFA (ácido trifluoracético), nas proporções descritas na Tabela 3. A coluna utilizada foi uma recém adquirida, da marca Agilent, Zorbax SB-C18, com tamanho de partícula de 5 um, 4,6 mm de diâmetro e $250 \mathrm{~mm}$ de comprimento.

Tabela 3 - Proporção das fases conforme o tempo de corrida. Utilizadas na validação.

\begin{tabular}{c|cc}
\hline Tempo (minutos) & Fase $\boldsymbol{A}(\%)$ & Fase $\mathbf{B}(\%)$ \\
\hline 0 & 70 & 30 \\
10 & 65 & 35 \\
35 & 30 & 70 \\
38 & 70 & 30 \\
41 & 70 & 30 \\
\hline
\end{tabular}

A coluna Zorbax SB-C18 apresentou um número bom de pratos teóricos, em torno de 80000 , e a simetria do pico da microcistina-LR ficou com 1,2; valor que está dentro da faixa considerada ideal, entre 0,8 e 1,5. A Figura 15 apresenta o cromatograma do padrão da microcistina-LR obtido nas condições descritas. 


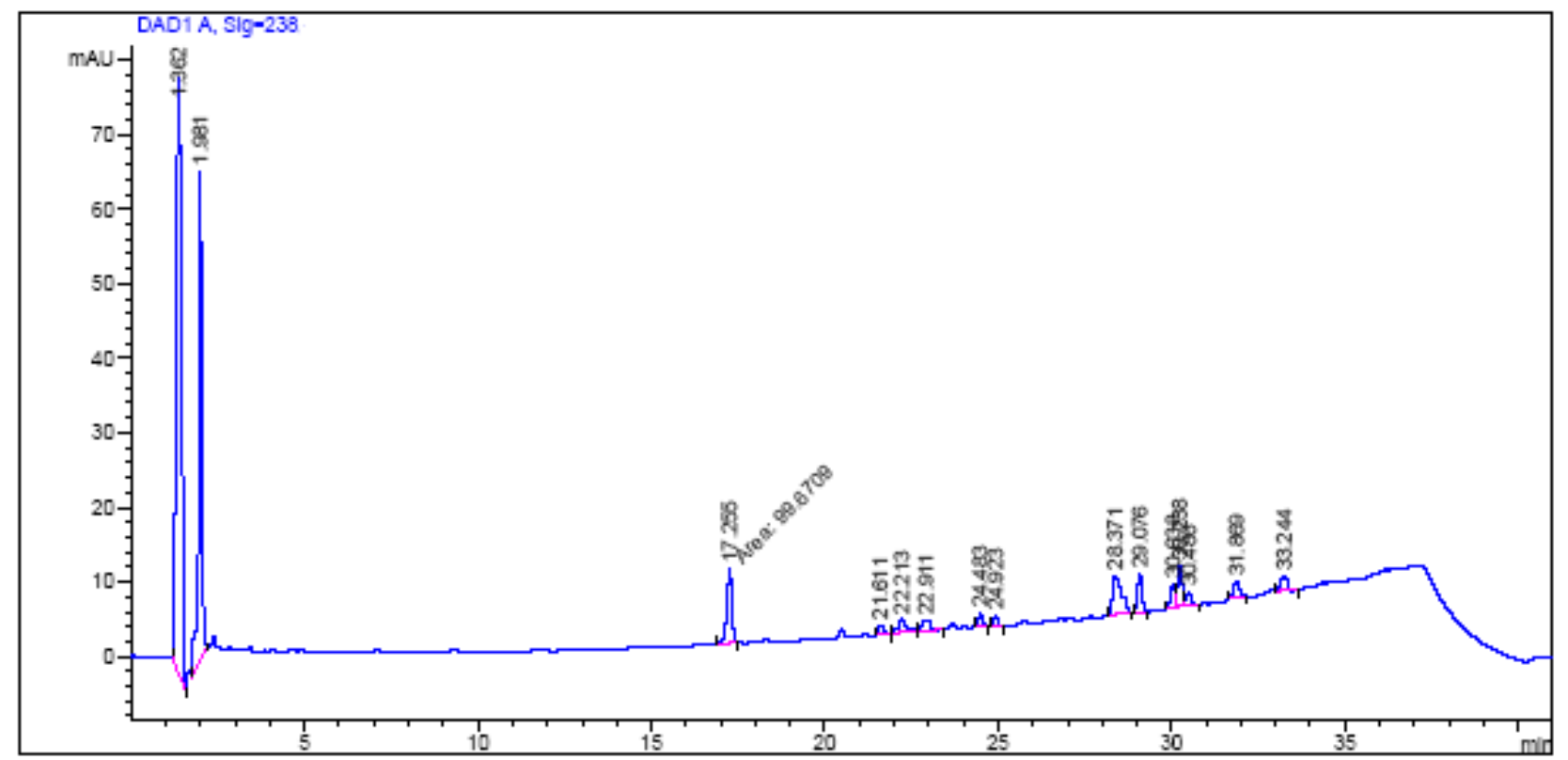

Figura 15: Cromatograma do padrão da microcistina-LR, obtido conforme o gradiente descrito na Tabela 5, coluna Zorbax SB-C18, Agilent, com tamanho de partícula de 5um, 250mm de comprimento e 4,6mm de diâmetro interno, volume de injeção de $20 \mu \mathrm{L}$, comprimento de onda de $238 \mathrm{~nm}$ e fluxo de $1,5 \mathrm{~mL} \min -1$. Cromatógrafo Líquido da Agilent Technologies. Condições utilizadas na validação do método analítico.

Apesar de o gradiente fazer com que a linha de base não fique estável durante toda a corrida, e de ser necessário promover uma corrida mais longa, em termos de tempo, ele se faz necessário por promover a eluição de interferentes que poderiam interferir na corrida subseqüente.

Os parâmetros descritos na Tabela 4 são os considerados ideais para a análise de amostras de florações de cianobactérias, quanto à determinação da microcistina-LR, e essas condições foram validadas conforme recomendações da ANVISA para métodos bioanalíticos. 
Tabela 4 - Condições cromatográficas utilizadas na validação do método.

\begin{tabular}{ll}
\hline Parâmetros & Descrição \\
\hline Coluna & Zorbax SB-C18, Agilent, 5um, 4,6x 250mm \\
Fase Móvel & Acetonitrila 0,05\% TFA: Água ultrapura 0,05\% TFA \\
Volume de injeção & $20 \mu \mathrm{L}$ \\
Fluxo da fase móvel & $1,5 \mathrm{~mL} \mathrm{~min}{ }^{-1}$ \\
Comprimento de onda & $238 \mathrm{~nm}$ \\
Temperatura da coluna & $25^{\circ} \mathrm{C}$ \\
\hline Equipamento (HPLC) & Agilent Technologies Série - 1200 \\
\hline
\end{tabular}

Outra coluna cromatográfica também foi avaliada nas condições descritas na Tabela 4, menos a marca da coluna, que é Nucleosil C18. O número de pratos teóricos obtido, cerca de 31000 , foi menor que o da coluna Zorbax, e a simetria do pico da microcistina-LR ficou igual ao limite máximo considerado, 1,5. Esses valores podem ser devido ao tempo de uso da coluna, que é maior que o da coluna Zorbax, e da diferença que existe entre os adsorventes das colunas de marcas diferentes, apesar das dimensões serem iguais. Os dados desse teste foram utilizados na avaliação da robustez do método desenvolvido. O tempo de retenção da microcistina-LR obtido com essa coluna foi de 16,5 minutos, conforme a Figura 16. 


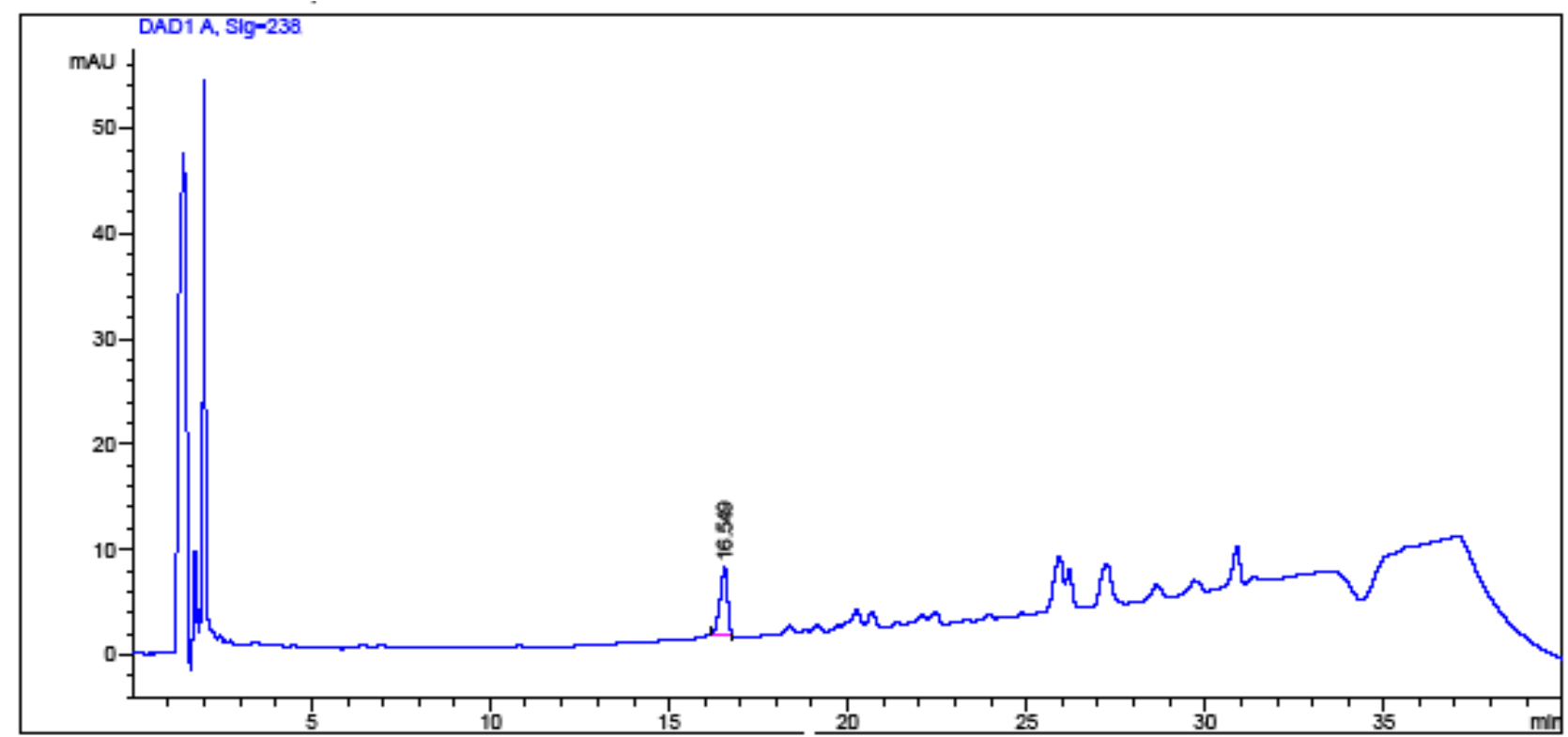

Figura 16: Cromatograma do padrão da microcistina-LR, obtido conforme o gradiente descrito na Tabela 5, coluna Nucleosil C18, com tamanho de partícula de $5 \mathrm{um}, 250 \mathrm{~mm}$ de comprimento e 4,6 $\mathrm{mm}$ de diâmetro interno, volume de injeção de $20 \mu \mathrm{L}$, comprimento de onda de $238 \mathrm{~nm}$ e fluxo de 1,5 $\mathrm{mL} \min ^{-1}$. Cromatógrafo Líquido da Agilent Technologies. Robustez - Troca de coluna.

Os solventes utilizados como fase móvel, acetonitrila e água, são ideais para análises de substâncias em que o comprimento de onda máximo é considerado baixo, em torno de $200 \mathrm{~nm}$, pois não interferem na análise.

O sistema utilizado na validação do método, o cromatógrafo da Agilent, possui um detector de arranjo de diodos acoplado, o que possibilita uma maior segurança quanto à determinação da microcistina-LR em amostras de florações de cianobactérias, pois a presença de um pico com o mesmo tempo de retenção do padrão da microcistina-LR no cromatograma da amostra, não prova que se trata realmente da toxina. Mas isso pode ser provado com a sobreposição dos espectros de UV, determinados pelo software ChemStation, conforme a Figura 17 que apresenta o pico do padrão da microcistina-LR, em destaque, seu espectro de UV , e a simetria do pico, relacionando sua pureza, que no caso, está com 99,9\%, o que significa que não há nenhum pico coeluindo com o analito em questão. Se a 
sobreposição dos espectros, da amostra e do padrão, for muito próxima, pode-se considerar provada a detecção da microcistina-LR na amostra.

Signal DAD1 A, Sig $=238$
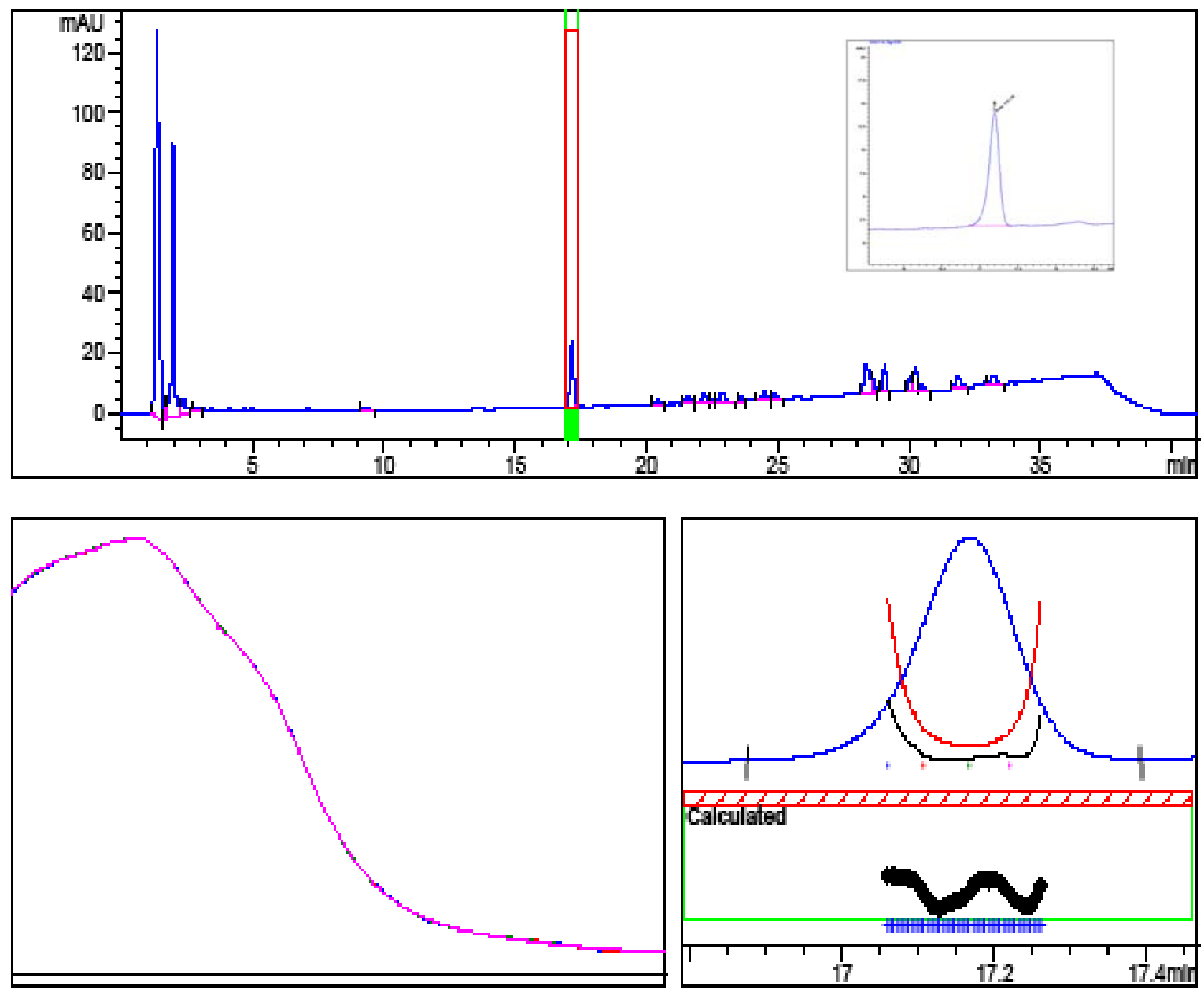

Figura 17: Espectros de UV do padrão da microcistina-LR obtido por meio do software Chemstation. A sobreposição do espectro do padrão com o espectro de um pico da amostra que saiu com o mesmo tempo de retenção do padrão, pode ser considerada uma contraprova para a indicativa da presença da toxina microcistina-LR, cuja absorção máxima é em $238 \mathrm{~nm}$.

\section{3 - Extração em Fase Sólida}

Muitos trabalhos relacionados à microcistina-LR descrevem a utilização da extração em fase sólida com o intuito de eliminar possíveis interferentes presentes na matriz de amostras, interferentes estes que poderiam mascarar ou subestimar resultados. Foram testadas proporções de água e metanol para condicionar o 
cartucho e também para a eluição do mesmo. Foram consideradas as melhores proporções, aquelas que no teste de recuperação apresentaram valores mais próximos de 100\%. Descrição das proporções estudadas (em resumo na Tabela 2):

O cartucho de $\mathrm{C} 18$ foi condicionado com $5,0 \mathrm{~mL}$ de água destilada, seguido de 5,0 mL de metanol, a amostra foi transferida para o cartucho, e após uma leve pressão a amostra passou através do filtro em um fluxo de aproximadamente 4 $\mathrm{mL} \mathrm{min}^{-1}$. Então o cartucho foi lavado com $5,0 \mathrm{~mL}$ de água destilada e na fase final, foi eluído com 5,0 mL de metanol.

O cartucho de C18 foi condicionado com 10,0 mL de metanol, seguido de 10,0 $\mathrm{mL}$ de água destilada; a amostra foi adicionada ao cartucho; e após uma leve pressão, a amostra passou através do filtro em um fluxo de aproximadamente 4 $\mathrm{mL} \mathrm{min}^{-1}$. O cartucho foi lavado com $10,0 \mathrm{~mL}$ de água destilada, e em seguida com $10,0 \mathrm{~mL}$ de metanol $10 \%$, e na fase final, o cartucho foi eluído com $10,0 \mathrm{~mL}$ de metanol.

O cartucho foi condicionado com $10,0 \mathrm{~mL}$ de metanol acidificado com TFA (pH 2), seguido de 10,0 mL de água destilada, e após uma leve pressão a amostra passou através do filtro em um fluxo de aproximadamente $4 \mathrm{~mL} \mathrm{~min}^{-1}$. $\mathrm{O}$ cartucho foi lavado com 10,0 mL de água destilada, e eluído com 10,0 mL de metanol acidificado com TFA ( $\mathrm{pH} 2)$

A Tabela 5 apresenta os testes feitos utilizando a extração em fase sólida. 
Tabela 5 - Solventes e proporções testadas para condicionamento, lavagem e eluição do cartucho de C18

\begin{tabular}{|c|c|c|c|c|}
\hline Teste & Condicionamento & $\begin{array}{c}\text { Passagem da } \\
\text { amostra }\end{array}$ & Lavagem & Eluiçao \\
\hline 1 & $\begin{array}{c}\text { 1- } 5 \mathrm{~mL} \text { de água } \\
\text { destilada } \\
2-5 \mathrm{~mL} \text { de metanol }\end{array}$ & $\begin{array}{l}\text { Fluxo aproximado } \\
\text { de } 4 \mathrm{~mL} \mathrm{~min}^{-1}\end{array}$ & $5 \mathrm{~mL}$ de água destilada & $\begin{array}{l}5 \mathrm{~mL} \text { de } \\
\text { metanol }\end{array}$ \\
\hline 2 & $\begin{array}{c}\text { 1- 10mL de água } \\
\text { destilada } \\
\text { 2- } 10 \mathrm{~mL} \text { de metanol }\end{array}$ & $\begin{array}{l}\text { Fluxo aproximado } \\
\text { de } 4 \mathrm{~mL} \mathrm{~min}^{-1}\end{array}$ & $\begin{array}{l}\text { 1- } 10 \mathrm{~mL} \text { de água } \\
\text { destilada } \\
\text { 2-10mL de metanol } 10 \%\end{array}$ & $\begin{array}{c}10 \mathrm{~mL} \mathrm{de} \\
\text { metanol }\end{array}$ \\
\hline 3 & $\begin{array}{l}\text { 1- 10mL de água } \\
\text { destilada } \\
\text { 2- 10mL de metanol } \\
\text { acidificado TFA }\end{array}$ & $\begin{array}{l}\text { Fluxo aproximado } \\
\text { de } 4 \mathrm{~mL} \mathrm{~min}^{-1}\end{array}$ & $10 \mathrm{~mL}$ de água destilada & $\begin{array}{l}10 \mathrm{~mL} \text { de } \\
\text { metanol } \\
\text { acidificado } \\
\text { TFA }\end{array}$ \\
\hline
\end{tabular}

Cada teste foi feito em triplicata, e esses testes foram avaliados por meio da porcentagem de recuperação de microcistina-LR após a dopagem de uma amostra de floração de cianobactéria com uma concentração conhecida de padrão (essa amostra foi previamente analisada, e foi descartada a possibilidade de haver a presença da microcistina-LR na mesma). A preparação das amostras consistiu em sonicar e centrifugar a floração liofilizada, conforme a extração descrita no fluxograma no item 3.2, "Preparação das amostras", porém antes de começar o procedimento da extração em fase sólida, um volume precisamente medido de amostra foi dopado com padrão de microcistina-LR afim de que a concentração final fosse de $2,5 \mu \mathrm{g} \mathrm{mL}^{-1}$. Foram preparados dois padrões também na concentração de $2,5 \mu \mathrm{g} \mathrm{mL}^{-1}$ para comparação de áreas. A média das áreas dos picos da microcitinaLR obtida nos cromatogramas desses padrões, que não foram extraídos em fase 
sólida, foi considerada como $100 \%$. Estes foram injetados três vezes cada, e a média e o desvio das áreas estão descritos na Tabela 6.

Tabela 6 - Porcentagem de recuperação de microcistina-LR após a aplicação da extração em fase sólida. Descrição dos testes vide Tabela 5.

\begin{tabular}{c|ccc}
\hline Teste & Média das áreas & Desvio - RSD (\%) & Recuperação (\%)* \\
\hline 1 & 77589,5 & 1,9 & 85 \\
2 & 80121,0 & 0,8 & 88 \\
3 & 82236,3 & 1,2 & 90 \\
\hline Padrão** $^{*}$ & 91524,2 & 1,5 & 100 \\
\hline
\end{tabular}

*media de três determinações

** média de seis injeções (três de cada padrão)

As análises de recuperação da extração em fase sólida foram feitas no cromatógrafo em fase líquida da Shimadzu CBM-10 A, nas condições descritas na Tabela 2.

Depois de analisar os resultados da extração em fase sólida nas amostras de florações de cianobactérias coletadas em pesque-pagues e pisciculturas da região do Alto Mogi, verificou-se que a extração pode ser necessária em alguns casos, por exemplo, em amostras com alto índice de interferentes, onde há extratos que coeluem com o analito, a microcistina-LR.

As Figuras 18 e 19 apresentam cromatogramas de uma amostra do extrato de floração de cianobactéria, que foi extraído conforme o fluxograma apresentado no item 3.2, "Preparação das amostras", porém uma fração final da amostra, mistura dos sobrenadantes, foi percolada por um cartucho de C18, conforme as condições descritas na Tabela 5, Teste 3 (melhor porcentagem de recuperação), e a outra foi filtrada diretamente em um filtro de poro de 0,45um (Millex), para comparar se na amostra que foi utilizada a extração em fase sólida, houve alguma diferença na eliminação de interferentes que coeluem com a microcistina-LR, ou eluem próximo do tempo de retenção da mesma. 


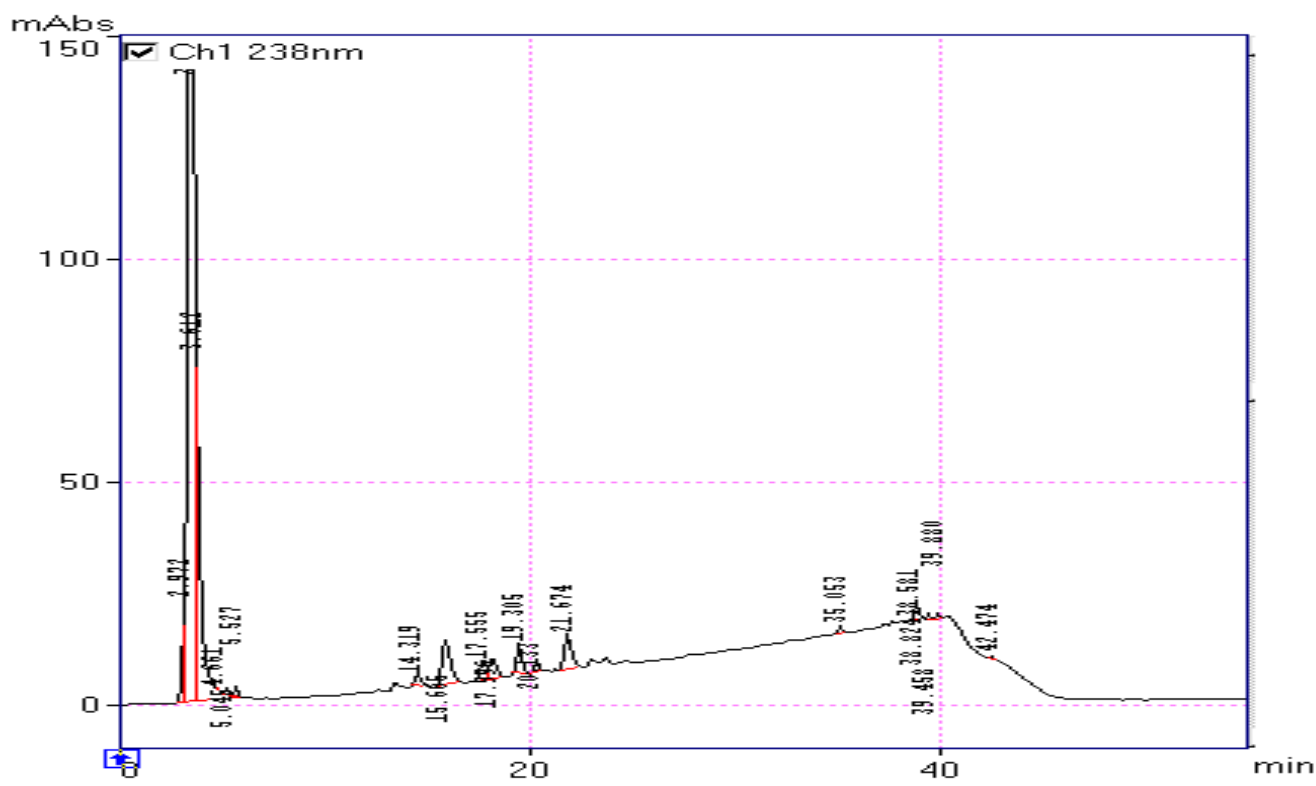

Figura 18: Cromatograma do extrato de floração de cianobactéria, filtrada em um filtro de poro de $0,45 \mu \mathrm{m}$. Coluna $\mathrm{C}_{18}$, da marca Rexchrom S5-100-ODS, com tamanho das partículas de $5 \mu \mathrm{m}, 4,6 \mathrm{x}$ $150 \mathrm{~mm}$, comprimento de onda de $238 \mathrm{~nm}$, volume de injeção de $20 \mu \mathrm{L}$ e fluxo de $1 \mathrm{~mL} \mathrm{~min}^{-1}$. Cromatógrafo Líquido da Shimadzu CBM-10 A. Gradiente utilizando metanol: ácido acético 0,1\% na proporção de 35:65 (v/v), sendo que aumentou-se a proporção do metanol até 98:2 durante 35 minutos, permanecendo nessa condição por 5 minutos. O retorno à fase inicial (35:65) foi de 15 minutos, e por mais cinco minutos permaneceu nessa proporção para um total equilíbrio da fase móvel, tempo total de análise, 60 minutos.

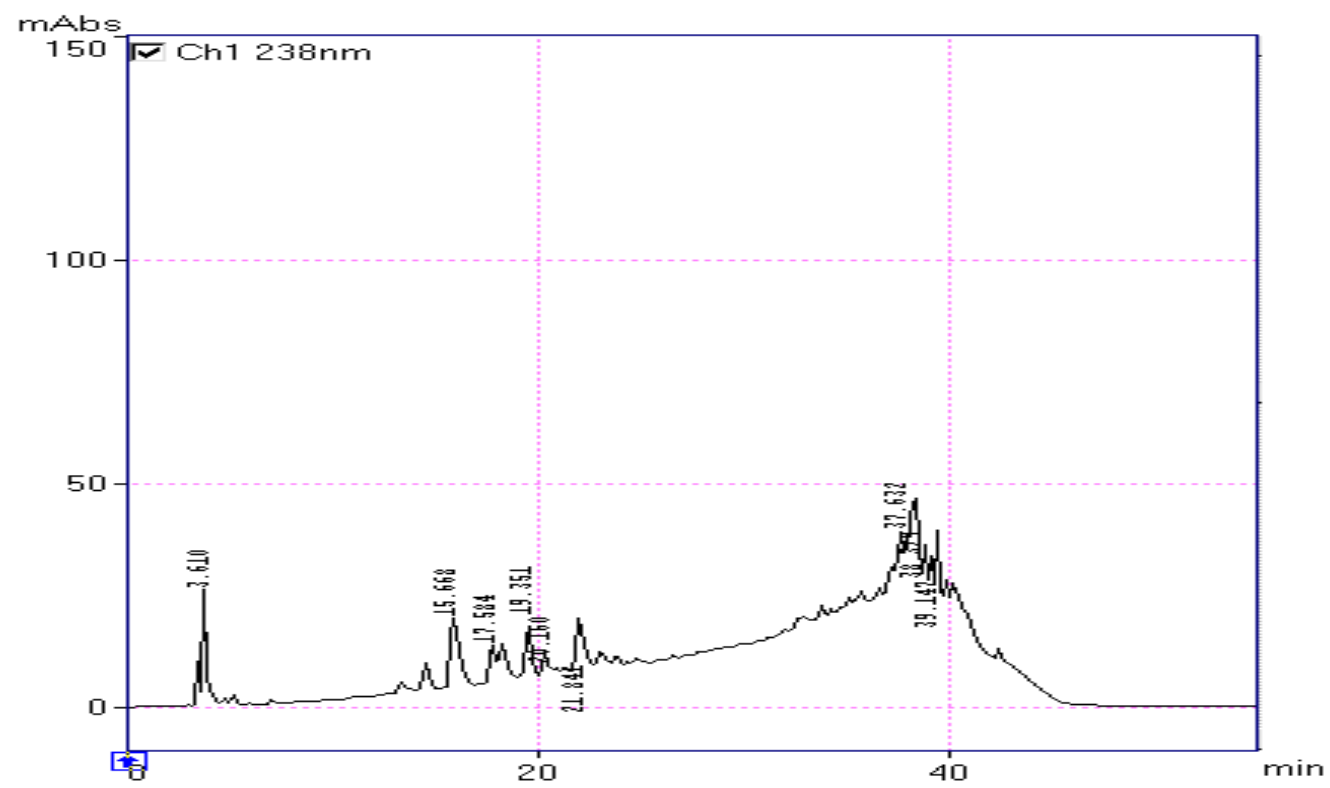

Figura 19: Cromatograma do extrato de floração de cianobactéria, percolada por um cartucho adsorvente de C18 (SPE). Coluna $\mathrm{C}_{18}$, da marca Rexchrom S5-100-ODS, com tamanho das partículas de $5 \mu \mathrm{m}, 4,6 \times 150 \mathrm{~mm}$, comprimento de onda de $238 \mathrm{~nm}$, volume de injeção de $20 \mu \mathrm{L}$ e fluxo de $1 \mathrm{~mL} \mathrm{~min}^{-1}$. Cromatógrafo Líquido da Shimadzu CBM-10 A. Gradiente utilizando metanol: ácido acético $0,1 \%$ na proporção de $35: 65(\mathrm{v} / \mathrm{v})$, sendo que aumentou-se a proporção do metanol até 98:2 durante 35 minutos, permanecendo nessa condição por 5 minutos. O retorno à fase inicial $(35: 65)$ foi de 15 minutos, e por mais cinco minutos permaneceu nessa proporção para um total equilíbrio da fase móvel, tempo total de análise, 60 minutos. 
Verifica-se pela Figura 19, que a presença de picos de interferentes que eluem próximos ao tempo de retenção característico da microcistina-LR, que nestas condições cromatográficas é de 19,3 minutos (vide cromatograma do padrão na Figura 14), mesmo após a extração em fase sólida, continuam presentes. Esse tipo de "clean-up", nesse caso, como não apresenta diferenças significativas quanto à eliminação de possíveis interferentes, pode ser eliminado. Esse estudo foi feito em mais duas amostras de extratos de florações de cianobactérias, coletadas em diferentes pisciculturas, e observou-se, que no caso de amostras de florações de cianobactérias, essa etapa da preparação da amostra, "clean-up", deve ser estudada a cada caso, conforme a dificuldade de detecção e de quantificação devido à presença de picos interferentes, uma vez que o aumento de etapas na preparação da amostra pode aumentar a probabilidade de erros analíticos e perda do analito em questão, devido à retenção do mesmo no cartucho, conforme dados da recuperação, Tabela 6.

\section{4 - Validação do método analítico de determinação e quantificação da microcistina- LR}

\subsection{1 - Especificidade}

Baseando-se na proposta do Guia de Validação de Métodos Bioanalíticos da ANVISA, foram analisadas amostras de florações de cianobactérias, e as amostras que não apresentaram nenhuma evidência da presença da microcistina-LR, foram utilizadas como base para a promoção de ajustes nas condições cromatográficas. De modo que o analito, microcistina-LR, eluísse numa faixa de tempo que houvesse menos interferentes possíveis, lembrando que cada amostra de floração de cianobactérias pode apresentar diferentes compostos, por se tratar de matrizes muito complexas. E após esses ajustes, utilizando as condições descritas nas 
Tabela 2 e 3, do item 4.2 "Condições cromatográficas estudadas", foram feitos o restante dos testes necessários para a validação do método analítico.

A Figura 20 apresenta o cromatograma obtido com a injeção do diluente (metanol acidificado), utilizado na extração das amostras liofilizadas de cianobactérias, onde pode ser observado que não há picos interferentes coeluindo próximo ao tempo de retenção do padrão da microcistina-LR, de 17,3 minutos (conforme cromatograma descrito na Figura 15), ou seja, nas condições determinadas para a validação do método, o diluente escolhido não interferirá nos resultados das análises.

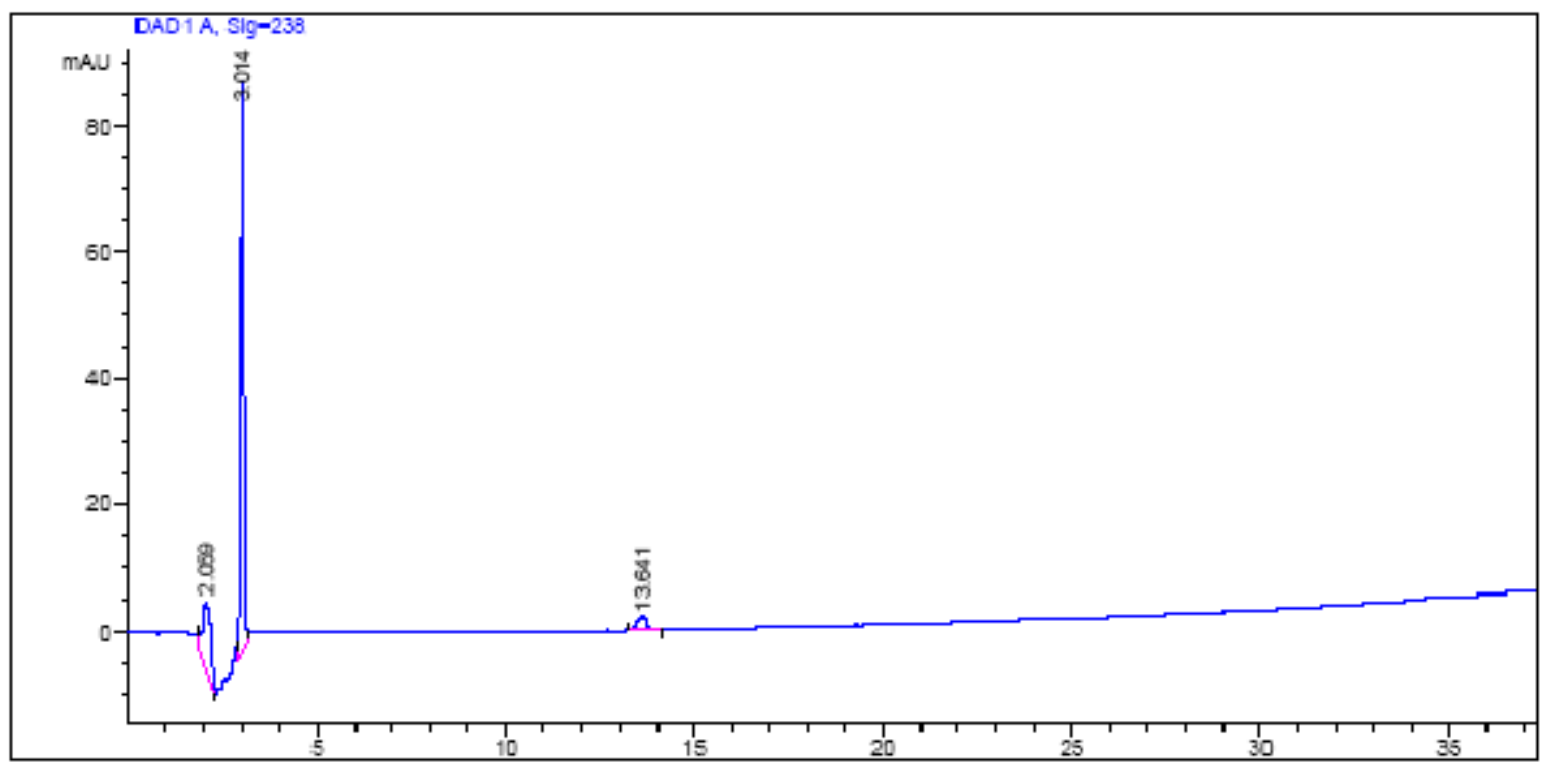

Figura 20: Cromatograma da injeção de 20 uL de diluente, metanol acidificado com TFA (pH 2). Obtido conforme o gradiente descrito na Tabela 2, coluna Nucleosil C18, com tamanho de partícula de $5 \mathrm{um}, 250 \mathrm{~mm}$ de comprimento e $4,6 \mathrm{~mm}$ de diâmetro interno, comprimento de onda de $238 \mathrm{~nm}$ e fluxo de $1,5 \mathrm{~mL} \mathrm{~min}^{-1}$.

A Figura 21 apresenta o cromatograma da injeção do extrato de uma amostra de floração, extraído conforme o fluxograma descrito no item 3.2, "Preparação das amostras", essa amostra foi utilizada como matriz (base) para a preparação das soluções padrões utilizadas em todos os testes envolvidos na validação do método analítico, principalmente na determinação do limite de detecção, por não apresentar nenhuma evidência da presença da microcistina-LR. A intenção é que essa matriz 
possa representar as dificuldades que pode-se encontrar na análise de amostras de florações de cianobactérias, podendo assim simular melhor as condições de análise, e minimizar erros.

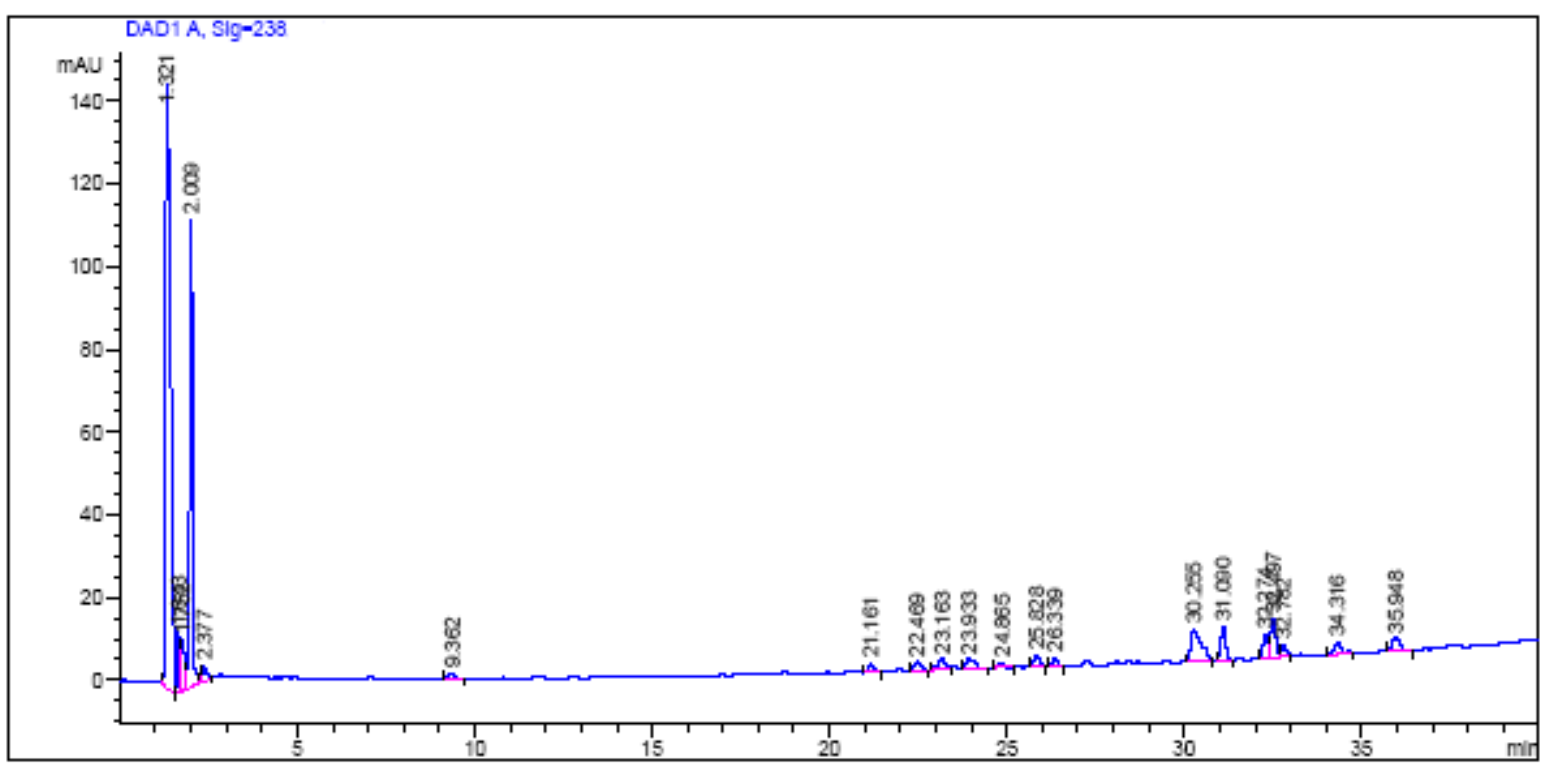

Figura 21: Cromatograma da injeção de 20uL da matriz (amostra de floração de cianobactérias que não foi detectada a microcistina-LR). Obtido conforme o gradiente descrito na Tabela 5 , coluna Nucleosil C18, com tamanho de partícula de $5 \mathrm{um}, 250 \mathrm{~mm}$ de comprimento e 4,6 mm de diâmetro interno, comprimento de onda de $238 \mathrm{~nm}$ e fluxo de $1,5 \mathrm{~mL} \mathrm{~min}^{-1}$.

\subsection{2 - Limite de Detecção}

O Limite de Detecção (LD) foi determinado utilizando a relação sinal-ruído proposta pela ANVISA, para métodos bioanalíticos, recomendando que o LD seja de 2 a 3 vezes superior ao ruído da linha de base. 


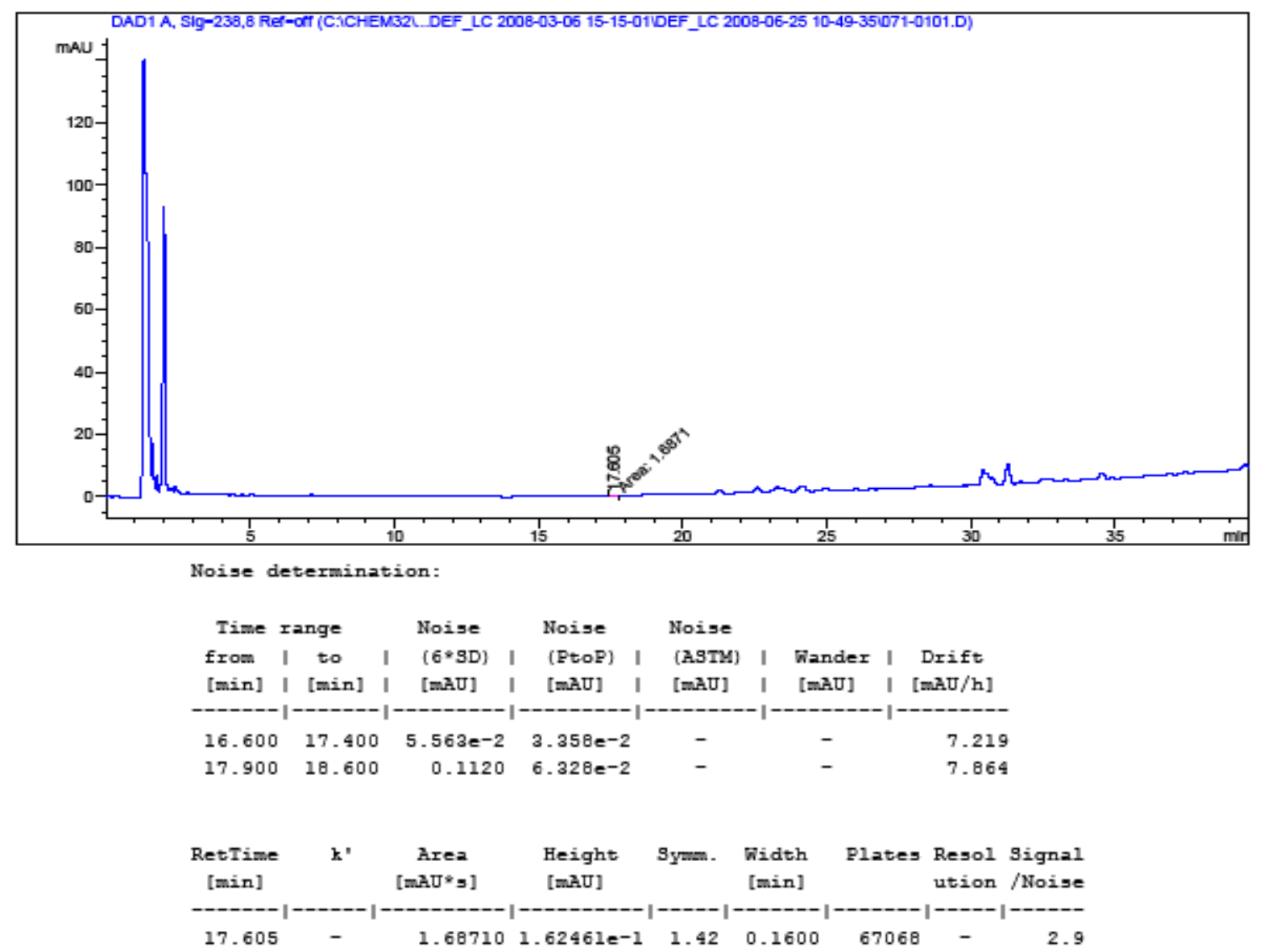

Figura 22: Cromatograma do padrão da microcistina-LR na concentração de $0,1 \mu \mathrm{g} \mathrm{mL}{ }^{-1}$, limite de deteç̧ão (LD), determinado pela razão sinal-ruído. Para o cálculo do ruído da linha de base, foi considerado o intervalo de 1 minuto, antes e após o tempo de retenção do padrão, de 17,6 minutos.

Como pode ser observado na Figura 22, o valor sinal-ruído obtido com a solução-padrão de $0,1 \mu \mathrm{g} \mathrm{mL} \mathrm{mL}^{-1}$ foi de 2,9. Esse valor foi calculado utilizando o ruído da linha de base próximo ao tempo de retenção da microcistina-LR. Foi considerado o tempo de 1 minuto antes e após o tempo de retenção do analito, visto que em um dia inteiro de corridas subsequentes, o máximo que o tempo de retenção do analito variou foi de 0,5 minutos. Um dos fatores que poderiam influenciar em uma maior variação de tempo de retenção, seria a mudança de temperatura na sala onde está instalado o equipamento, e consequentemente na coluna e na fase móvel, porém a sala onde está instalado o equipamento possui ar condicionado, e a temperatura é monitorada. Outro fator que poderia influenciar é a qualidade dos solventes e a preparação das fases móveis, que devem ser cuidadosamente preparadas. 
O limite de detecção também foi calculado utilizando os parâmetros obtidos a partir da curva analítica da resposta das áreas dos padrões "versus" a concentração dos mesmos, e o valor encontrado foi menor que o encontrado através da relação sinal-ruído, 0,03 $\mu \mathrm{g} \mathrm{mL}-1$, porém o valor considerado foi o maior, de $0,1 \mu \mathrm{g} \mathrm{mL}^{-1}$, como precaução, por se tratar de uma matriz complexa, que pode apresentar muitos interferentes diferentes.

\subsection{3 - Limite Inferior de Quantificação (LIQ)}

O critério utilizado para a determinação do LIQ, foi também o proposto pela ANVISA, (2003), no guia de validação para métodos bioanalíticos, que é baseado na razão de 5:1 entre o sinal e o ruído da linha de base, pois esse valor deve ser cinco vezes superior a qualquer interferência da amostra branco no tempo de retenção do analito.

E a relação entre a estimativa do desvio padrão da resposta (DP) do coeficiente linear da equação e a inclinação da curva analítica (IC), em níveis de concentração próximos ao limite de quantificação, foi utilizada em termos de comparação, a partir da seguinte equação:

$$
L I Q=10 \times \frac{D P}{I C}
$$

O resultado obtido foi menor que o encontrado através da relação sinal-ruído, $0,11 \mu \mathrm{g} \mathrm{mL}{ }^{-1}$, porém assim como para a determinação do limite de detecção, preferiuse utilizar os maiores valores, visto que tanto o LD quanto o LIQ podem ser afetados pelas condições cromatográficas. O tempo de uso da coluna e/ou o seu condicionamento, por exemplo, podem influenciar na relação sinal-ruído, podendo tanto aumentar como diminuir o LD e consequentemente o LIQ. 
O cromatograma a seguir, Figura 23, representa a resposta de um padrão de microcistina-LR na concentração do LIQ, 0,5 $\mu \mathrm{g} \mathrm{mL}^{-1}$.
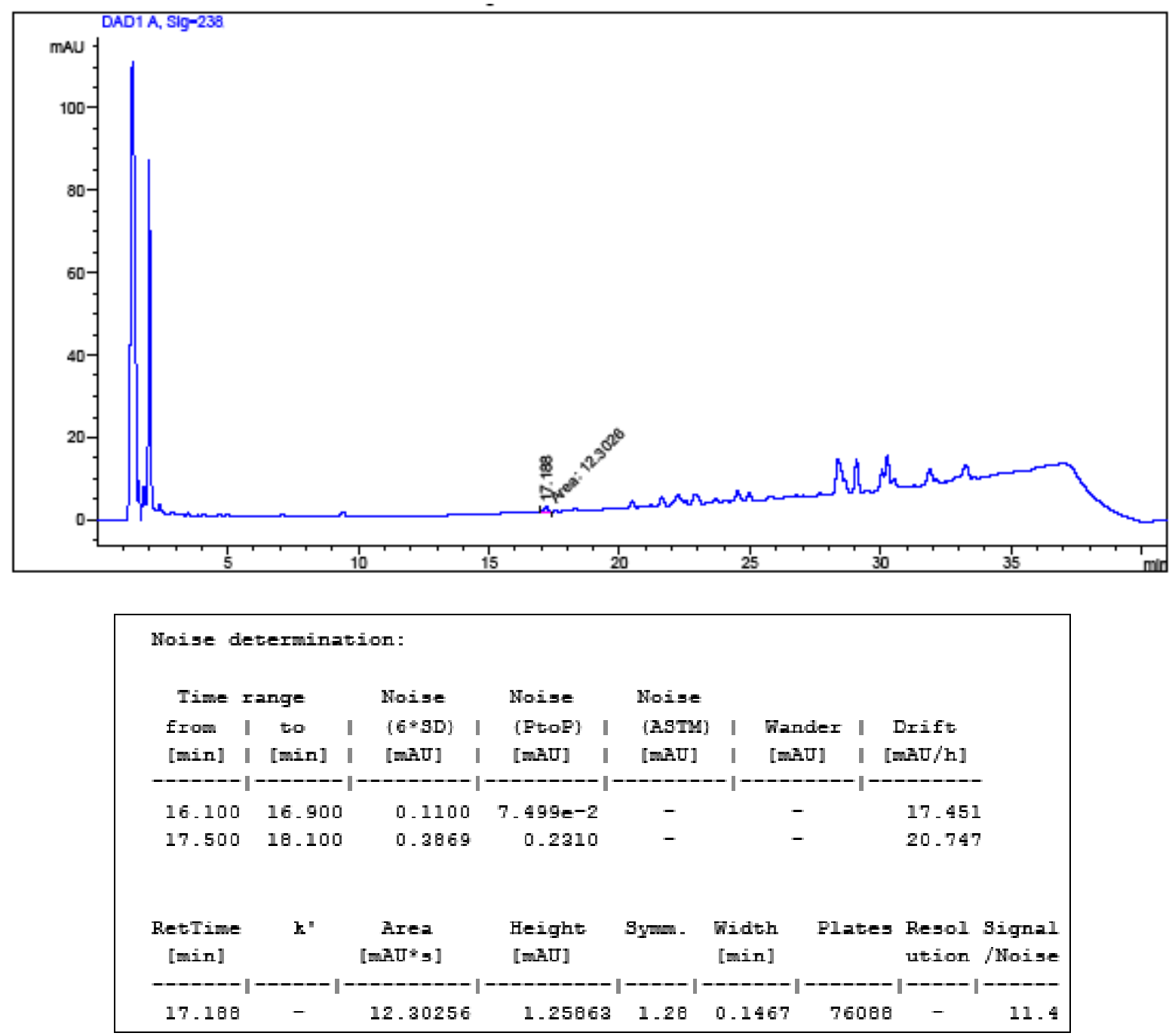

Figura 23: Cromatograma do padrão da microcistina-LR, $0,5 \mu \mathrm{g} \mathrm{mL}^{-1}$, LIQ (Limite Inferior de Quantificação). Para o cálculo do ruído da linha de base, foi considerado o intervalo de 1 minuto, antes e após o tempo de retenção do padrão, 17,1 minutos.

Conforme critério de aceitação da ANVISA, (2003), o pico de resposta do LIQ deve ser identificável e reproduzível com precisão de $20 \%$ e exatidão de $80-120 \%$, critério que foi alcançado conforme a Tabela 7. 
Tabela 7 - Dados da determinação do limite inferior de quantificação (LIQ).

\begin{tabular}{c|cccccc}
\hline LIQ $\left(\mu \mathrm{g} \mathrm{mL} \mathbf{~ m}^{-1}\right)$ & Áreas & $\begin{array}{l}\text { Média das } \\
\text { Áreas }\end{array}$ & $\begin{array}{c}D P \\
(\%)\end{array}$ & $\begin{array}{c}\text { DPR } \\
(\%)^{*}\end{array}$ & $\begin{array}{c}\text { Exatidão } \\
(\%)^{* *}\end{array}$ & $\begin{array}{c}C M D \\
\left(\mu \mathrm{g} \mathrm{mL}^{-1}\right)^{\star * *}\end{array}$ \\
\hline \multirow{4}{*}{0,50} & 11,55 & & & & & \\
& 11,49 & & & & & \\
& 11,51 & 11,522 & 0,04 & 8,0 & 91 & 0,454078 \\
& 11,57 & & & & & \\
\hline
\end{tabular}

${ }^{*}$ Precisão ou DPR: (DP/ CMD) *100

** CMD (Concentração média determinada): (Área média - 1,5888) / 21,849

*** Exatidão: (CMD/ Valor teórico) * 100

\subsection{4 - Exatidão e Precisão Intracorrida}

Conforme o Guia de Validação de Métodos Bioanalíticos da ANVISA (2003), para a determinação da exatidão e precisão é necessário verificar no mínimo três concentrações (baixa, média e alta) contemplando a faixa de variação do procedimento, e para cada concentração devem ser feitas no mínimo cinco determinações. A Tabela 8 apresenta os dados obtidos do teste de precisão e exatidão em que foram utilizadas as concentrações de 1,5; 5,0 e 8,5 $\mu \mathrm{g} \mathrm{mL}^{-1}$ do padrão de microcistina-LR, estas soluções foram preparadas em uma matriz similar a da amostra para que houvesse uma maior correspondência com a mesma. 
Tabela 8 - Exatidão/ Precisão Intracorrida.

\begin{tabular}{|c|c|c|c|c|c|c|}
\hline $\begin{array}{l}\text { Concentração } \\
\left(\mu \mathrm{g} \mathrm{mL}^{-1}\right)\end{array}$ & $\begin{array}{c}\text { Áreas } \\
\text { absolutas }\end{array}$ & $\begin{array}{l}\text { Média } \\
\text { áreas }\end{array}$ & $\begin{array}{l}\text { DP } \\
\text { (\%) }\end{array}$ & $\begin{array}{l}\text { Precisão* } \\
\text { (\%) - DPR }\end{array}$ & $\begin{array}{c}\mathrm{CMD}^{* *} \\
\left(\mu \mathrm{g} \mathrm{mL}^{-1}\right)\end{array}$ & $\begin{array}{c}\text { Exatidão } \\
* \star \star ~(\%)\end{array}$ \\
\hline 1,5 & $\begin{array}{l}34,72 \\
34,95 \\
34,48 \\
34,39 \\
34,60 \\
\end{array}$ & 34,628 & 0,2 & 14,5 & 1,5 & 101 \\
\hline 5,0 & $\begin{array}{l}117,33 \\
117,18 \\
117,24 \\
117,47 \\
117,22\end{array}$ & 117,288 & 0,1 & 2,2 & 5,3 & 106 \\
\hline 8,5 & $\begin{array}{l}180,17 \\
179,31 \\
180,61 \\
179,45 \\
180,17\end{array}$ & 179,941 & 0,5 & 6,7 & 8,2 & 96 \\
\hline
\end{tabular}

* Precisão ou DPR: (DP/ CMD) *100

** CMD (Concentração média determinada): (Área média - 1,5888) / 21,849

*** Exatidão: (CMD/ Valor teórico) * 100

\subsection{5 - Exatidão e Precisão Intercorrida}

Para a determinação da exatidão e da precisão intercorrida, foram preparadas em uma matriz similar à da amostra, três concentrações do padrão de microcistina$\mathrm{LR}, 1,5 ; 5,0$ e $8,5 \mu \mathrm{g} \mathrm{mL}^{-1}$, assim como no teste intracorrida. $\mathrm{O}$ teste de intercorridas foi feito dois dias após o da intracorrida, e as soluções padrão foram feitas por outro analista do grupo, conforme recomendações da ANVISA (2003). A Tabela 9 apresenta os dados obtidos. 
Tabela 9 - Dados da Exatidão/ Precisão Intercorridas.

\begin{tabular}{|c|c|c|c|c|c|c|}
\hline $\begin{array}{c}\text { Concentração } \\
\left(\mu \mathrm{g} \mathrm{m}^{-1}\right)\end{array}$ & $\begin{array}{c}\text { Áreas } \\
\text { absolutas }\end{array}$ & $\begin{array}{c}\text { Média } \\
\text { das áreas }\end{array}$ & $\begin{array}{l}\text { DP } \\
\text { (\%) }\end{array}$ & $\begin{array}{l}\text { Precisão* } \\
\text { (\%) - DPR }\end{array}$ & $\begin{array}{c}\mathrm{CMD}^{* *} \\
\left(\mu \mathrm{g} \mathrm{mL}^{-1}\right)\end{array}$ & $\begin{array}{c}\text { Exatidão } \\
* \star * \\
\end{array}$ \\
\hline 1,5 & $\begin{array}{l}32,93 \\
32,94 \\
33,30 \\
32,90 \\
32,85\end{array}$ & 32,984 & 0,2 & 12,5 & 1,4 & 96 \\
\hline 5,0 & $\begin{array}{l}116,10 \\
116,62 \\
116,56 \\
116,69 \\
116,86 \\
\end{array}$ & 116,566 & 0,3 & 5,4 & 5,3 & 105 \\
\hline 8,5 & $\begin{array}{l}180,50 \\
180,67 \\
180,20 \\
179,66 \\
179,83\end{array}$ & 180,172 & 0,4 & 5,2 & 8,2 & 96 \\
\hline
\end{tabular}

${ }^{*}$ Precisão ou DPR: (DP/ CMD) * 100

** CMD (Concentração média determinada): (Área média - 1,5888) / 21,849

*** Exatidão: (CMD/ Valor teórico) ${ }^{*} 100$

Verifica-se pelos dados das Tabelas 8 e 9, que a precisão variou de 2 à $15 \%$ e a exatidão de 4 à $6 \%$, portanto o método pode ser considerado exato e preciso, conforme critério de aceitação da ANVISA, (2003) para métodos bioanalíticos, o desvio padrão relativo (precisão), e a exatidão não podem exceder 15\%.

\subsection{6 - Robustez}

A robustez do método foi avaliada através da verificação da suscetibilidade às variações nas condições cromatográficas, após pequenas alterações nas proporções das fases móveis, acetonitrila 0,05\% TFA e água ultrapura 0,05\%TFA, na velocidade do fluxo da fase móvel, e na troca da coluna cromatográfica por uma outra com material adsorvente relativamente equivalente, e a estabilidade da solução padrão. 


\subsubsection{1 - Fluxo da fase móvel}

O fluxo da fase móvel foi testado em $0,3 \mathrm{~mL} \min ^{-1}$ a menos e $0,2 \mathrm{~mL} \mathrm{~min}^{-1}$ a

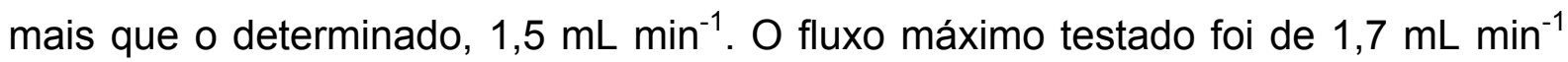
porque fluxos mais altos requerem uma pressão maior do sistema, pressão essa que pode prejudicar o bom funcionamento do mesmo, por se tratar de tubulações milimétricas e muito sensíveis. A pressão com o fluxo de $1,5 \mathrm{~mL} \mathrm{~min}^{-1}$ estabilizou em torno de 144 bar, pressão que pode ser considerada média, e isso se deve à uma maior proporção de fase A (água), que é mais viscosa que a fase B (acetonitrila). Pequenas variações no fluxo da fase móvel podem ocorrer devido à troca de bombas ou entupimento parcial na tubulação do sistema ou da coluna cromatográfica (alteração no material adsorvente da coluna). As Figuras 24 e 25, apresentam os cromatogramas obtidos após a modificação no fluxo, acima $1,7 \mathrm{~mL}$ $\min ^{-1}$ e abaixo $1,2 \mathrm{~mL} \mathrm{~min}^{-1}$ respectivamente.

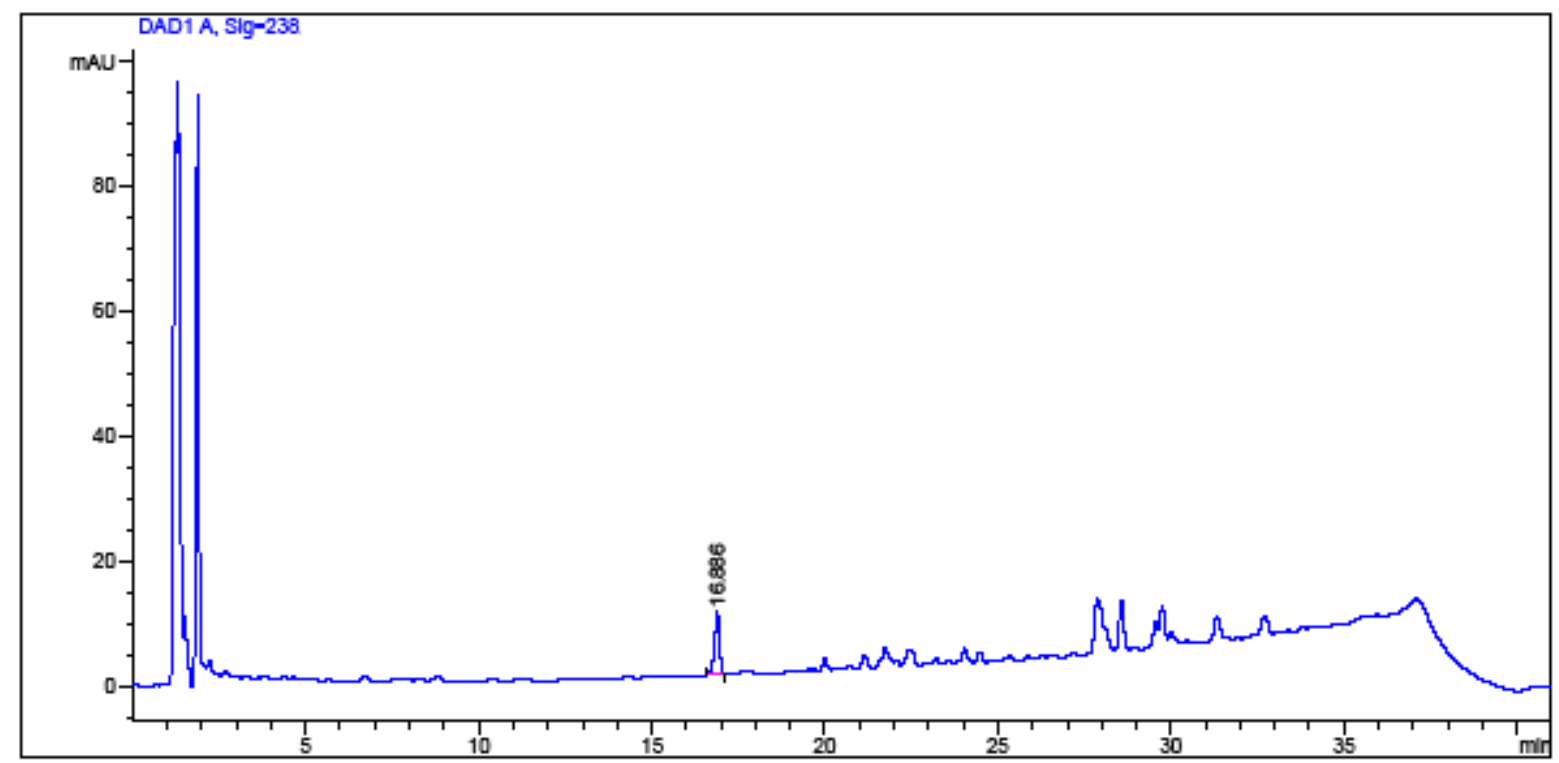

Figura 24: Cromatograma do padrão da microcistina-LR. O tempo de retenção da microcistina-LR

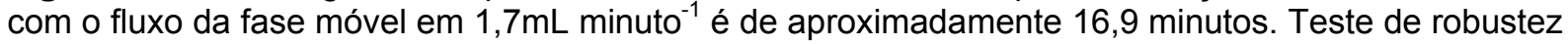
- Fluxo acima. 


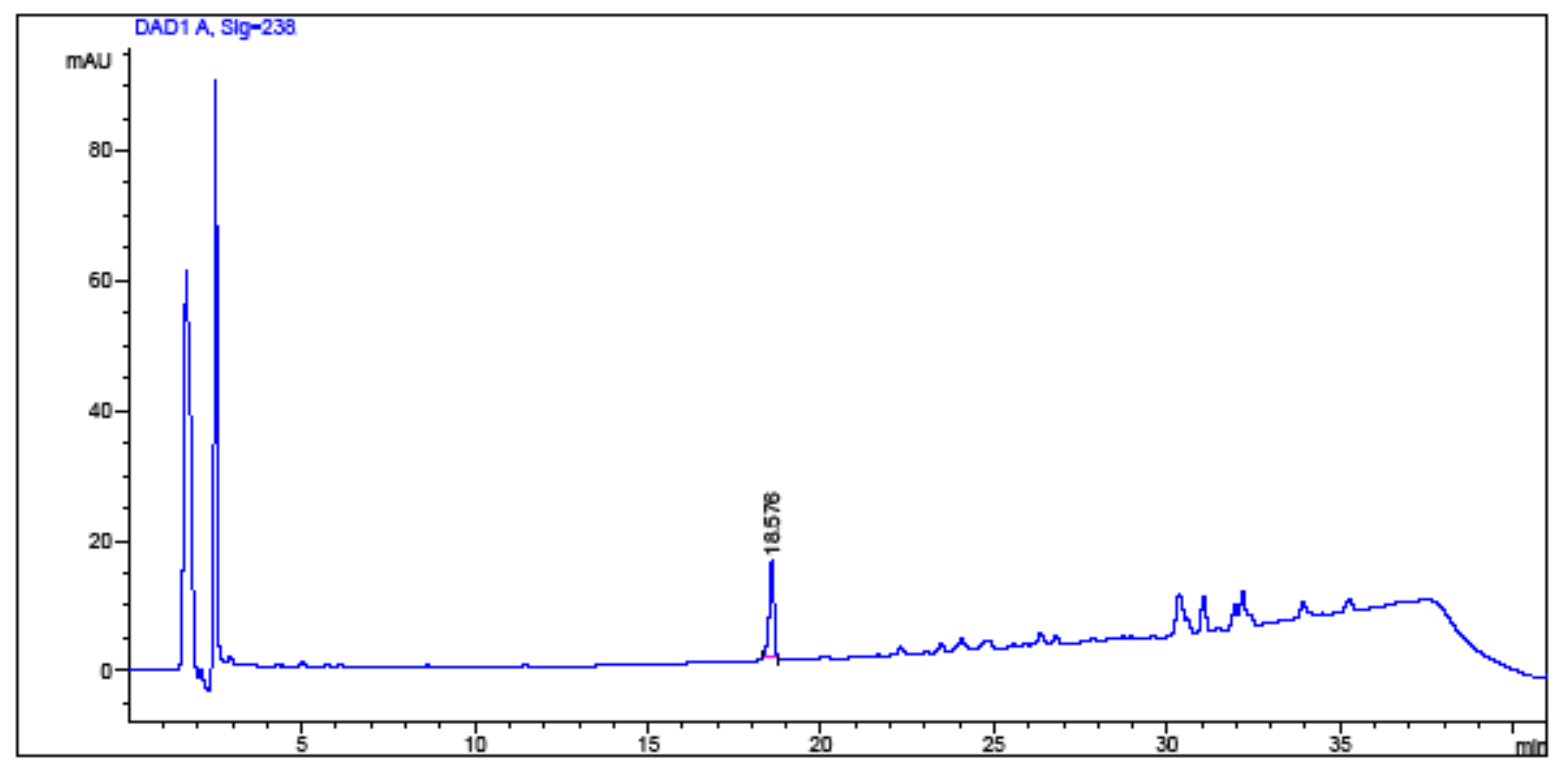

Figura 25: Cromatograma do padrão da microcistina-LR. O tempo de retenção da microcistina-LR com o fluxo da fase móvel em $1,2 \mathrm{~mL} \mathrm{minuto}^{-1}$ é de aproximadamente 18,6 minutos. Teste de robustez- Fluxo abaixo.

\subsubsection{2 - Proporção da fase móvel}

O teste de alteração na proporção da fase móvel pode ser justificado, pois podem ocorrer erros na preparação da fase, devido à utilização de vidrarias descalibradas, ou mesmo por problemas mecânicos nas bombas do cromatógrafo, que são difíceis de serem detectados. As Tabelas 10 e 11 representam os gradientes utilizados na variação da proporção do solvente orgânico em $5 \%$ acima e abaixo da proporção dada por ideal, descrita na Tabela 5 , onde a fase A é água ultrapura 0,05\% TFA, e a fase B é a acetonitrila 0,05\% TFA.

Tabela 10 - Representação do gradiente utilizado na Robustez - Orgânico Acima.

\begin{tabular}{c|cc}
\hline Tempo (minutos) & Fase A(\%) & Fase B(\%) \\
\hline 0 & 65 & 35 \\
10 & 60 & 40 \\
35 & 25 & 75 \\
38 & 65 & 35 \\
41 & 65 & 35 \\
\hline
\end{tabular}


Tabela 11 - Representação do gradiente utilizado na Robustez - Orgânico Abaixo.

\begin{tabular}{c|cc}
\hline Tempo (minutos) & Fase A(\%) & Fase B(\%) \\
\hline 0 & 75 & 25 \\
10 & 60 & 30 \\
35 & 35 & 65 \\
38 & 75 & 25 \\
41 & 75 & 25 \\
\hline
\end{tabular}

As Figuras 26 e 27 apresentam os cromatogramas obtidos após as variações na proporção das fases $A$ e B.

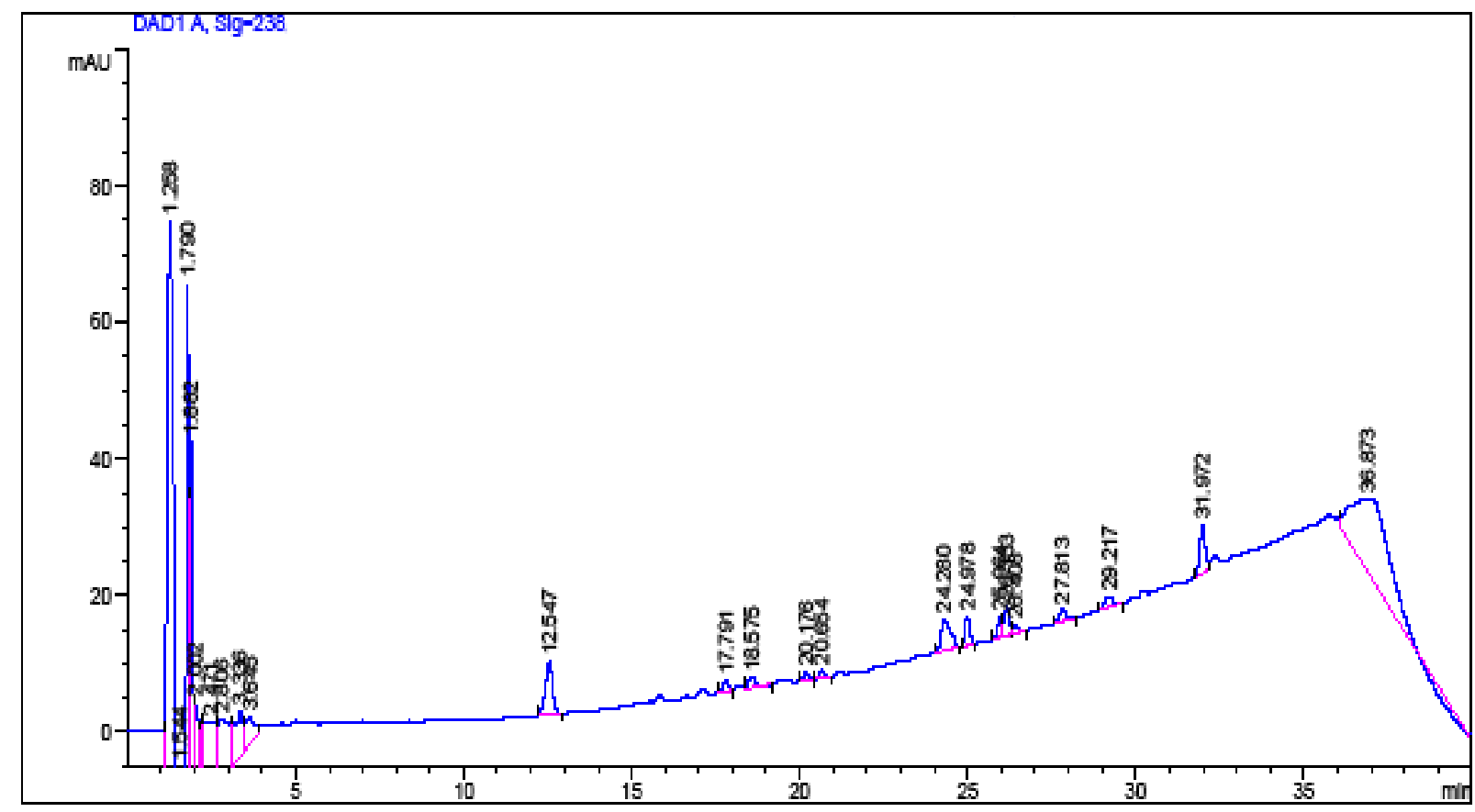

Figura 26: Cromatograma do padrão da microcistina-LR. O tempo de retenção da microcistina-LR quando a proporção de solvente orgânico é aumentada em $5 \%$ é de 12,5 minutos. Proporções do gradiente vide Tabela 10. Teste de robustez - Orgânico Acima. 


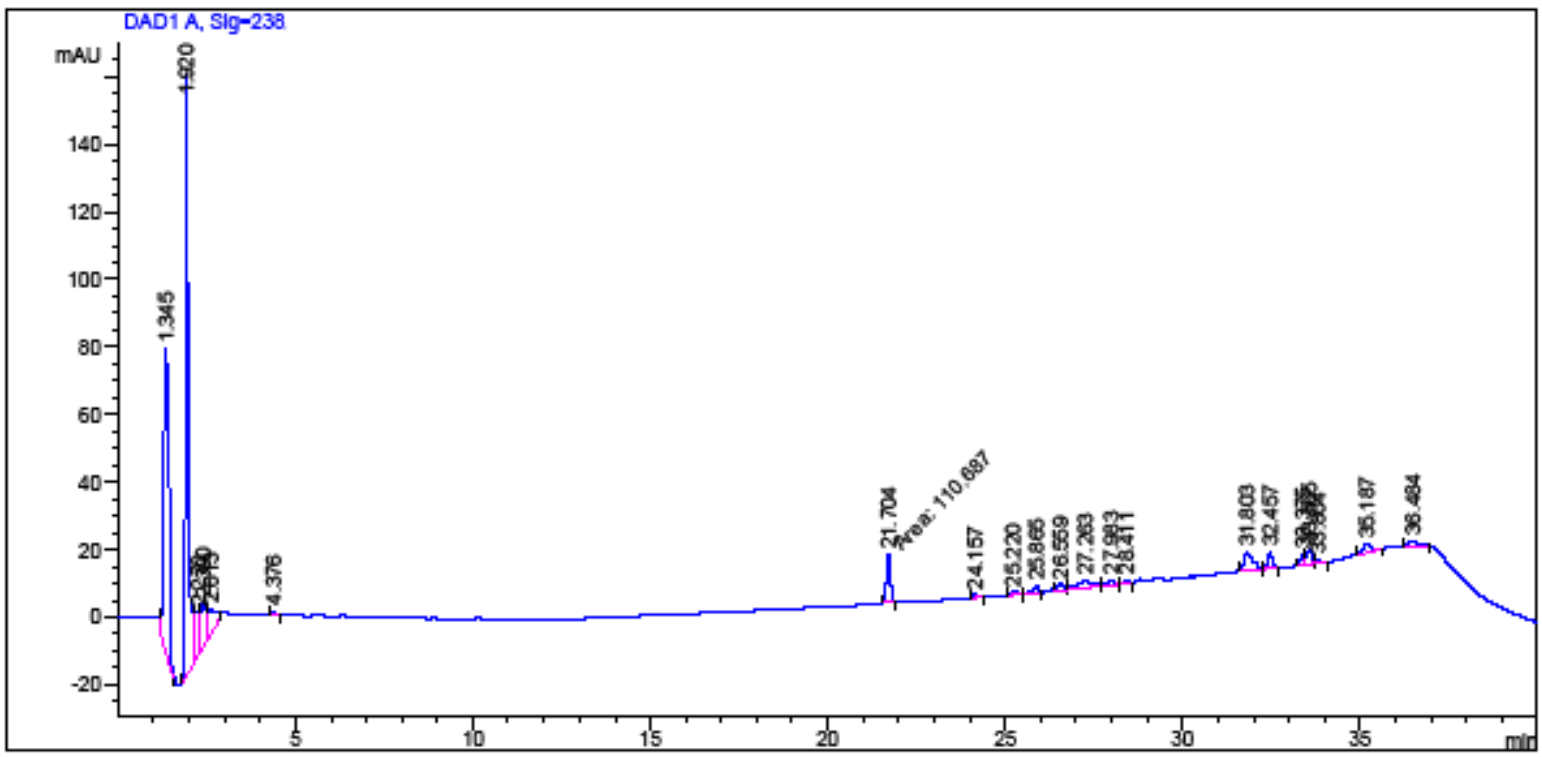

Figura 27: Cromatograma do padrão da microcistina-LR. O tempo de retenção da microcistina-LR quando a proporção de solvente orgânico é diminuida em $5 \%$ é de 21,7 minutos. Proporções do gradiente vide Tabela 11. Teste de robustez - Orgânico Abaixo.

\subsubsection{3 - Troca de Coluna}

A coluna da marca Zorbax SB-C18, utilizada em todos os testes da validação do método, apresentou um número superior de pratos teóricos, em torno de 80000 , em relação à coluna da marca Nucleosil, que apresentou um número próximo de 31000. A simetria do pico da microcistina-LR obtida com a coluna Zorbax ficou em 1,2, (entre 0,8 e 1,5), conforme a Figura 15, e da Nucleosil C18, a simetria ficou igual ao limite máximo considerado, 1,5 , isso pode ter acontecido devido ao tempo de uso da coluna, que é maior do que o da coluna Zorbax. As características das colunas também se modificam conforme o solvente utilizado e a forma de utilização (limpeza, condicionamento, estocagem, etc).

O cromatograma correspondente ao teste de troca de coluna está apresentado como Figura 16, no item 4.2, "Condições cromatográficas estudadas". 


\subsubsection{4 - Resultados da Robustez}

A Tabela 12 apresenta os dados obtidos a partir das variações feitas no método. Os valores de tempo de retenção (TR), altura, área A (área dos picos das amostras), simetria e recuperação, representam a média dos resultados das amostras feitas em duplicata, e a área do padrão (PD) representa a média de cinco determinações do padrão, injetadas nas mesmas condições dos testes, por exemplo, no teste de alteração do fluxo. As injeções das amostras foram feitas intercaladas à injeções dos padrões, e para que o teste fosse considerado válido, foi determinado um limite máximo para o desvio das áreas dos padrões, de $2 \%$.

Tabela 12 - Resultados da avaliação da robustez do método validado.

\begin{tabular}{|c|c|c|c|c|c|c|c|}
\hline Teste & $\begin{array}{c}\text { Fluxo } \\
(\mathbf{m L} / \mathbf{m i n})\end{array}$ & TR & Altura & Área A & $\begin{array}{c}\text { Área } \\
\text { PD }\end{array}$ & Simetria & $\begin{array}{c}\text { Recuperação } \\
(\%)\end{array}$ \\
\hline A & 1,2 & 18,6 & 13,1 & 132,96 & 131,93 & 1,3 & 101 \\
\hline B & 1,7 & 16,9 & 10,0 & 106,66 & 98,41 & 1,2 & 108 \\
\hline C & 1,5 & 21,7 & 12,7 & 110,67 & 118,48 & 1,0 & 106 \\
\hline D & 1,5 & 12,5 & 8,3 & 115,56 & 104,40 & 1,2 & 98 \\
\hline E & 1,5 & 16,5 & 6,3 & 88,28 & 88,37 & 1,5 & 100 \\
\hline F & 1,5 & 17,3 & 11,0 & 107,55 & 105,37 & 1,2 & 102 \\
\hline
\end{tabular}

Legenda dos testes: A: Fluxo Abaixo: 1,2mL $\mathrm{min}^{-1}$, B: Fluxo Acima: 1,7mL $\mathrm{min}^{-1}$, C: Orgânico Abaixo: vide Tabela 11, D: Orgânico Acima: vide Tabela 10, E: Troca de Coluna: Nucleosil C18 e F: Sem Variação

A variação do tempo de retenção da microcistina-LR após as alterações nas condições cromatográficas consideradas ideais, foi de aproximadamente 4 minutos, considerando que o pico da mesma, nas condições sem variação, eluiu em 17,3 minutos. Essa variação pode ser considerada alta em termos analíticos, porém foi observado que não há influência de picos interferentes próximos ao tempo de 
retenção do analito, e as porcentagens de recuperação obtidas de 98 à 108\% são consideradas boas e dentro da faixa de $15 \%$.

\subsection{7 - Estabilidade da solução padrão de microcistina- LR em metanol acidificado}

A estabilidade da solução padrão foi testada em 24 e 48 horas após o preparo, e em temperatura ambiente, aproximadamente $22^{\circ} \mathrm{C}$, o resultado foi obtido por comparação de área com padrões recém preparados, na mesma concentração dos padrões de teste. A concentração do padrão que teve sua estabilidade testada em 24 horas, foi a de $4 \mu \mathrm{g} \mathrm{mL}^{-1}$, e a de 48 horas, a de $5,0 \mu \mathrm{g} \mathrm{mL}^{-1}$. Foram testadas duas concentrações diferentes, de soluções-padrão, para uma maior confiabilidade no resultado. A Tabela 13 apresenta os valores do teste de estabilidade da solução padrão de microcistina- LR em metanol acidificado, $\mathrm{pH} \sim 2$.

Tabela 13 - Estabilidade das soluções padrão, 24 e 48 horas em temperatura ambiente.

\begin{tabular}{|c|c|c|c|}
\hline $\begin{array}{c}\text { Solução } \\
\text { Padrão }\end{array}$ & $\begin{array}{c}\text { Área Padrão } \\
\text { Recém- preparado }\end{array}$ & $\begin{array}{c}\text { Área Padrão } \\
\text { Estabilidade }\end{array}$ & $\begin{array}{c}\text { Recuperação } \\
(\%)\end{array}$ \\
\hline $24 \mathrm{~h}$ & 99,5 & 94,7 & 95 \\
$48 \mathrm{~h}$ & 105,4 & 112,5 & 107 \\
\hline
\end{tabular}

Conforme critério de aceitação da Resolução da ANVISA, a solução padrão pode ser considerada estável, pois o desvio em comparação aos padrões recém preparados não passa de 15\%. É importante o estudo da estabilidade da solução padrão, visto que o tempo de corrida da amostra é longo, 41 minutos, e se faz necessário fazer uma nova curva analítica com padrões nas concentrações 
determinadas na linearidade, à cada determinação. E considerando o tempo total da análise, pode-se considerar em torno de um dia.

\subsection{8 - Recuperação}

Este teste foi realizado conforme sugestão da ANVISA, para métodos bioanalíticos, baseado na comparação dos resultados analíticos de amostras extraídas a partir de três concentrações (baixa, média e alta), contemplando a faixa de linearidade do método, com os resultados obtidos com soluções padrão não extraídas, que representam $100 \%$ de recuperação.

A Tabela 14 apresenta a porcentagem de recuperação obtida nas determinações em que foram comparadas respostas obtidas de padrões, preparados com o solvente metanol acidificado com TFA $(\mathrm{pH} 2)$, nas concentrações de 1,5; 5,0 e $8,5 \mu \mathrm{g} \mathrm{mL}{ }^{-1}$, consideradas baixa, média e alta (conforme a faixa de estudo), com a de amostras preparadas dopando uma matriz com padrão de microcistina-LR, (essa matriz foi analisada previamente e comprovada a ausência da microcistina-LR), de modo que a concentração final fosse igual às dos padrões (com solvente). Essas amostras foram extraídas conforme descrito no item 3.2, "Preparação das amostras".

Tabela 14 - Resultados dos testes de recuperação.

\begin{tabular}{c|ccc}
\hline $\begin{array}{c}\text { Concentração } \\
\left.\text { (ug } \text { L L }^{-1}\right)\end{array}$ & $\begin{array}{c}\text { Áreas } \\
\text { Padrões* }\end{array}$ & $\begin{array}{c}\text { Áreas } \\
\text { Amostras* }\end{array}$ & \% Recuperação \\
\hline 1,5 & 31,4897 & 28,3628 & $90 \pm 4,3$ \\
5,0 & 115,9332 & 104,2467 & $90 \pm 1,6$ \\
8,5 & 201,3948 & 194,3777 & $97 \pm 2,0$ \\
\hline
\end{tabular}

* Média de três determinações.

A porcentagem de recuperação de $97 \%$, para a concentração de $8,5 \mu \mathrm{g} \mathrm{mL}^{-1}$, é considerada boa, por estar próxima à porcentagem ideal, de $100 \%$. Porém para as 
concentrações mais baixas, que são mais próximas às encontradas nas amostras de floração de cianobactérias, houve uma distância significativa do valor esperado. Para poder compensar esse tipo de variação, os testes de linearidade, precisão, exatidão e robustez do método, foram feitos utilizando padrões extraídos da mesma maneira que as amostras.

\subsection{9 - Curva Analítica}

As soluções padrão de microcistina-LR extraídas analisadas em ordem crescente de concentração $\left(0,5 \mu \mathrm{g} \mathrm{mL}^{-1}(\mathrm{LIQ}), 1,0 ; 2,0 ; 4,0 ; 8,0\right.$ e $\left.10,0 \mu \mathrm{g} \mathrm{mL}^{-1}\right)$ e nas especificações descritas no item 4.2 - Condições cromatográficas estudadas, Tabelas 2 e 3. Considerando estas concentrações juntamente com as suas respectivas respostas dos picos cromatográficos referentes à microcistina-LR, foi possível confeccionar a curva analítica, ou, curva de calibração (Figura 28). A Tabela 15 apresenta os dados utilizados na determinação da curva analítica. 
Tabela 15 - Dados da curva analítica obtida com a resposta das áreas dos picos cromatográficos referentes ao padrão de microcistina-LR.

\begin{tabular}{|c|c|c|c|c|c|c|}
\hline 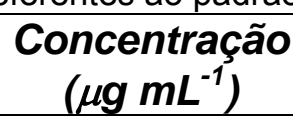 & $\begin{array}{c}\text { Área } \\
\text { Absoluta }\end{array}$ & $\begin{array}{c}\text { Área } \\
\text { média }\end{array}$ & $\begin{array}{l}D P \\
(\%)\end{array}$ & $\begin{array}{c}\text { Precisão } \\
(\%)^{*}\end{array}$ & $\begin{array}{c}C M D^{* *} \\
\left(\mu g L^{-1}\right)\end{array}$ & $\begin{array}{c}\text { Exatidão } \\
(\%)^{\star * \star}\end{array}$ \\
\hline 0,5 & $\begin{array}{l}11,5488 \\
11,2181 \\
11,0905\end{array}$ & 11,2858 & 0,2 & 2,1 & 0,4 & 89 \\
\hline 1,0 & $\begin{array}{l}21,1433 \\
22,0789 \\
21,3684\end{array}$ & 21,5302 & 0,5 & 2,3 & 0,9 & 91 \\
\hline 2,0 & $\begin{array}{l}45,2871 \\
45,6936 \\
45,1288\end{array}$ & 45,3698 & 0,3 & 0,6 & 2,0 & 100 \\
\hline 4,0 & $\begin{array}{l}88,8494 \\
91,0310 \\
90,9808 \\
\end{array}$ & 90,2871 & 1,2 & 1,4 & 4,1 & 102 \\
\hline 8,0 & $\begin{array}{l}184,7565 \\
187,3180 \\
187,5969 \\
\end{array}$ & 186,5571 & 1,6 & 0,8 & 8,5 & 106 \\
\hline 10,0 & $\begin{array}{l}211,0641 \\
212,2541 \\
211,6402\end{array}$ & 211,6528 & 0,6 & 0,3 & 9,6 & 96 \\
\hline
\end{tabular}

* Precisão: (DP/ Área média) *100

** CMD (Concentração média determinada): (Área média - 1,5888) / 21,849

*** Exatidão: (CMD/ Valor teórico) * 100

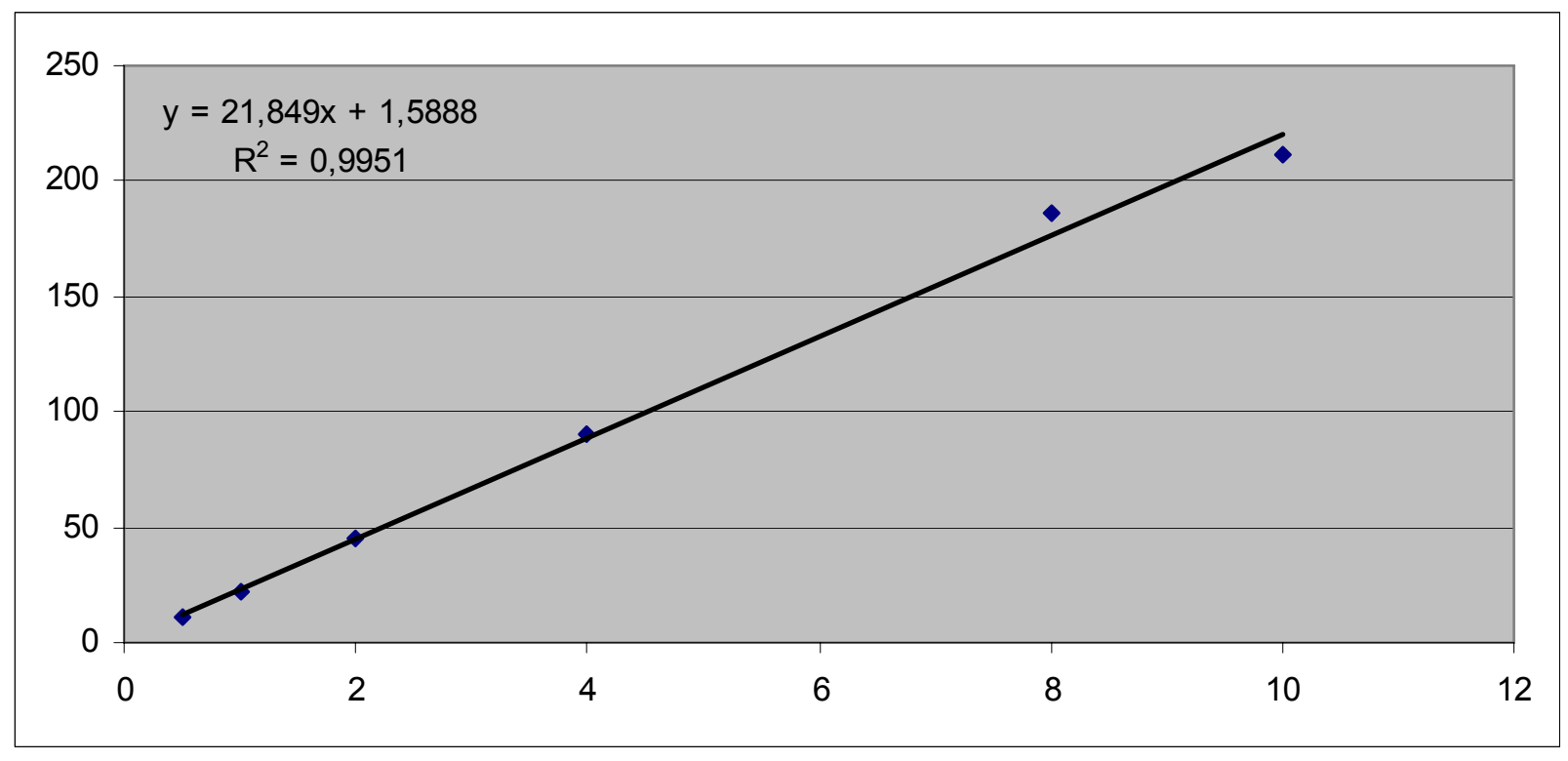

Figura 28: Curva analítica, respostas das áreas dos picos das soluções-padrão da microcistina-LR versus concentração (Método de Superposição de Matriz). 
A curva analítica revela uma boa linearidade, com coeficiente de correlação, $r$, muito próximo da unidade, 0,997. O coeficiente considerado como critério de aceitação nesse estudo foi igual ou superior a 0,98 . A equação da reta obtida, y = $1,5888+21,849 x$, pode ser utilizada para a quantificação da microcistina-LR nas amostras de florações de cianobactérias, que apresentarem em seus cromatogramas, picos característicos da microcistina-LR. Essa equação é válida para as amostras que foram analisadas por meio da aplicação do gradiente, descrito em condições cromatográficas utilizadas na validação do método. O parâmetro y representa a área relacionada ao pico de mesmo tempo de retenção que o do padrão da microcistina-LR, e o parâmetro x fornece a concentração correspondente, conforme os dados utilizados na confecção da curva analítica.

A linearidade também pode ser determinada pela altura dos picos. A Tabela 16 apresenta os dados encontrados utilizando a altura dos picos do padrão da microcistina-LR. 
Tabela 16 - Dados da curva analítica obtida com a resposta das alturas dos picos cromatográficos referentes ao padrão da microcistina-LR.

\begin{tabular}{|c|c|c|c|c|c|c|}
\hline $\begin{array}{c}\text { Concentração } \\
\left(\mu \mathrm{g} L^{-1}\right)\end{array}$ & $\begin{array}{c}\text { Altura } \\
\text { Absoluta }\end{array}$ & $\begin{array}{l}\text { Altura } \\
\text { média }\end{array}$ & $\begin{array}{l}D P \\
(\%)\end{array}$ & $\begin{array}{c}\text { Precisão } \\
(\%)^{*}\end{array}$ & $\begin{array}{c}C M D^{* *} \\
\left(\mu g L^{-1}\right)\end{array}$ & $\begin{array}{c}\text { Exatidão } \\
(\%)^{* * *}\end{array}$ \\
\hline 0,5 & $\begin{array}{l}1,2441 \\
1,2130 \\
1,1788 \\
\end{array}$ & 1,2120 & 0,03 & 2,7 & 0,4 & 88 \\
\hline 1,0 & $\begin{array}{l}2,2664 \\
2,3114 \\
2,2898 \\
\end{array}$ & 2,2892 & 0,02 & 1,0 & 0,9 & 92 \\
\hline 2,0 & $\begin{array}{l}4,7380 \\
4,7597 \\
4,6555 \\
\end{array}$ & 4,7178 & 0,05 & 1,2 & 2,0 & 101 \\
\hline 4,0 & $\begin{array}{l}9,0257 \\
9,4180 \\
9,4045\end{array}$ & 9,2827 & 0,22 & 2,4 & 4,1 & 102 \\
\hline 8,0 & $\begin{array}{l}18,4289 \\
18,8707 \\
18,9821 \\
\end{array}$ & 18,7605 & 0,29 & 1,6 & 8,3 & 104 \\
\hline 10,0 & $\begin{array}{l}21,5979 \\
21,9114 \\
21,7877\end{array}$ & 21,7657 & 0,16 & 0,7 & 9,7 & 97 \\
\hline
\end{tabular}

* Precisão: (DP/ Área média) *100

** CMD (Concentração média determinada): (Área média - 1,5888) / 21,849

*** Exatidão: (CMD/ Valor teórico) * 100

A Figura 29 apresenta o gráfico da altura dos picos do padrão da microcistina-

$L R$ versus a concentração dos mesmos.

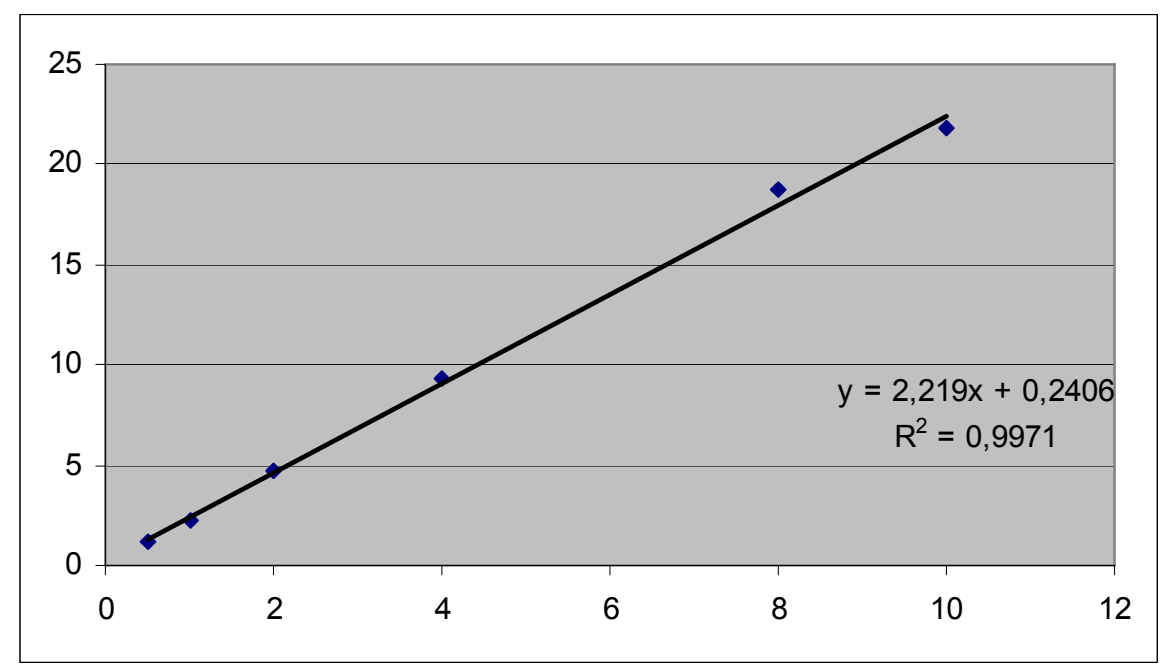

Figura 29: Curva analítica, respostas das alturas dos picos das soluções-padrão da microcistina-LR versus concentração (Método de Superposição de Matriz). 
A curva obtida com os dados da altura do pico também revelou uma boa linearidade, com coeficiente de correlação $(r)$, muito próximo da unidade, 0,9985. Quanto mais próximo de 1,0, menor a dispersão do conjunto de pontos experimentais e menor a incerteza dos coeficientes de regressão estimados. A equação da reta obtida, $y=0,2406+2,219 x$, pode ser utilizada para a quantificação das amostras que apresentarem nos seus cromatogramas, picos característicos da microcistina-LR.

\section{5 - Aplicação do método validado}

Dentre os pesque-pagues e pisciculturas visitados, foram coletadas amostras daqueles que apresentavam características assim como a do tanque do estabelecimento A, representado na Figura 30.

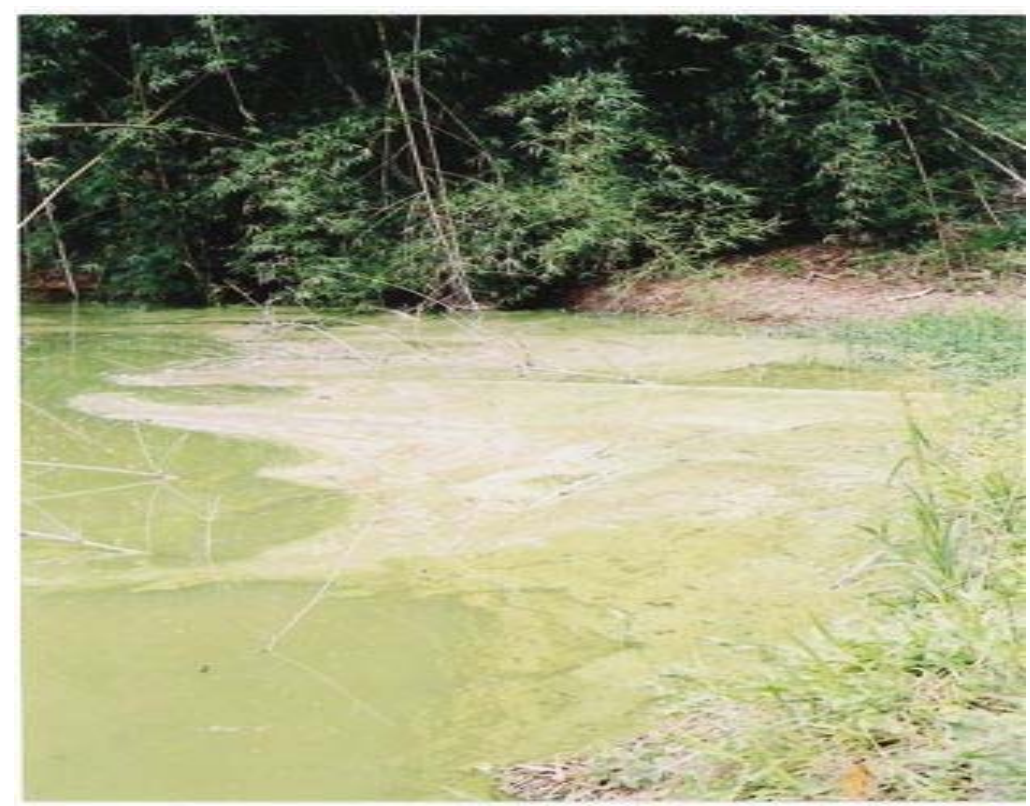

Figura 30: Fotografia do tanque do estabelecimento A com a presença de florações de cianobactérias. Fotografia tirada em setembro de 2007, por Eny Maria Vieira. 
Os extratos de florações de cianobactérias coletadas em diversas épocas do ano, que estavam liofilizadas e armazenadas em temperatura de aproximadamente $20^{\circ} \mathrm{C}$, foram analisadas conforme as condições cromatográficas validadas: gradiente descrito na Tabela 2, coluna Nucleosil C18, com tamanho de partícula de $5 \mu \mathrm{m}, 250$ $\mathrm{mm}$ de comprimento e 4,6 mm de diâmetro interno, comprimento de onda de $238 \mathrm{~nm}$ e fluxo de $1,5 \mathrm{~mL} \min ^{-1}$. $E$ e os cromatogramas estão descritos nas Figuras apresentadas a seguir.

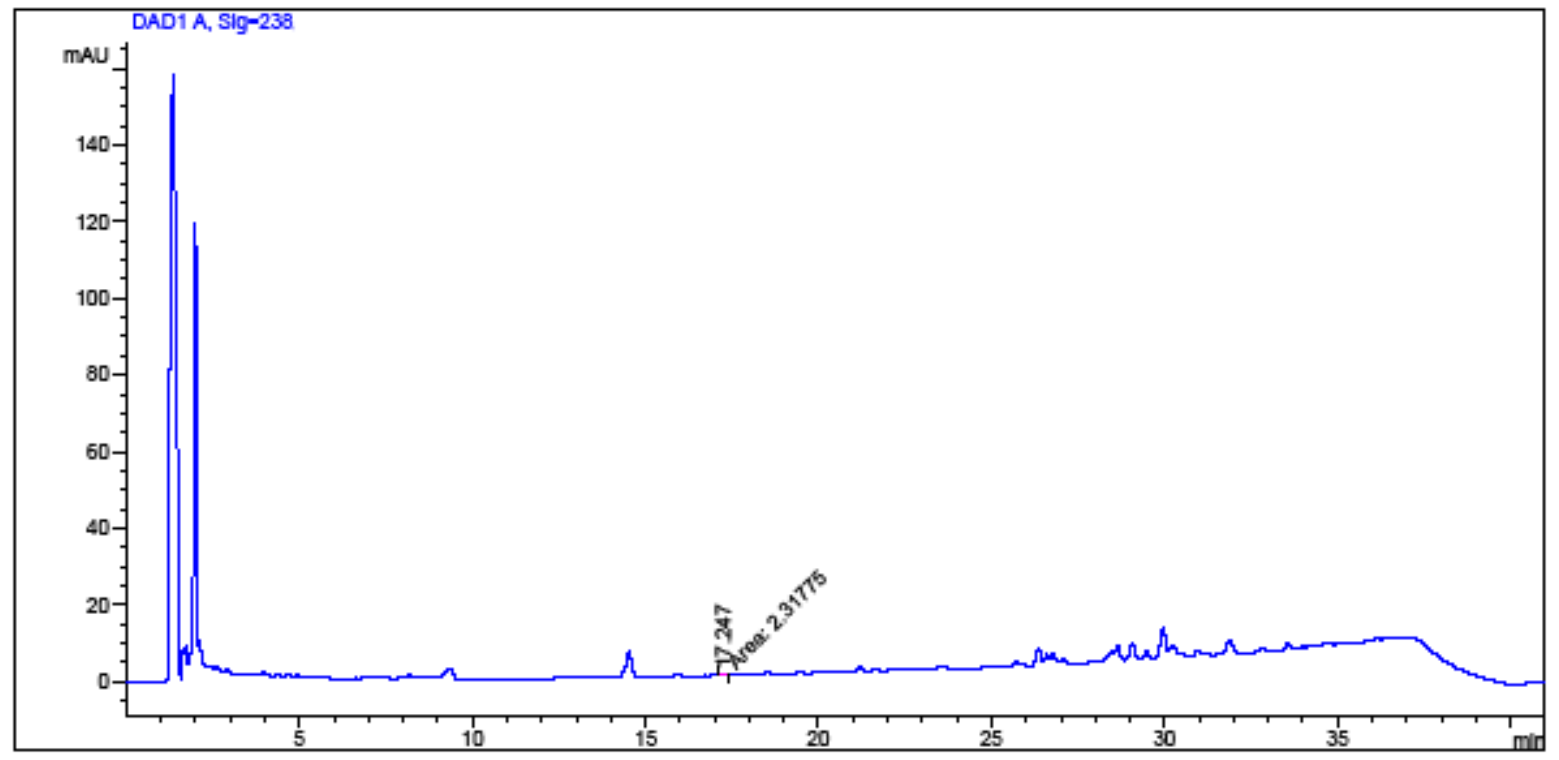

Figura 31: Cromatograma do extrato de floração de cianobactéria do estabelecimento $A$, coletado em outubro de 2006. Obtido conforme o gradiente descrito na Tabela 2, coluna Nucleosil C18, com tamanho de partícula de $5 \mathrm{um}, 250 \mathrm{~mm}$ de comprimento e 4,6 $\mathrm{mm}$ de diâmetro interno, comprimento

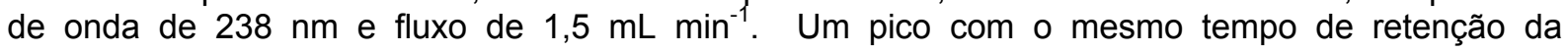
microcistina-LR foi encontrado. 


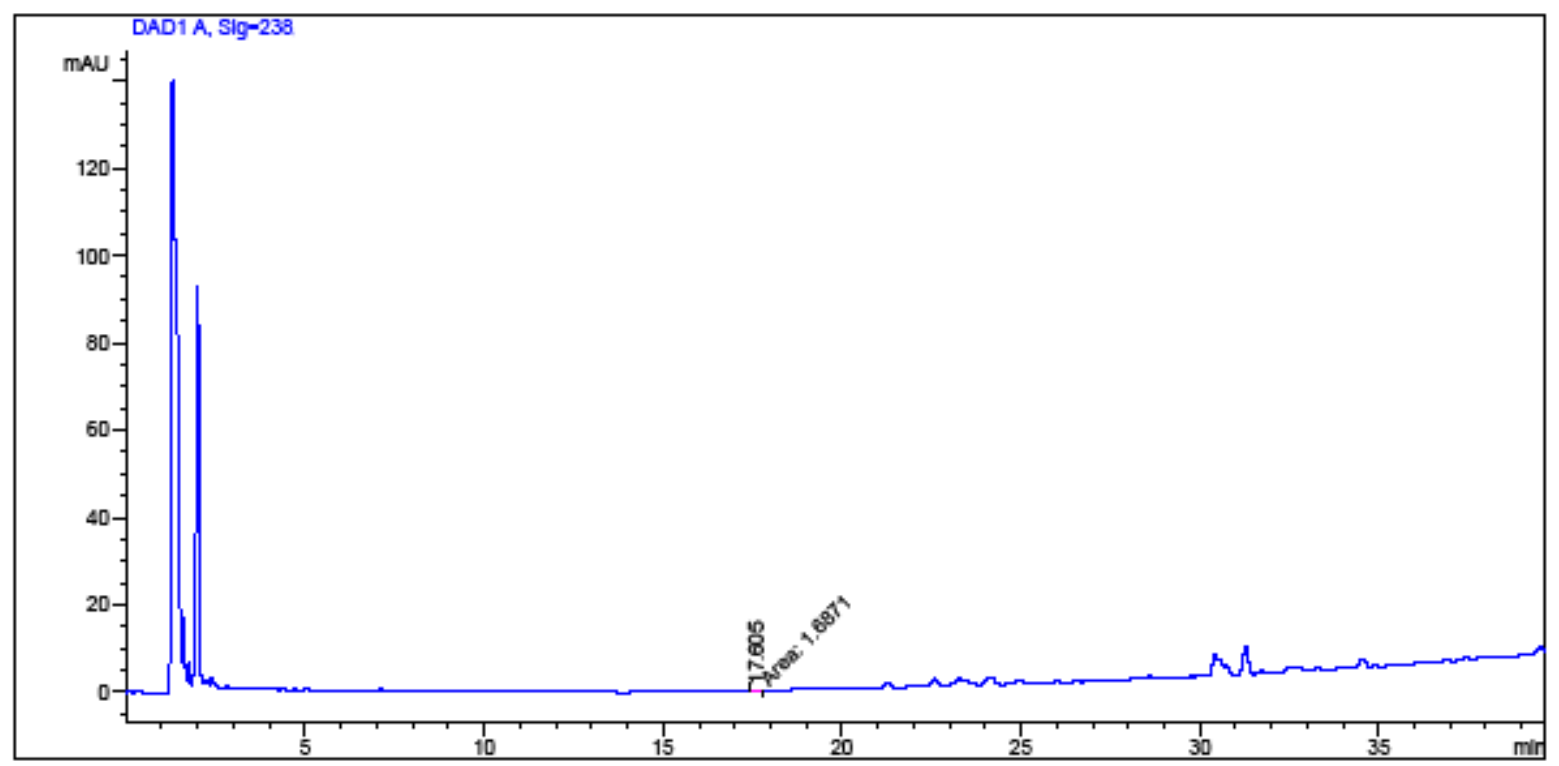

Figura 32: Cromatograma do extrato de floração de cianobactéria do estabelecimento $B$, coletado em outubro de 2006. Obtido conforme o gradiente descrito na Tabela 2, coluna Nucleosil C18, com tamanho de partícula de $5 \mathrm{um}, 250 \mathrm{~mm}$ de comprimento e 4,6 mm de diâmetro interno, comprimento de onda de $238 \mathrm{~nm}$ e fluxo de $1,5 \mathrm{~mL} \mathrm{~min}^{-1}$. Um pico com o mesmo tempo de retenção da microcistina-LR foi encontrado.

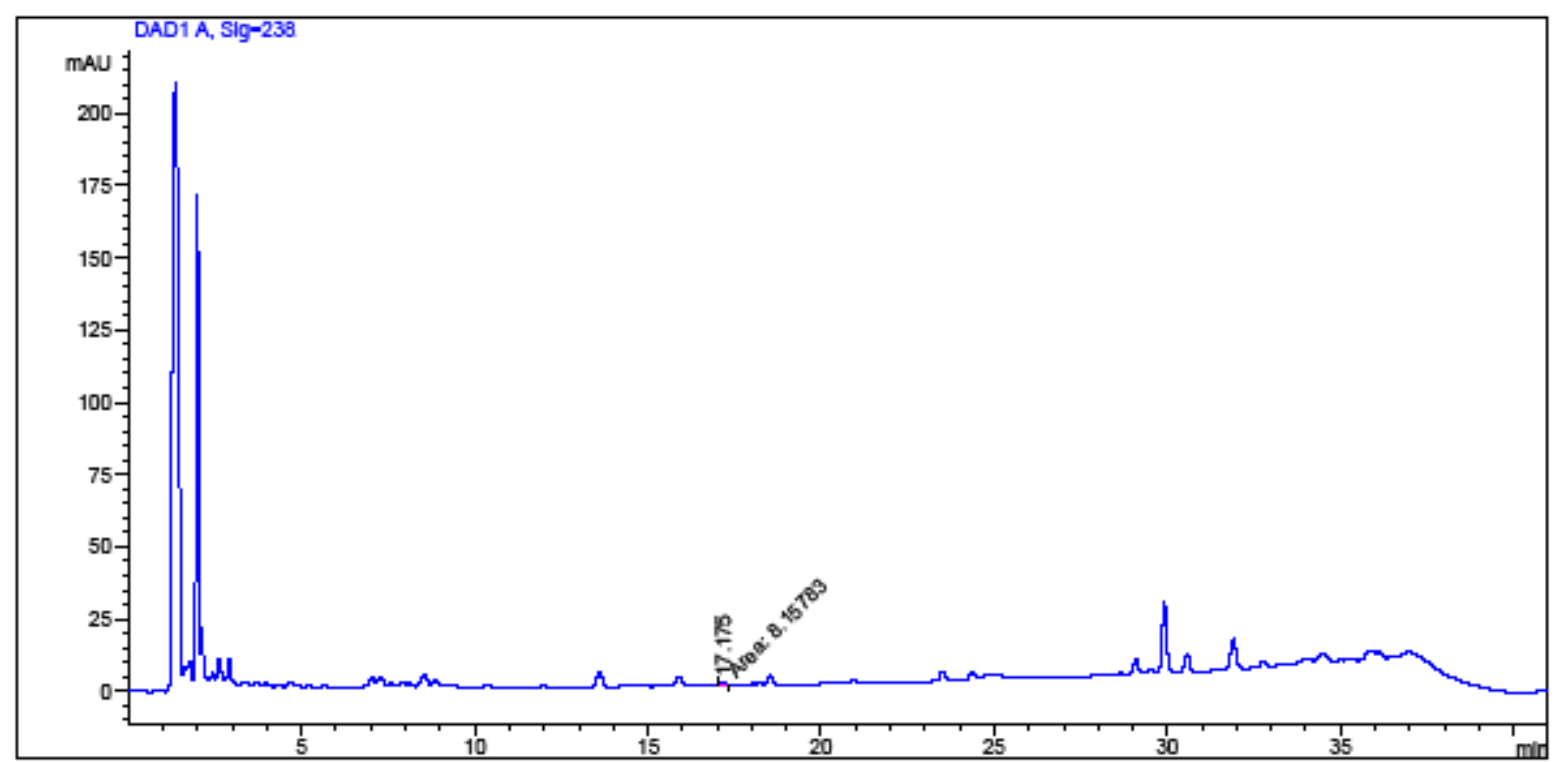

Figura 33: Cromatograma do extrato de floração de cianobactéria do estabelecimento $D$, coletado em maio de 2007. Obtido conforme o gradiente descrito na Tabela 2, coluna Nucleosil C18, com tamanho de partícula de $5 \mathrm{um}, 250 \mathrm{~mm}$ de comprimento e 4,6 mm de diâmetro interno, comprimento de onda de $238 \mathrm{~nm}$ e fluxo de $1,5 \mathrm{~mL} \mathrm{~min}^{-1}$. Um pico com o mesmo tempo de retenção da microcistina-LR foi encontrado. 


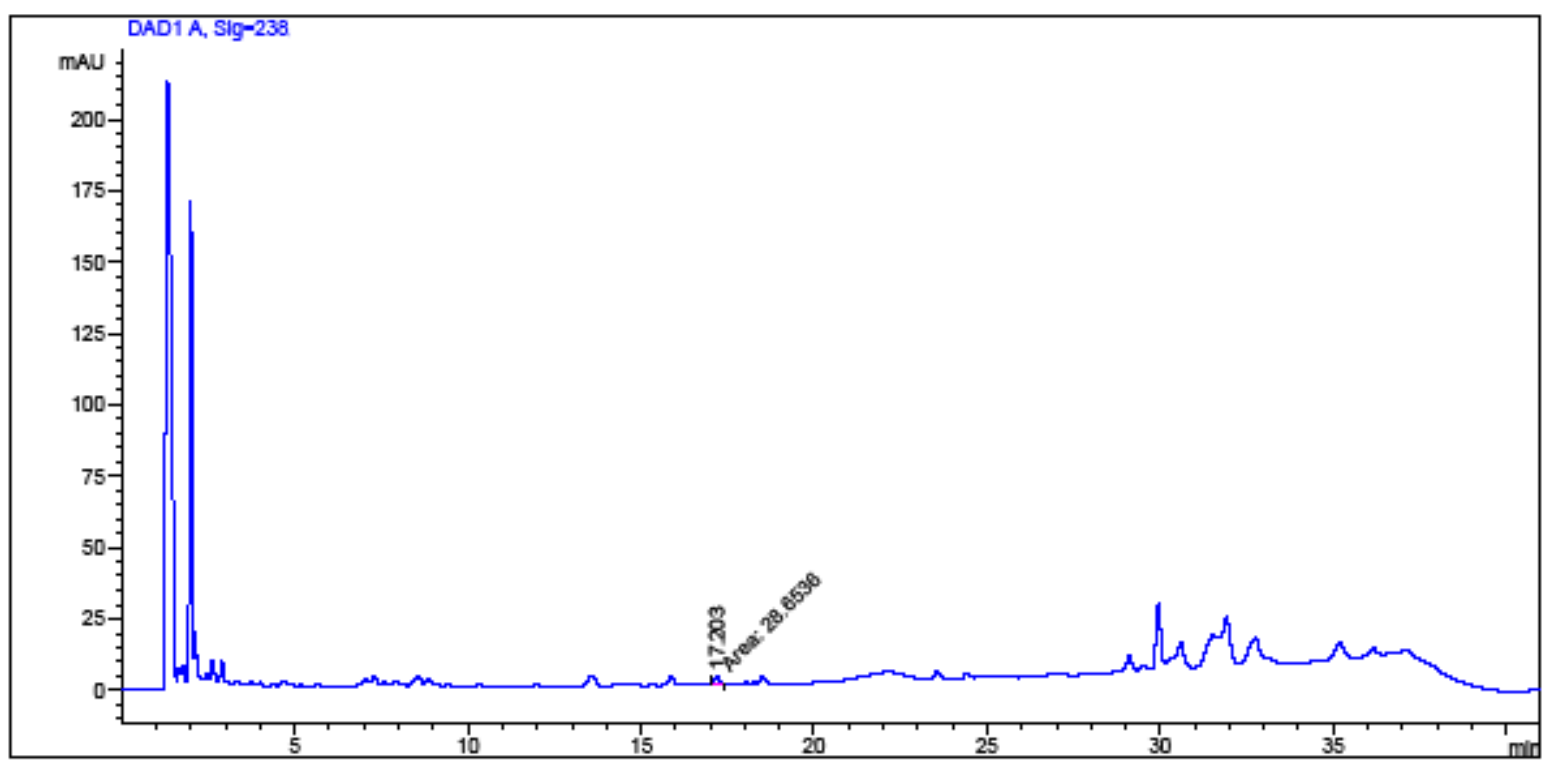

Figura 34: Cromatograma do extrato de floração de cianobactéria do estabelecimento $\mathrm{C}$, coletado em maio de 2007. Obtido conforme o gradiente descrito na Tabela 2, coluna Nucleosil C18, com tamanho de partícula de $5 \mathrm{um}, 250 \mathrm{~mm}$ de comprimento e 4,6 $\mathrm{mm}$ de diâmetro interno, comprimento de onda de $238 \mathrm{~nm}$ e fluxo de $1,5 \mathrm{~mL} \mathrm{~min}^{-1}$. Um pico com o mesmo tempo de retenção da microcistina-LR foi encontrado.

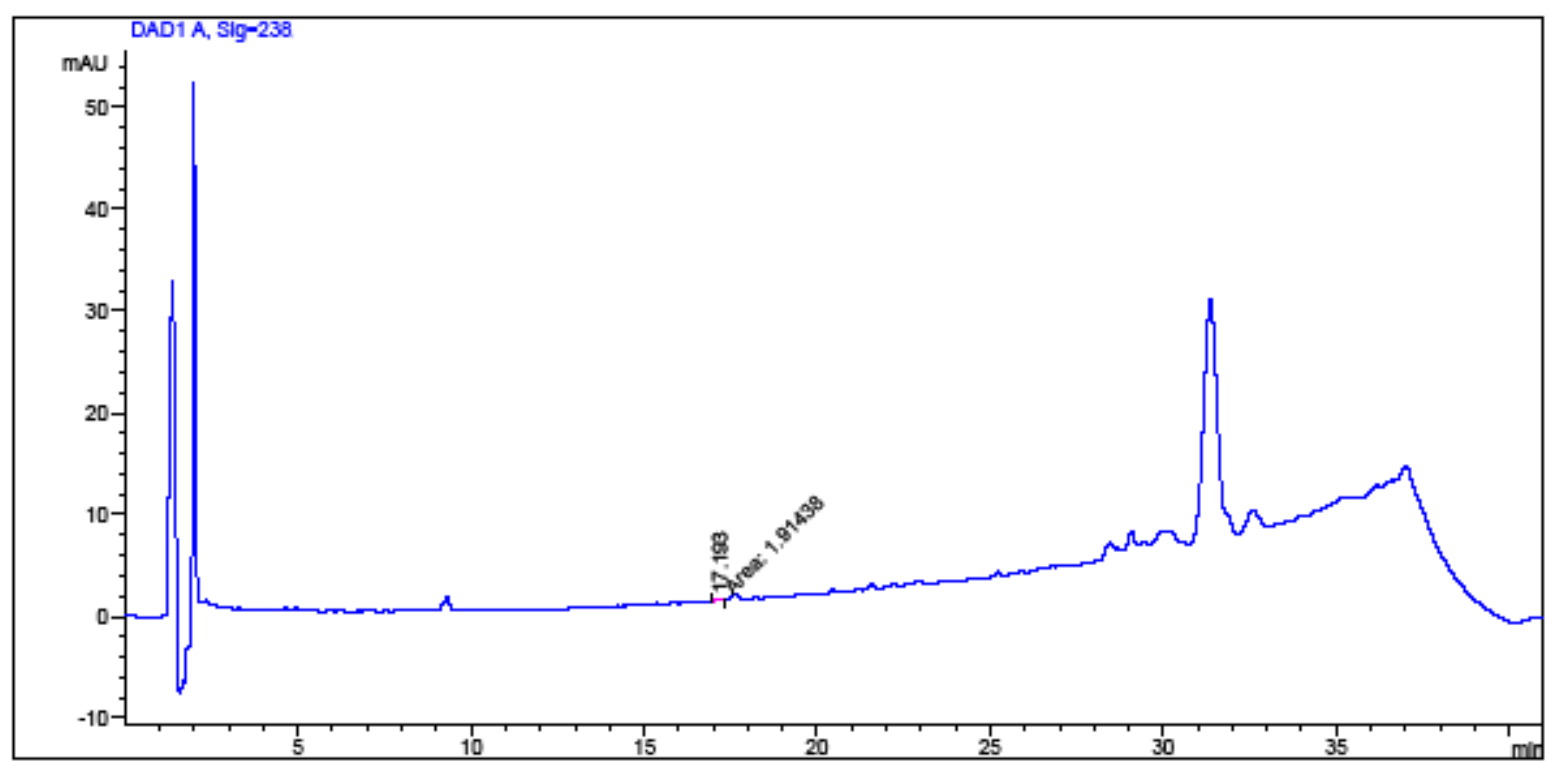

Figura 35: Cromatograma do extrato de floração de cianobactéria do estabelecimento $A$, coletado em setembro de 2007. Obtido conforme o gradiente descrito na Tabela 2, coluna Nucleosil C18, com tamanho de partícula de $5 \mathrm{um}, 250 \mathrm{~mm}$ de comprimento e $4,6 \mathrm{~mm}$ de diâmetro interno, comprimento de onda de $238 \mathrm{~nm}$ e fluxo de $1,5 \mathrm{~mL} \mathrm{~min}^{-1}$. Um pico com o mesmo tempo de retenção da microcistina-LR foi encontrado. 


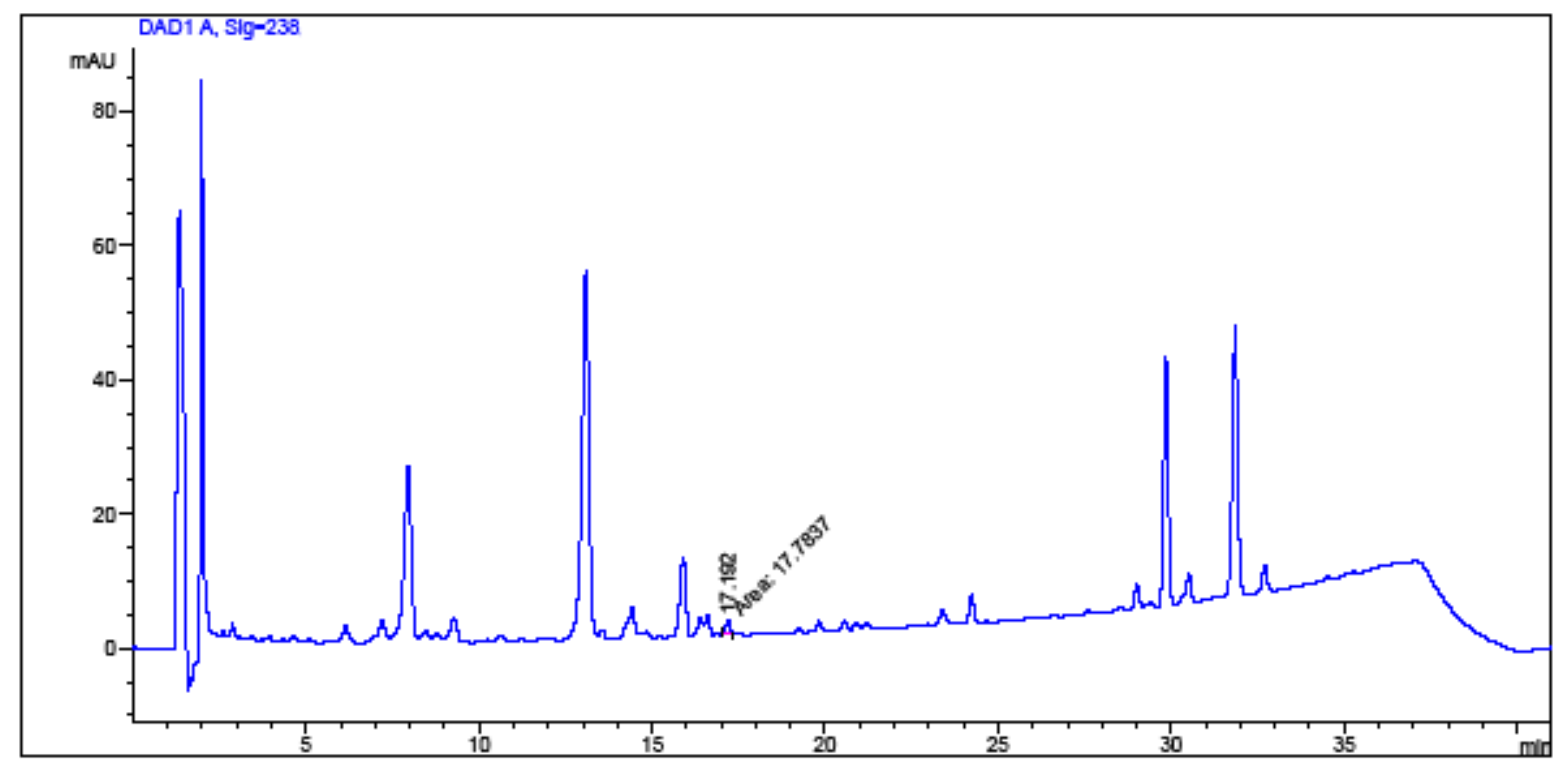

Figura 36: Cromatograma do extrato de floração de cianobactéria do estabelecimento C, coletado em setembro de 2007. Obtido conforme o gradiente descrito na Tabela 2, coluna Nucleosil C18, com tamanho de partícula de $5 \mathrm{um}, 250 \mathrm{~mm}$ de comprimento e 4,6 mm de diâmetro interno, comprimento de onda de $238 \mathrm{~nm}$ e fluxo de $1,5 \mathrm{~mL} \mathrm{~min}^{-1}$. Um pico com o mesmo tempo de retenção da microcistina-LR foi encontrado.

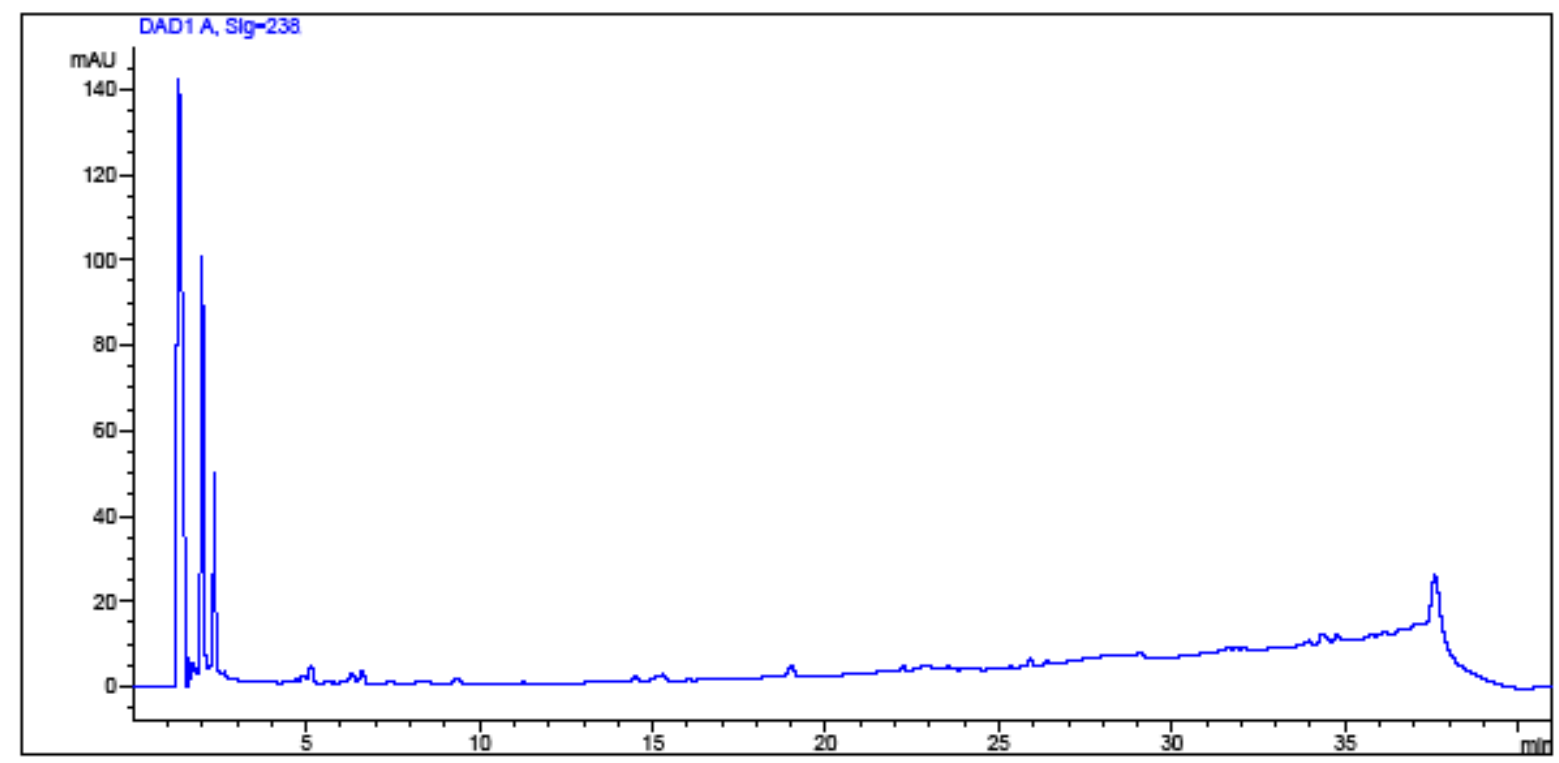

Figura 37: Cromatograma do extrato de floração de cianobactéria do estabelecimento $\mathrm{E}$, coletado em janeiro de 2008. Obtido conforme o gradiente descrito na Tabela 2, coluna Nucleosil C18, com tamanho de partícula de $5 \mathrm{um}, 250 \mathrm{~mm}$ de comprimento e 4,6 mm de diâmetro interno, comprimento de onda de $238 \mathrm{~nm}$ e fluxo de $1,5 \mathrm{~mL} \mathrm{~min}^{-1}$. Não foi encontrado nenhum pico com o mesmo tempo de retenção do padrão da microcistina-LR. 
Pode-se observar nas Figuras 31 e 35, cromatogramas dos extratos das amostras de florações de cianobactérias do estabelecimento $A$, coletadas em outubro de 2006 e setembro de 2007, respectivamente, que foi encontrado um pico no mesmo tempo de retenção do padrão da microcistina-LR, porém a concentração calculada utilizando os parâmetros da curva analítica y $=1,5888+21,849 x$, onde y é a área obtida no cromatograma da amostra, foi de $0,03 \mu \mathrm{g} \mathrm{mL}^{-1}$, e $0,01 \mu \mathrm{g} \mathrm{mL} \mathrm{L}^{-1}$, valores menores que o limite de detecção determinado no método validado $(0,1 \mu \mathrm{g}$ $\mathrm{mL}^{-1}$ ), e por se tratar de uma concentração muito pequena, o espectro de UV não foi processado pelo software Chemstation, portanto não foi possível nesses casos provar que esses picos são realmente da microcistina-LR. A Tabela 17 apresenta os resultados obtidos das análises das amostras de florações.

Tabela 17 - Resultados das análises das amostras de florações de cianobactérias.

\begin{tabular}{|c|c|c|c|c|}
\hline Estabelecimento & $\begin{array}{c}\text { Mês/ ano de } \\
\text { amostragem }\end{array}$ & $\begin{array}{c}\text { Área } \\
\left(\mu \mathbf{~ m L}^{-1}\right)\end{array}$ & $\begin{array}{c}\text { Concentração } \\
\boldsymbol{n}^{\mathbf{o}}\end{array}$ \\
\hline $\boldsymbol{A}$ & Outubro / 2006 & 2,3178 & $<\mathrm{LQ}$ & 31 \\
\hline $\boldsymbol{B}$ & Outubro / 2006 & 1,6871 & $<\mathrm{LD}$ & 32 \\
\hline $\boldsymbol{C}$ & Maio / 2007 & 8,1578 & $<\mathrm{LQ}$ & 33 \\
\hline $\boldsymbol{D}$ & Maio / 2007 & 28,6536 & 1,2 & 34 \\
\hline $\boldsymbol{A}$ & Setembro / 2007 & 1,9144 & $<\mathrm{LD}$ & 35 \\
\hline $\boldsymbol{C}$ & Setembro / 2007 & 17,7837 & 0,7 & 36 \\
\hline $\boldsymbol{E}$ & Janeiro / 2008 & zero & $<\mathrm{LD}$ & 37 \\
\hline
\end{tabular}




\section{5 - Conclusões}

O método analítico para determinação e quantificação da microcistina-LR presente em florações de cianobactérias coletadas na região do Alto Mogi, bacia hidrográfica do Mogi Guaçu, pode ser considerado validado, conforme resultados obtidos dentro dos critérios de aceitação propostos pela ANVISA (Agência de Vigilância Sanitária), em seu Guia para Validação de Métodos Analíticos e Bioanalíticos, de 2003.

\section{Considerações finais}

Os impactos ambientais e os problemas de saúde pública causados por florações de cianobactérias têm se mostrado cada vez mais freqüentes no Brasil e no mundo. Uma das causas observadas é o lançamento não controlado de efluentes, por isso se faz necessário a conscientização da população e de entidades comerciais, no sentido de controlar e solucionar essa problemática. Do ponto de vista analítico, observa-se um grande avanço com relação às técnicas instrumentais, embora a indisponibilidade de padrões e materiais certificados seja um obstáculo para os cientistas. Laboratórios privados e oficiais no Brasil se estruturam dentro do alto custo e da complexidade analítica para poderem oferecer o controle da qualidade das águas para abastecimento público, segundo parâmetros estabelecidos por órgãos oficiais.

Vale ressaltar que a continuação do monitoramento das pisciculturas e pesquepagues da região do Alto Mogi é de suma importância, visto que foram detectadas concentrações significativas da toxina microcistina-LR nas amostras de florações, coletadas nestes estabelecimentos. Faz-se necessário também, um estudo focado 
em outras toxinas provenientes de diferentes espécies de cianobactérias, causadoras de florações, pois apesar de não ter sido detectada a microcistina-LR em todas as amostras que evidenciavam ser potencialmente tóxicas, é possível observar por meio dos cromatogramas, que a incidência de picos no tempo de retenção próximo ao do padrão da microcistina-LR, pode ser um indicativo da presença de toxinas com características semelhantes às da mesma e que podem ser igualmente tóxicas, ou mais.

\section{7 - Referências Bibliográficas}

AGUIAR, D.G.; AZEVEDO, S.M.F.O. Ocorrência de diferentes cepas tóxicas de Microcystis aeruginosa em diversos corpos d'água brasileiros. In: $6^{a}$ REUNIÃO BRASILEIRA DE FICOLOGIA, 1993, Tramandaí/ Imbé, RS.

ALMEIDA, V.P. S. Detecção de microcistina através de inibição de proteína fosfatase (tipo 1), em condições controladas de crescimento de cianobactérias e em amostras ambientais de água. 2002. Dissertação (Mestrado) - Escola Superior de Agricultura Luís de Queiroz, Centro de Energia Nuclear na Agricultura, Universidade de São Paulo. Piracicaba, 2002.

AN, J. ; CARMICHAEL, W. W. Use of a colorimetric protein phosphatases inhibition assay and enzyme linked immunosorbent assay for the study of microcystins and nodularins. Toxicon, v. 32, p. 1495-1507, 1994.

AZEVEDO, S.M.F.O. Toxic cyanobacteria and the Caruaru tragedy. In: SIMPÓSIO DA SOCIEDADE BRASILEIRA DE TOXINOLOGIA, 1996, Recife, PE. Anais. Recife, PE, 1996. p. 83.

AZEVEDO, S.M.F.O.; EVANS, W.R.; CARMICHAEL, W.W.; NAMIKOSHI, M. First report of microcystins from a brazilian isolate of the cyanobacterium Microcystis aeruginosa. Journal Applied Phycology, v. 6, p. 261- 265, 1994.

BARCO, M.; LAWTON, L.A.; RIVERA, J.; CAIAXACH, J. Optimization of intracellular microcystin extraction for their subsequent análisis by high-performance liquid chromatography. Journal of Chromatography A, v. 1074, p. 23- 30, 2005. 
BELL, S.G.; CODD, G.A. Cyanobacterial Toxins and Human Health. Reviews In Medical Microbiology, v. 5, n. 4, p. 256- 264, 1994.

BOBEDA, C.R.R.; AZEVEDO, S.M.F.O. Análise quali-quantitativa da produção de toxinas em um "bloom" de Microcystis aeruginosa no Reservatório do Funil, Município de Resende, Rio de Janeiro. In: $6^{a}$ REUNIÃO BRASILEIRA DE FICOLOGIA, 1993, Tramandaí/Imbé, RS. Livro de resumos. 1993

BOTES, D.P.; KRUGER, H.; VILJOEN, C.C. Isolation and characteriza- tion of four toxins from the blue-green alga. Microcystis aeruginosa. Toxicon, v. 20, p. 945- 954, 1982.

BOTHA, N.; VAN DE VENTER, M.; DOWNING, T. G.; SHEPHARD, E. G.;

EHRINGER, M. M. The effect of intraperitoneally administered microcystin-LR on the gastrointestinal tract of Balb/c mice. Toxicon, v. 43, n. 3, p. 251- 254, 2004.

BRASIL. Ministério da Saúde. Fundação Nacional de Saúde - FUNASA. Portaria ${ }^{\circ}$ 1469, de 29 de dezembro de 2000. Cianobactérias tóxicas na água para consumo humano na saúde pública e processos de remoção em água para consumo humano. 2003. Disponível em: <http:/ / portal.saude.gov.br/portal/arquivos/pdf/ mnl_ciano_bacterias.pdf>. Acesso em: 15 ago. 2007.

BRASIL. Fundação Nacional de Saúde. Portaria n 1469/2000, de 29 de dezembro de 2000: aprova o controle e vigilância da qualidade da água para consumo humano e seu padrão de potabilidade. Diário Oficial da União, Brasília, DF, 2001. p.32.

BRASIL. Ministério da Saúde Agência Nacional de Vigilância Sanitária - ANVISA. Resolução RE $n^{\circ}$ 899, de 29 de maio de 2003. Guia para Validação de Métodos Analíticos e Bioanalíticos. Disponível em : <http// www.anvisa.gov.br>. Acesso em 15 junho de 2006.

BRASIL. Ministério da Saúde. Agência Nacional de Vigilância Sanitária - ANVISA. Portaria $\mathrm{n}^{\circ} 518$, de 25 de março 2004 . Estabelece os procedimentos e responsabilidades relativos ao controle e vigilância da qualidade da água para consumo humano e seu padrão de potabilidade, e dá outras providências. Diário Oficial da República Federativa do Brasil, Brasília, DF, 26 março 2004. Seção 1.

BURY, N.R.; FLIK, G.; EDDY, F.B.; CODD, G.A. The effects of cyanobacterial toxin microcystin-LR on $\mathrm{Ca}^{+2}$ transport and $\mathrm{Na}^{+} / \mathrm{K}^{+}$-ATPase in tilapia gills. The Journal of Experimental Biology, v. 199, p. 1319- 1326, 1996. 
CARMICHAEL, W.W. Status report on planktonic cyanobacteria (blue green algae) and their toxins. Cincinnati: U.S. Environmental Protection Agency, 1992. 149p.

CARMICHAEL, W.W. Cyanobacteria Secondary Metabolites - The Cyanotoxins. Journal Applied Bacteriology, v. 72, p. 445- 459, 1992.

CARMICHAEL, W.W.; AZEVEDO, S.M.F.O.; MOLICA, R.J.R.; JOCHIMSEN, E.M.; LAU, S.; RINCHART, K.L.; SHAW, G.R.; EAGLESMAM, G.K. Human fatalities from cyanobacteria: chemical and biological evidence for cyanotoxins. Environmental Health Perspectives, v. 109, p. 663- 668, 2001.

CHEN, G.; YU, G.; WEI, G. Studies on microcystin contents in different drinking water in highly endemic area of liver cancer. Chung Hua Yu Fang I Hsueh Tsa Chih, v. 30, n. 1, p. 6- 9, 1996.

CHORUS I.; MUR L. Preventive Measures. In: Chorus I, Bartram J, editors. Toxic Cyanobacteria in Water. London: E\&FN Spon; 1999. 432p. (Book Reviews).

CHU, F. S.; HUANG, X.; WEI, R. D. ; CARMICHAEL, W. W. Production and characterization of antibodies against microcystins. Applied Environmental Microbiology, v. 55, p. 1928- 1933, 1989.

CODD, G.A.; BELL, S.G.; BROOKS, W.P. Cyanobacterial toxins in water. Revista Brasileira de Biologia, v. 59, p. 361- 376, 1989.

COLLINS, C.H.; BRAGA, G.L.; BONATO, P.S. Introdução a métodos cromatográficos. Campinas: UNICAMP, Campinas, 1997.

COMITÊ DE BACIA HIDROGRÁFICA DO MOGI GUAÇU et al. Diagnóstico da bacia hidrográfica do rio Mogi Guaçu: Relatório Zero. São Paulo: CBH-MOGI, 1999. 240 p.

COYLE, S.M. ; LAWTON, L.A. Development of an extraction procedure for the quantitative analisys of microcystin in cianobacterial cells. Phycologia, v. 35, p. 57$61,1996$.

DEBERDT, G. L. B. Estudo de cianobactérias em reservatório com elevado grau de trofia (Reservatório de Salto Grande - Americana - SP). São Carlos, 2002. 207f. Tese (Doutorado) - Escola de Engenharia de São Carlos, Universidade de São Paulo. 
DEGANI, A.L.G.; CASS, Q.B.; VIEIRA, P.C. Cromatografia: um breve ensaio. Química Nova na Escola, v. 7, p. 21- 25, 1997.

EDWARDS, C.; LAWTON, L.A.; COYLE, S.M.; ROSS, P. Laboratory-scale purification of microcystins using flash chromatography and reversed-phase highperformance liquid chromatography. Journal of Chromatography A, v. 734, n. 1, p. 163- 173, 1996.

ELDER, G.H.; HUNTER, P.R.; CODD, G.A. Hazardous freshwater cyanobacteria (blue-green algae). The Lancet, n. 341, p. 1519- 1520, 1993.

ELER, M.N.; CECCARELLI, P. S.; BUFON, A.G.M. Mortandade de peixes em viveiros de piscicultura. In: $6^{\circ}$ ENCONTRO DE ECOTOXICOLOGIA e $3^{a}$ REUNIÃO DA SETAC LATINO AMERICANA. São Carlos, SP, 3-6 de setembro de 2000.

ELER, M. N. Efeito da densidade de estocagem de peixes e do fluxo de água na qualidade de água e na sucessão do plâncton em viveiros de piscicultura. São Carlos, 2000. 258f Dissertação (Mestrado) - Escola de Engenharia de São Carlos, Universidade de São Paulo, São Carlos, 2000.

FALCONER, I.R.; BURCH, M.D.; STEFFENSEN, D.A.; CHOICE, M.; COVERDALE, O.R. Toxicity of the blue-green alga (cyanobacterium) Microcystis aeruginosa water to growing pigs, as an animal model for human injury and risk assessment.

Environmental Toxicology Water Quality, v. 9, p. 131- 139, 1994.

FALCONER, I. R.; HUMPAGE, A. R. Health risk assessment of Cyanobacterial (Blue-Green Algal) toxins in drinking water. International Journal of Environmental Research and Public Health, v. 2, n. 1, p. 43- 50, 2005.

FERREIRA, Luciana. Pallone. Hespanholo. Remoção da biomassa algal e determinação da concentração de microcistina pelo método ELISA em ensaios de coagulação, sedimentação, filtração e adsorção, 2004. 114f. Dissertação (Mestrado) - Escola de Engenharia de São Carlos, Universidade de São Paulo, São Carlos, 2004.

FIGUEIREDO, D. R.; AZEITEIRO, U. M.; ESTEVES, S. M.; GONÇALVES, F. J.; PEREIRA, M. J. Microcystin producing blooms - a serious global public health issue. Ecotoxicology and Environmental Safety, v. 9, n. 2, p. 151- 163, 2004. 
FISCHER, W. J.; DIETRICH, D. R. Pathological and biochemical characterization of microcystin-induced hepatopancreas and kidney damage in carp (Cyprinus carpio). Toxicology and Applied Pharmacology, v. 164, n. 1, p. 73- 81, 2000.

FRITZ, J.S.; MACKA, M. Review Solid-phase trapping of solutes fo further chromatographic or electrophoretic analysis. Journal of Chromatography A. v. 902, p. 137- 166, 2000.

FUJIKI, $\mathrm{H}$. Is the inhibition of the protein phosphatase 1 and $2 \mathrm{~A}$ activities a general mechanism of tumor promotion in human cancer development? Molecular

Carcinogenesis, n. 5, p. 91- 94, 1992.

GUPTA, S. WHO guidelines for drinking water quality, 2. ed., Geneva , World Health Organization, 1998.

HARADA, K.; SUZUKI, M.; DAHLEM, A.M.; BEASLEY, V.R.; CARMICHAEL, W.W.; RINEHART, K.L. Improved methods for purification of toxic peptides produced by cyanobacteria. Toxicon, v. 26, n. 5, p. 433-439, 1988.

HARADA, K.; OGAWA, K.; KIMURA, Y.; MURATA, H.; SUZUKI, M.; THORN, P.M.; EVANS, W.R.; CARMICHAEL, W.W. Microcystins from Anabaena flos- aquae NRC 525-17. Chemical Research Toxicology, v. 4, p. 535, 1991.

HARADA, K.; MURATA, H.; QIANG, Z.; SUZUKI, M.; KONDO, F. Mass spectrometric screening method for microcystins in cyanobacteria. Toxicon, v. 34, n. 6, p. 701710, 1996.

HART, J.; FAWELL, J.K.; CROLL, B. The fate of both intra- and extracellular toxins during drinking water treatment. Water Supply, v. 16, p. 611-616, 1998.

IMANISHI, S.; HARADA, K. Proteomics approach on microcystin binding proteins in mouse liver for investigation of microcystin toxicity. Toxicon, v. 43, n. 6, p. 651- 659, 2004.

JOCHIMSEN, E.M.; CARMICHAEL, W.W.; AN, J.; CARDO, D.; COOKSON, S.T.; HOLMES, C.E.M.; ANTUNES, M.B.C.; MELO-FILHO, D.A.; LYRA, T.M.; BARRETO, V.; AZEVEDO, S.M.F.O.; JARVIS, W.R. Liver failure and death following exposure to microcystin toxins at a hemodialysis center in Brazil. The New England Journal of Medicine, v. 36, p. 373- 378, 1998. 
KONDO, F.; HARADA, K. Mass spectrometric analyses of cyanobacterial toxins. Journal of the Mass Spectrometry Society of Japan, v. 44, n. 3, p. 355- 376, 1996.

KOTAK, B. G.; SEMALULU, S.; FRITZ, D. L.; PREPAS, E. E.; HRUDEY, S. E.; COPPOCK, R. W. Hepatic and renal pathology of intraperitoneally administered microcystin-LR in rainbow trout (Oncorhynchus mykiss). Toxicon, v. 34, n. 5, p. 517525, 1996.

KUIPER- GOODMAN, T.; GUPTA, S.; CAOMBLEY, H.; THOMAS, B.H. Microcystins in drinking water: Risk, assessment and derivation of a possible guidance value for drinking water. In: PROCEDURE OF TOXIC CYANOBACTERIA - A GLOBAL PERSPECTIVE. Adelaide, Australia, Australian Center of Water Quality Research, 1994.

LANÇAS, F. M.; BARRIONUEVO, W. R. Comparison Among Three Different extraction Techniques (LLE,SPE,SPME) for Pyrethroid Analysis in River Water. Journal Of Environmental Science And Health Part B - Pesticides, Food And Agricultural Wastes, v. 69, p. 123-128, 2002.

LANKOFF, A.; CARMICHAEL, W. W.; GRASMAN, K. A.; YUAN, M. The uptake kinetics and immunotoxic effects of microcystin-LR in human and chicken peripheral blood lymphocytes in vitro. Toxicology, v. 204, n. 1, p. 23- 40, 2004.

LAWRENCE J.F., MENARD C. Determination of microcystins in blue-green algae, fish and water using liquid chromatography with ultraviolet detection after sample clean-up employing immunoaffinity chromatography. Journal Chromatography $A, n$. 922, p. 111-117, 2001.

LAWTON, L.A.; EDWARDS, C.; BEATTIE, K.A.; PLEASANCE, S.; DEAR, G.J.; CODD, G.A. Isolation and characterization of microcystins from laboratory cultures and environmental samples of Microcystis aeruginosa and from an associated animal toxicosis. Natural Toxins, v. 3, p. 50, 1995.

LAWTON, L.A.; CORNISH, B.J.P.A.; MACDONALD, A.W.R. Removal of cyanobacterial toxins (microcystins) and cyanobacterial cells from drinking water using domestic water filters. Pergamon, v. 32, n. 3, p. 633- 638, 1998.

LI, X. Y.; CHUNG, I. K.; KIM, J. I.; LEE, J. A. Subchronic oral toxicity of microcystin in common carp (Cyprinus carpio L.) exposed to Microcystis under laboratory

conditions. Toxicon, v. 44, n. 8, p. 821-827, 2004. 
LORENZI, Adriana Sturion Abordagens moleculares para detectar cianobactérias e seus genótipos produtores de microcistinas presentes na represa de Billings e Guarapiranga. 2004. 92f. Dissertação (Mestrado) - ESALQ, Centro de Energia Nuclear na Agricultura, Universidade de São Paulo, Piracicaba, 2004.

MAAGD, P.G.J.; HENDRIKS, A.J.; SEINEN, W.; SIJM, D.T.H.M. Water Research, v. 33, p. 677, 1999.

McDERMOTT, C. M.; NHO, C. W.; HOWARD, W.; HOLTON, B. The cyanobacterial toxin, microcystin-LR, can induce apoptosis in a variety of cell types. Toxicon, v. 36, n. 12, p. 1981-1996, 1998.

MACKINTOSH, C.; BEATTIE, K. A.; KLUMPP, S.; COHEN, P.; CODD, G. A.; Cyanobacterial microcystin-LR is a potent and specific inhibitor of protein phosphatases 1 and 2A from Both Mammals and Higher Plants. Febs Letters, v. 264, p. 187- 192, 1990.

MACKINTOSH, C.; MACKINTOSH, R.W.; The inhibition of protein phosphatases by toxins: implications for health and an extremely sensitive and rapid bioassay for toxin detection. In: CODD, G. A.; JEFFERIES, T. M. ; KEEVIL, C. W.; POTTER, E. (Eds.). Detection methods for cyanobacterial toxins. Cambridge: The Royal Society of Chemistry, p. 90- 99.

MAGALHÃES, V. F.; MARINHO, M. M.; DOMINGOS, P.; OLIVEIRA, A. C.; COSTA, S. M.; AZEVEDO, L. O.; AZEVEDO, S. M. F. O. Microcystins (cyanobacteria hepatotoxins) bioaccumulation in fish and crustaceans from Sepetiba Bay (Brasil, RJ). Toxicon, v. 42, n. 3, p. 289- 295, 2003.

MAGALHÃES V.F.; SOARES, R.M.; AZEVEDO, S.M.F. Microcystin contamination in fish from the Jacarepaguá Lagoon (Rio de Janeiro, Brasil): ecological implication and human health risk. Toxicon, v. 39, p. 1077- 1085, 2001.

MAGALHÃES, V.F.; OLIVEIRA, A.C.; MARINHO, M.M.; DOMINGOS, P.; COSTA, S.M.; AZEVEDO, L.O.; AZEVEDO, S.M.F.O. Detecção de Microcistinas (Hepatotoxinas de Cianobactérias) na Água, Séston e Pescado da Baia de Sepetiba (RJ). In: $6^{\circ}$ ECOTOX, 2000, São Carlos, SP. Livro de Resumos $6^{\circ}$ Ecotox: São Carlos:95p, 2000.

MALBROUCK, C.; TRAUSCH, G.; DEVOS, P.; KESTEMONT, P. Hepatic accumulation and effects of microcystin-LR on juvenile goldfish Carassius auratus $L$. Comparative Biochemistry and Physiology - Part C, v. 135, n. 1, p. 39- 48, 2003. 
MARTIN, C. ; SIVONEN, K.; MATERN, U. ; DIERSTEIN, R.; WECKESSER, J. Rapid purification of the peptide toxins microcystin-LR and nodularin. FEMS

Microbiology Letters, v. 56, p.1-2, 1990.

MAJORS, R. E. LC-GC - An overview of sample preparation. Intl v. 9, p.16- 20, 1991.

MERILUOTO, J.A. \& LEM, S. Cyanotoxins: sampling, sample processing and toxin uptake. Chapter 21. In Hudnell, H.K. (ed.): Proceedings of the Interagency, International Symposium on Cyanobacterial Harmful Algal Blooms. Advances in Experimental Medicine \& Biology. p. 467-483, 2007.

MILUTINOVIC, A.; ZIVIN, M.; ZORC-PLESKOVIC, R.; SEDMAK, B.; SUPUT, D. Nephrotoxic effects of chronic administration of microcystins -LR and -YR. Toxicon, v. 42, n. 3, p. 281- 288, 2003.

MOHAMED, Z. A.; CARMICHAEL, W. W.; HUSSEIN, A. A. Estimation of microcystins in the freshwater fish Oreochromis niloticus in a Egyptian fish farm containing a microcystis bloom. Environmental Toxicology, v. 18, n. 2, p. 137-141, 2003.

MOHAMED, Z. A.; HUSSEIN, A. A. Depuration of microcystins in tilapia fish exposed to natural populations of toxic cyanobacteria: A laboratory study. Ecotoxicology and Environmental Safety, v. 63, p. 424- 429, 2006.

MSAGATI, T. A. M.; SIAME, B. A.; SHUSHU, D. D. Evaluation of methods for the isolation, detection and quantification of cyanobacterial hepatotoxins. Aquatic Toxicology, v. 78, n. 4, p. 382- 397, 2006.

NAMIKOSHI, M.; RINEHART, K.L.; SAKAI, R.; STOTTS, R.R.; DAHLEM, A.M.; BEASLEY, V.R.; CARMICHAEL, W.W.; EVANS, W.R. Isolation and structures of microcystins from a cyanobacterial water bloom .Journal Organic Chemistry, v. 57, p. 866, 1992.

NAMIKOSHI, M.; YUAN, M.; SIVONEN, K.; CARMICHAEL, W.W.; RINEHART, K.L.; ROUHIAINEN, L.; SUN, F.; BRITTAIN, S.; OTSUKI, A. Seven new microcystins possessing two L-glutamic acid units, isolated from Anabaena sp. strain 186.

Chemical Research Toxicology, v. 11, p. 143, 1998. 
NOBRE, A. C.; NUNES-MONTEIRO, S. M.; MONTEIRO, M. C.; MARTINS, A. M.; HAVT, A.; BARBOSA, P. S.; LIMA, A. A.; MONTEIRO, H. S. Microcystin-LR promote intestinal secretion of water and electrolytes in rats. Toxicon, v. 44, n. 5, p. 555- 559, 2004.

PINHO, G. L. L.; ROSA, C. M.; MACIEL, F. E.; BIANCHINI, A.; YUNES, J. S.; PROENÇA, L. A. O.; MONSERRAT, J. M. Antioxidant responses and oxidative stress after microcystin exposure in the hepatopancreas of na estuarine crab species.

Ecotoxicology and Environmental Safety, v. 61, p. 353- 360, 2005.

RABERGH, C. M. I.; BYLUND, G.; ERIKSSON, J. E. Histopathological effects of microcystin-LR, a cyclic peptide toxin from the cyanobacterium (blue-green alga) Microcystis aeruginosa, on common carp (Cyprinus carpio L.). Aquatic Toxicology, v. 20, p. 131- 145, 1991.

RIBANI, M.; BOTTOLI, C. B. G.; COLLINS, C. H.; JARDIM, I. C. S. F.Validação em métodos cromatográficos e eletroforéticos. Química Nova ,v. 27, n. 5, p. 771- 780, 2004.

RIBEIRO, L.P.; MIRANDA, M.O.T.; LIMA, L.C.; HOLANDA, E.D. Aquacultura empresarial. Informe Agropecuário, Belo Horizonte, v. 21, n. 203, p. 5- 9, 2000.

RIVASSEAU, C.; MARTINS, S.; HENNION, M.C. Determination of some physicochemical parameters of microcystins (cyanobacterial toxins) and trace level analysis in environmental samples using liquid chromatography. Journal of Chromatography A, v. 799, p. 155- 169, 1997.

ROSENTHAL, H. Aquaculture and the environment. World Aquaculture,v. 25, n. 2, p. 4- 11, 1994.

RUANGYUTTIKARN, W.; MIKSIK, I.; PEKKOH, J. Reversed-phase liquid chromatographic-mass spectometric determination of microcystin-LR in cyanobacteria blooms under alcaline conditions. Journal of Chromatography $\mathbf{B}, \mathrm{v}$. 800, p. 315- 319, 2004.

SANO, T.; NOHARA, K.; SHIRAISHI, F.; KAYA, K. A method for micro-determination of total microcystin content in waterblooms of cyanobacteria (blue-green algae).

International Journal of Environmental Analytical Chemistry, v. 49, n. 3, p. 163170, 1992. 
SANT'ANNA C. L; AZEVEDO M.T.P. Contribution to the knowledge of potentially toxic Cyanobacteria from Brazil. Nova Hedwigia, v. 71, n. 3- 4, p. 359- 385, 2000.

SCOTT, R.P.W. In: Silica Gel and Bonded phases: their production, properties and use in LC. SCOTT, R.P.W.;SIMPSON, C.F. (Eds.) New York: John Wiley and Sons, 1993. p.1- 176.

SICINSKA. P.; BUKOWSKA, B.; MICHALOWICZ, J.; DUDA, W. Damage of cell membrane and antioxidative system in human erythocytes incubated with microcystin-LR in vitro. Toxicon, v. 47, n. 4, p. 387- 397, 2006.

SOARES, R. M.; MAGALHAES, V. F.; AZEVEDO, S. M. Accumulation and depuration of microcystins (cyanobacteria hepatotoxins) in Tilapia rendalli (Cichlidae) under laboratory conditions. Aquatic Toxicology, v. 70, n. 1, p. 1- 10, 2004.

TEKEL, J.; HATRIK, S. Review Pesticide residue analyses in plant material by chromatographic methods: clean-up procedures and selective detectors. Journal of Chromatography A, v. 754, p. 397- 410, 1996

TENCALLA, F.G.; DIETRICH, D.R.; SCHLATTER, C. Toxicity of Microcystis aeruginosa peptide toxin to yearling rainbow trout (Oncorhynchus mykiss). Aquatic Toxicolology, n. 30, p. 215- 224, 1994.

WATZIN, M.C.; ROGALUS, M. K. Evaluation of sampling and screening techniques for tiered monitoring of toxic cyanobacteria in lakes. Harmful Algae, v. 7, p. 504$514,2008$.

WHO. Guidelines for Drinking Water Quality, 2 ed. Geneva: World Health Organization, 1998. v.2, p. 13-14.

YUAN, M.; CARMICHAEL, W. W. Detection and analysis of the cyanobacterial peptide hepatotoxins microcystin and nodularin using SELDI-TOF mass spectrometry.Toxicon, v. 44, n. 5, p. 561- 570, 2004.

ZAGATTO, P.A. Evaluation ecotoxicologique dureservoir Guarapiranga, SP, Bresil, en relation avec le problème des algues toxiques et des algicides. 1995. 86f. Tese de Doutorado - Université de Metz, France, 1995. 
ZAGATTO, P.A.; ARAGÃO, M. A. Toxicidade de cianofíceas (algas azuis) do reservatório do Guarapiranga,SP. In: $2^{\circ}$ ENCONTRO DE ECOTOXICOLOGIA, Cassino, Rio Grande, RS, 55p, 1992.

ZHANG, L.; PING, X.; YANG, Z. Detemination of microcystin-LR in suface water using high-performance liquid chromatography/tandem electrospray ionization mass detector, Talanta, v. 62, p. 193- 200, 2003.

ZHANG, J.; ZHANG, H.; CHEN, Y. Sensitive apoptosis induced by microcystins in the crucian carp (Carassius auratus) lymphocytes in vitro. Toxicology in Vitro, v. 20, p. 560- 566, 2006. 